Florida International University FIU Digital Commons

$11-18-1993$

\title{
An analysis of the role of Latin American labor unions under democratization: the Argentine CGT's role under president Carlos Menem
}

Giselle Audrey De Bruno

Florida International University

DOI: $10.25148 /$ etd.FI14062218

Follow this and additional works at: https://digitalcommons.fiu.edu/etd

Part of the International and Area Studies Commons

\section{Recommended Citation}

De Bruno, Giselle Audrey, "An analysis of the role of Latin American labor unions under democratization: the Argentine CGT's role under president Carlos Menem" (1993). FIU Electronic Theses and Dissertations. 3013.

https://digitalcommons.fiu.edu/etd/3013 
FLORIDA INTERNATIONAL UNIVERSITY

Miami, Florida

AN ANALYSIS OF THE ROLE OF LATIN AMERICAN LABOR UNIONS UNDER DEMOCRATIZATION:

THE ARGENTINE CGT'B ROLE UNDER PRESIDENT CARLOS MENEM

A thesis submitted in partial satisfaction of the requirements for the degree of MASTER OF ARTS

IN

INTERNATIONAL STUDIES

by

Giselle Audrey De Bruno 
To: Dean Arthur W. Herriott

school of Arts and Sciences

This thesis, written by Giselle Audrey De Bruno, and entitled AN ANALYSIS OF THE ROLE OF LATIN AMERICAN LABOR UNIONS UNDER DEMOCRATIZATION: THE ARGENTINE CGT'S ROLE UNDER PRESIDENT CAKLOS MENEM, having been approved in respect to style and intel lectual. content, is referred to you for judgement.

We have read this thesis and recommend that it be approved.

Mark D. Szuchman

Maria F. Willumsen

Eduardo A. Gamarra, Majox mroferset

Date of Defense: November 19, 1993

The thesis of Giselle Audrey De Bruno is approved.

Dean Arthur W. Herriott

College of Arts and sciences

Dr. Richard L. Campbell

Dean of Graduate studies 
- COPYRIGHT 1993 by Giselle Audrey De Bruno

All rights reserved

iii 
I dedicate this thesis to the two most important men in my life: my father and my fiancé Mike. Without their help, support, and most of all love, the completion of this work would not have been possible. 
ACRNOWLEDGMENTS

I wish to thank the members of my committee for their helpful comments, and especially my major professor, Dr. Eduardo Gamarra, for his support and confidence.

I am very appreciative of people who sent me materials from Argentina, such as the faculty from the catholic University of córdoba, especially president rather Moreno, Graciela Pilnik, Dr. Mooney, and Miss Reid. I also wish to thank Miguel Danielián, head of the supreme Justice Library, my parents, who spent many hours at book stores in Argentina, and organizations that answered my requests for information such as La Embajada Argentina en Washington, ILO, the U.s. Chamber of Commerce and the Development GAP.

A very special thanks goes to Dr. Donald Klingner for his intelligent comments on my thesis and valuable suggestions. In addition I thank Valerie De Bruno, stephanie Weppler, and Gary Roberts for their useful comments on my proposal.

The last, though most important, expression of my gratitude goes to my fiancé Mike and my father, who gave me their love and support. Mike read every word of this thesis at one point or another, and my father patiently classified newspapers and other material, and to my mother and sisters, who indirectly coexisted with the manuscript in many ways. of course, any responsibility lies solely with the author. 


\title{
AN ANALYSIB OF THE ROLE OF LATIN AMERICAN LABOR UNIONS UNDER DEMOCRATIZATION:
}

THE ARGEMTINE CGT'B ROLE UNDER PRESIDENT CARLOS MENEM

\author{
by \\ Giselle Audrey De Bruno \\ Florida International University, 1993 \\ Miami, Florida \\ Professor Eduardo Gamarra, Major Professor
}

Labor unions have played an important role in Latin American society. This is particularly true in Argentina, where the labor union movement gained strength in 1946 under the populist government of Juan Domingo Perón. When Carlos Menem, from the Peronist party, assumed presidency in 1989, the CGT, Argentina's labor confederation, expected traditional populism to return. Instead, Menem abandoned populism and aligned with the conservative right to implement a neoliberal agenda.

This thesis explores the processes by which Argentine labor unions lost strength during the dual processes of democratization and market reforms. BY analyzing the CGT since Menem become president, this study attempts to explain the role of labor unions under democracy, and the relationship between organized labor and government in the context of economic reforms and political transformation. Furthermore, this thesis argues that the decline of the cGT resulted from the implementation of neoliberal reforms. 


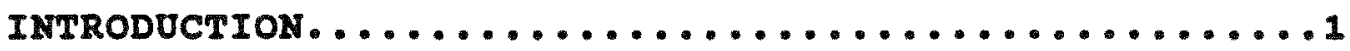

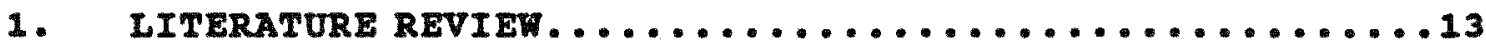

2. THE ECONOMIC REFORMS..........................4

3. MENEM AND THE CGT-COAPTATION AND CONTROL............75

4. THE CGT AND ITS STRUGGLE FOR INSTITUTIONAL

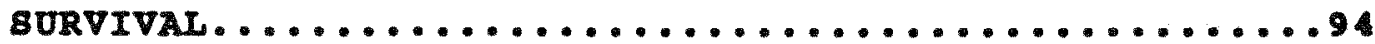

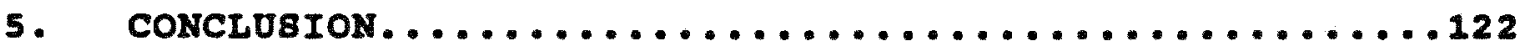

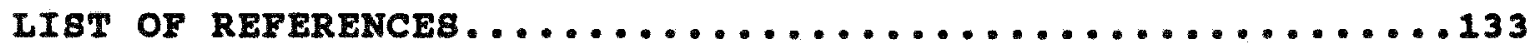

APRENDIXES ......................................... 
AN ANALYSIS OF THE ROLE OF LATIN AMERICAN LABOR UNIONS UNDER DEMOCRATIZATION ${ }^{1}$ : THE ARGENTINE CGT'S ROLE UNDER PRESIDENT CARLOS MENEM

I. INTRODUCTION

Labor unions have an important place in Latin American society, especially under populist ${ }^{2}$ governments. This is particularly true of Argentina, where the labor union movement gained considerable strength under the 1946 populist government of Juan Domingo Perön. First as Director of the Department of Labor in $1943,,^{3}$ and then as president for two

'In the return to democracy, "there are two moments in the transition process: an initial one related to implementing the more institutional version of democracy" and a second one known as "democratization." This study will use the term "democratization" to indicate the period of democratic life in Latin American countries that came after the "initial period of democracy." Juan Carlos Torres, "América Latina. Governing Democracies in Hard Times," (Paper presented at "IPSA XV congress section IIIs: The Political Correlates of Adjustment Policies," Buenos Aires, 1992).

${ }^{2}$ Spalding defines populism as "a political movement opposed to the status quo and supported by the mass of the urban working class and sometimes the peasantry as well as non working class elements. Politicians form the ruling class or petty bourgeoisie lead populist movements that despite rhetoric to the contrary, serve the class aims of these politicians. It is nationalistic in content and thus may involve real or potential conflict at the international leve1." In several countries populism came as a co-optive labor mechanism during the Great Depression. Howard Spalding, organized Labor in Latin America. Historical case studies of Workers in Dependent Societies (New York: Harper Torch Books, 1977), 151.

${ }^{3} \mathrm{~A}$ turning point in Perön's history, as correctly mentioned in Peter Ranis' book, was the meat packers' strike of 1943. From the Ministry of War, Perón intervened in favor of the workers. This launched him into the position at the Ministry of Labor, which brought him an unconditional support from the labor class. Peter Ranis, Argentine Workers: Peronism and contemporary class consciousness (Pittsburgh: University of Pittsburgh Press, 1992), 18. 
consecutive terms (1946-1955), Perón campaigned against the "exploitation of man by his fellow man," and the "dehumanization of capital" in a non-Marxist context, stressing the need to avoid class conflict. ${ }^{4}$

Perón's denunciation of the privileged Argentine landowner oligarchy, who had refused the demands of labor for years, established the basis for a country "redefined in terms of the social realm of civil society."5 Based on the support of the working class, who had "for the first time... an ardent supporter in the government," 6 Perón created a new political party: the Peronists. He amalgamated the different factions existing in the labor movement prior to 1940 s into one centralized labor confederation: the confederación General del Trabajo (CGT).

The CGT gained strength under Perón. An "extensive social welfare network was in place operated through the Ministry of Labor and Social Welfare, the Fundación Eva Perón, and the unions themselves."7 In 1943, only 20 percent of the urban labor force were organized, whereas under Perón unionization increased to 30.5 percent in 1948 , and to 42.5

${ }^{4}$ Ibid., 20.

SDaniel James, Resistance and Integration. Peronism and the Argentine Working Class, 1946-1976 (Cambridge: Cambridge University Press, 1988), 10.

${ }^{6}$ Howard Wiarda and Harvey Kline, eds., Latin American Politics and Development (Boulder, CO: Westview Press, 1990), 193 .

${ }^{7}$ James, Resistance and Integration, 11. 
percent in $1954 .^{8}$ From 1946 to 1951 , total union membership increased from 520,000 to $2,344,000$ members; a large number of state employees were unionized for the first time, and the majority of the manufacturing industries enjoyed a 50 to 70 percent unionization rate. 9 Perón implemented much of the legislation labor had demanded for a decade, such as maternity leave, sick leave, vacations, and the global system of collective bargaining and minimum wage. ${ }^{10}$

A majority of Perón's legislation remains today. Perón's impact on the labor movement continues to be an important part of contemporary Argentina. Even though the CGT suffered several setbacks during the years of antipopulism and military dictatorship, it retains a significant role. In Authoritarian and Democrats, Aldo Vacs argues that Argentina's democratic stability depends on the ability of governments to consider labor demands. He writes:

They [government] can try to promote the application of orthodox economic policies, but they cannot [emphasis added] ignore popular demands for redistribution, especially in a country such as Argentina, where trade unions are extremely organized and powerful."1

$$
\begin{aligned}
& { }^{8} \text { Ibid., } 8 . \\
& { }^{9} \text { Ibid., } 9 . \\
& { }^{10} \text { Spalding, organized Labor, } 164 .
\end{aligned}
$$

${ }^{11}$ Aldo Vacs, "Authoritarian Breakdown and Redemocratization in Argentina," in Authoritarians and Democrats. Regime Transition in Latin America, eds. James $M$. Malloy and Mitchell A. Seligson (Pittsburgh: University of Pittsburgh Press, 1987), 36-7. 
Argentina returned to democracy in 1983, after a decade of military dictatorship. Raúl Alfonsin, from the $U C R^{12}$ and the first president after the transition, was unable to solve Argentina's economic crisis and resigned before his term ended. In the 1989 Presidential elections, Carlos Saúl Menem, from the Peronist party, won with 47 percent of the votes against UCR candidate Eduardo Angeloz.

Menem's victory was a festive occasion for all Peronists, and especially for the CGT. After all, the CGT grew under Perón and was linked to the Peronist party. To the surprise of the CGT, Menem's government, which had proclaimed itself to be Peronist, abandoned Populism and aligned with the conservative right. Measures to open, privatize, and deregulate the economy followed a market place logic which conveniently displaced labor. According to one analyst: "The Menem administration's 'productive revolution' has replaced traditional populism not only by embracing representative democracy but also by distancing itself from Keynesian-based public policies."13

The implementation of economic reforms impacted labor and the CGT. As with other Latin American countries and

${ }^{12}$ Argentina's two most important political parties are the Peronist party and the Union Civica Radical (UCR), a middle class party. For more on Argentina's political parties see scott Mainwaring, "Political Parties and Democratization in Brazil and the Southern Cone," Comparative Politics (October, $1988): 91-120$.

${ }^{13}$ Ranis, Argentine Workers, 210. 
industrialized nations, unions lost power and influence under neoliberal reforms. In this thesis, the CGT's loss of political and economical power will be defined as: (1) loss of internal unity, (2) loss of capacity to organize collective pressure to alter the labor market, (3) loss of membership and revenue from membership dues, and (4) an inability to successfully use strikes to oppose neoliberal reforms.

Menem's neoliberal agenda included several elements of the so-called Washington Consensus, ${ }^{14}$ such as:

extensive reforms of the state (privatization of publicsector enterprises, fiscal reforms, severe retrenchment in compensatory social spending and elimination of subsidies to consumption and 'inefficient' producer interests, etc.); 'getting the prizes right' with a priority given to maintenance of macroeconomic equilibrium; sweeping market-oriented reforms (deregulation and de-monopolization of the private sector, flexibilization of labor markets, etc.); and competitive reinsertation in the world-economy (trade liberalization, promotion of foreign investment, etc.). ${ }^{15}$

Privatization meant a reduction of the work-force in the highly unionized public sector and an increase in the informal sector, diminishing union membership. As a consequence of the reforms, the CGT split into those who supported Menem and those who did not, undermining its unity.

The purpose of this thesis is to explore the processes by

${ }^{14}$ The Washington consensus is the term used to denote the neoliberal measures pushed by the Bush administration to reform Latin American economies.

${ }^{15}$ William Smith, "Neoliberal Restructuring and New Democracies in Latin America," North South Issues (May 1992):1. Also see John Williamson, political Economy and International Money: Selected Essays, ed. Luis Milner (New York: New York University Press, 1987). 
which labor unions lost strength during the dual processes of democratization and market reforms in Argentina. By analyzing the decline of the CGT since President Carlos Menem took office in 1989, this study will attempt to explain the role of labor unions under democracy, and the relationship between organized labor and government in the context of economic austerity, stabilization, and political transformation.

To explain the decline of labor movements, this study examines not only the CGT organization and its relations with the state and the rank and file, but also the broader international environment. Problems of leadership and governability will also be addressed. The thesis will argue that the decline of the CGT resulted from the implementation of Menem's neoliberal agenda of displacing labor and putting the market at the core of his political project. My principal hypothesis is that the implementation of structural adjustment and reforms has required both a weakened labor union organization and a government capable of controlling labor. III. SIGNIFICANCE OF PROPOSED RESEARCH

Since the 1980s, when Latin American countries elected democratic governments after the transition from military dictatorship, political scientists have attempted to explain the process of transition and the viability of stable democracies. The complexity of democratization called for new theories to explain not only the type of emerging democracy, but the role of social and political actors.

Latin American democratization literature broadly 
describes the process of transition and unfolding democracies. Most studies recognize that labor unions (and civil society in general) declined in the context of economic stabilization. Yet few studies focus on the specific processes involving social actors and institutions, ${ }^{16}$ especially labor unions.

This study is an attempt to begin to correct these deficiencies by describing how the CGT, a once-powerful labor union under populism, lost strength under "neoliberal" democracy, and by applying the information gathered from this case study to the general process of democratization as it applies to labor unions in similar cases.

IV. FRAMEWORK

To better understand the nature of labor union decline, Sonia Dávila's framework of analysis ${ }^{17}$ is used in this thesis. Dávila studies the Central obrera Boliviana (COB), which traditionally has been Bolivia's strongest labor union confederation, looking at internal and external factors affecting labor unions. According to Dávila, external factors

${ }^{16}$ Zapata reviews the literature on labor issues and complains about the lack of studies on labor and labor unions in the process of democratization. Anthony o'Regan not only complains about the lack of literature on labor and institutions, but accuses the school of redemocratization (o'Donnel1, Smitter) for neglecting the role of civil society in general. Anthony o'Reagan, "What has been done? The Politics of Organized Labor in Argentina, 1976-1991," (Paper Presented at the XVII International LASA Congress, Los Angeles, California, September 24-7, 1992). Francisco Zapata, "Towards a Latin America Sociology of Labour," Latin American Studies 22 (1991):375-402.

${ }^{17}$ Sonia Dávila Poblete, "Apuntes para repensar el rol politico de la Central Obrera Boliviana," (Paper presented at LASA, September, 1992). 
are "those factors that come from actors' external actions and decisions, situated outside the realm of the labor movement that have an impact on the unions." 18 External factors are: the government and its capacity to implement economic and political reforms; the economic situation of the country; the international actors, such as the IMF, the United states, and other countries; and other internal actors, such as the Catholic church, the military, and political parties. ${ }^{19}$

Internal factors are "those factors that come from the internal actions and decisions of the labor movement, that affect the union collective action, its unity and behavior as an entity." 20 Internal factors are: the organic structure of the confederation; the country's political culture, that affects the way the union leaders react; the way the union relates to the workers and the union leaders, and the labor union's historical role. ${ }^{21}$

In the specific case of the CGT, this thesis will examine the following external factors: the implementation of economic reforms, "the selective dismantling of welfare legislation," 22 and several of the laws passed to control

\footnotetext{
${ }^{18}$ Ibid. , 6.

${ }^{19}$ Ibid.

${ }^{20}$ Ibid. , 7 .

${ }^{21}$ Ibid.
}

${ }^{22}$ Atilio Borón, "Becoming Democrats? Some skeptical Considerations on the Rights in Latin America," (Paper presented at the IPSA XV Conference, Buenos Aires, 1991), 7 . 
labor and other means of control that were used; the economic situation, and the international role of the IMF, the United states, and the globalization of the economy. Other actors will be briefly mentioned.

This thesis will also focus on the following internal factors: the history of the CGT, the organic structure of the CGT, the political culture of the leaders, and the relationship between the leaders and the rank and file workers as well as their relation with the population in general.

Dávila argues that the external factors are determinants of the COB's decline because they affected the internal composition of the unions. This thesis will further argue that within the external factors, the successful (in the IMF's terms) implementation of the neoliberal reforms in Argentina are the main factors that exacerbated the CGT's decline. Moreover, even though other factors contributed to the decline, neoliberalism was the major factor. It will be argued that the division of the CGT, diminished union membership, and the inability to strike are consequences of the implementation of the neoliberal reforms. Because of their importance, historical characteristics of the CGT will be analyzed as well.

V. ANALYTICAL TECHNIQUES

The unit of analysis is the Argentine CGT. "The rise and 
decline"23 of the Argentine labor union movement is significant because the CGT went from being a strong labor confederation under Peronism, to the weak organization that exists today under a Peronist president. By studying the Argentine case this thesis will attempt to see if generalizations can be made to other declining Latin American labor unions.

The rationale for studying a labor union confederation (as opposed to individual unions) is due to the availability of data and the simplicity of analysis and general conclusions. The same analysis can be applied to the labor union class (consisting of the workers from the formal and informal sector) or the different unions belonging to the CGT. The main argument of this thesis is that the decline of labor unions resulted from the implementation of neoliberal reforms. To successfully $y^{24}$ implement reforms, elites must break the structure of the labor movement. ${ }^{25}$ The decline of the unions will be defined as the loss of their political and economical power. The following political and economic

${ }^{23}$ Eduardo Gamarra, Market oriented Reforms and Democratization in Bolivia (Oversees Development Council: forthcoming).

${ }^{24}$ The term successfully does not refer to the distributive effect of the neoliberal reforms but to the ability to achieve what is considered successful in the eyes of the IMF and the international community in order to stabilize economies.

${ }^{25}$ This does not imply that labor unions are the only actors that need to be neutralized (see the Venezuelan case and the military crisis in 1992 or the Fujimori autogolpe in Peru), but since labor pays the highest cost of neoliberalism, it must be neutralized. 
sources of power will be considered: ${ }^{26}$

1. Density of union affiliation in the labor force

2. Density of union affiliation in the key areas of economic activities (wherever data is available)

3. Degree by which unions can indeed organize collective pressures to alter the labor markets

4. Internal unity

5. The use of the strike as the main labor union tool

6. Control of the social security funds

Data will be analyzed by linking the findings to the general framework, to determine whether a causal relationship exists between neoliberal reforms and labor union decline. This thesis will use a theory building structure, in which each chapter unravels a new part of the theoretical argument being made. It is the hope of this researcher that the analytical skills provided in the thesis, and the multiplicity of sources employed, will produce an awareness in the scholarly community of the urgency necessity to theorize about social actors under the present context of democracy.

The five chapters of research are structured as follows: CHAPTER ONE: Literature review: The Literature on

${ }^{26}$ Determinants one through three are suggested by valenzuela's framework to analyze labor in the transition period, four by Acuña, five by McGuire's analysis on strikes, and the control of social security funds by Smith. Samuel Valenzuela, "Labor Movement in Transitions to Democracy: A Framework for Analysis," Comparative Politics (July 1989); Carlos Acuña, "Política y economía en la Argentina de los 90," (Paper presented at the Conference on "Democracy, Markets and structural Reforms in Latin America," Buenos Aires, 1992); James McGuire, "Union Political Tactics and Democratic consolidation in Alfonsin's Argentina, 1983-89," IARR 27, (1992):37-74; Smith, "Neoliberal Restructuring." 
Democracies under Neoliberalism. Mechanism of Control-Labor and the state. Labor Literature. Labor Unions Decline and strength.

CHAPTER TWO: The external actors. The International Dimension. Neoliberalism and structural Adjustment. The United states and the Role of the IMF/World Bank. The Washington Consensus. Social Costs. The Relationship Between Economic Reforms and Labor. Argentina's Economy. Stabilization and Heterodox Measures: The Alfonsin Administration. Stabilization and orthodox Measures: The Menem administration. The Cavallo Plan. Flexibilization of Labor Markets.

CHAPTER THREE: The state and Labor Relations. The Political Consequences of Neoliberalism. Menem and His Ability to Govern. State Alliances. Labor Control. The Dismantiing of the Welfare Legislation. Problems of Governability. The Logic of Economic Versus the Logic of Politics.

CHAPTER FOUR: The History of the CGT. The CGT and its Ties With Peronism. The Internal composition of the CGT. The Division of the CGT. Its Appeal to the working class. The Loss of Economical and Political Power: Strikes and Social Security Funds. The CGT and the Business Class-Collective Bargaining Power.

CHAPTER FIVE: Conclusions. The Future of the CGT in the Context of Latin America. 
CHAPTER ONE. LITERATURE REVIEW

\section{INTRODUCTION}

During the 1980s, Latin American countries, with the exception of Haiti, Paraguay, and Chile, ${ }^{1}$ restored ${ }^{2}$ democracy $^{-}$ after a decade of one of the most brutal military dictatorships in the history of the region. ${ }^{3}$ The 1980 s wave of democratization captivated Latin American scholars, who concentrated on studying democracy in the area. Typologies of transition, differences depending on the previous military experiences, and comparative case studies were central to the

'Excluding are those countries with democratic governments for years, such as costa Rica, colombia, and Venezuela. Haiti became a democratic country in 1990 (although now it is a dictatorship), Chile in the 1990s, and Paraguay recently had elections (1993). Mitchell A. Seligson, "Democratization in Latin America: "The current Cycle," in Authoritarians and Democrats. Regime Transition in Latin America, eds. James M. Malloy and Mitchell A. Seligson (Pittsburgh: University of Pittsburgh Press, 1987), 3-12.

${ }^{2}$ Latin American history seems to go through "pendular cycles" from democracy to military dictatorship. According to Malloy: "The prevailing view among scholars is that democracy and authoritarian rule have oscillated throughout an extended series of cycles of roughly twenty years' duration and that this patten of oscillation, sometimes called a 'pendular pattern,' is likely to continue." Ibid., 4.

${ }^{3}$ The 1970 s military regimes used brutal repressive tactics, especially in the southern cone. In Argentina alone 125,000 people disappeared. For a good recount of the military in the southern Cone see: Alfred Stephan, Rethinking Military Politics: Brazil and the southern cone (Princeton: Princeton University Press, 1988). Also, see: Guillermo o'Donnell, Modernization and Bureaucratic Authoritarianism: Studies in South America (Berkeley: University of california Press, 1973). 
literature on democracy and transitions. ${ }^{4}$

since then, democratization literature has grown vastly. The present debate centers around: types of emerging democracies, prospects for stability and consolidation, and analysis of scenarios under political economic reforms. 5 Issues of political economy are common to the Latin American debate because of the gravity of the crisis. Latin American governments are trying to maintain a balance between their international financial obligations ${ }^{6}$ and pressures from national social actors.

With the return of democracy, society demanded all of the "good things" democracy was supposed to bring; however, the

${ }^{4}$ For more on transitions see Guillermo O'Donnell, Philippe C. Schmitter, and Laurence Whitehead, eds., Transitions From Authoritarian Rule: Latin America, (Baltimore: The John Hopkins University Press, 1986). Larry Diamond, Juan J. Linz, and Seymour Martin Lipset, eds., Democracy in Developing Countries. Latin America, (Boulder, Co: Lynne Rienner Publishers, 1989); and Seligson, Democratization in Latin America.

${ }^{5}$ The debate on what type of democracy is emerging and whether or not it is consolidated continues. In Guillermo o'Donnell terms "we still do not know what this 'animal' is...this social reality, in its relationship with political democracy, is not yet theorized and we need to develop theories, we need a definition...especially if some scholars want to speak of consolidated democracy." Giselle De Bruno, Rapporteur to the International Conference "Democracy, Markets, and Structural Reforms in Latin America," organized by the North-South Center, University of Miami and the Fundación Simón Rodríguez, Buenos Aires, March 25-27, 1992.

${ }^{6}$ The external debt now surpasses $\$ 430$ billion! Latin America (including the Caribbean) owes $\$ 430$ billion equivalent to $\$ 1,000$ per person, whereas per capita GNP is $\$ 2,000$ per year. For more on Latin American external debt see: Eliana Cardoso and Ann Helwege, Latin America's Economy: Diversity. Trends, and Conflicts (Cambridge, Mass: The MIT Press, 1992). 
problems of the region proved more than just "democracy" was needed to solve the political and economical crisis. ${ }^{7}$ The key issue, in william Smith's terms, became how to reconcile two perverse logics: (1) the "logic of citizenship, implying a commitment to political equality and the progressive removal of barriers to political participation," and (2) the logic of economic distribution, in "a system of production and a class structure that generates profound inequalities of wealth, income, and life chances." 8 Scholars subsequently began to focus on how democratic governments of the region could conciliate those demands.

From distribution and accumulation issues emerged an interesting debate on democratic consolidation. Some authors argue that democracy in the region is consolidated because

${ }^{7}$ In Liberal America, Packenham addresses "four main liberal assumptions" that were thought to work in Latin America development politics: "change and development are easy," "all good things go together," "radicalism and revolution are bad," and, "distributing power is more important than accumulating power." The assumption that democracy brings economic welfare and the solution to every problem in society tricked many Latin American leaders, making them believe that "democracy alone" would solve the economic crisis. Raull Alfonsin, in one of his first speeches, said: "With democracy alone we eat, educate, and cure." Five years later he left office before his term ended because of the magnitude of the economic crisis. For more on the american liberal tradition see: Robert A. Packenham, Liberal America and the Third World; Political Development Ideas in Foreign Aid and Social Science (Princeton: Princeton University Press, 1973).

${ }^{8}$ William Smith, Authoritarianism and the crisis of the Argentine Political Economy, (Stanford: Stanford University Press, 1989), 268.

9See: Acuña, "Politica y economía en la Argentina de los 90 ," for more on consolidated democracy. 
the possibility of a military coup seems remote, regardless of the gravity of the economic crisis. Others are more cautions, and call this period a period of "democratization" or "continuity stage," in which "consolidation" means more than the absence of an imminent military threat or the presence of formal elements of democracy (such as free elections). ${ }^{10}$ For Gamarra, Malloy, Conaghan, and others, the ability to govern becomes a complex process while managing the economy and the social actors affected by the decisions taken by the leaders. The process of democratization involves issues of governability in a context of economic constraint and lack of resources.

In an attempt to explain the unfolding reality of democratization (the global process)," political scientists

${ }^{10}$ Samuel Valenzuela, Eduardo Gamarra, James Malloy, and Guillermo O'Donnell among others. The term "continuity stage" appears in Eduardo Gamarra's, Market oriented Reforms. This was from a draft of Dr. Gamarra's book quoted with his permission; in the forthcoming book, page numbers and exact quotations may appear different.

${ }^{11}$ James Malloy in "The Politics of Transition in Latin America" in Authoritarian and Democrats, eds., James Malloy and Mitcheli A. Seligson (Pittsburgh: University of Pittsburgh Press, 1987),p.4, suggests that the lack of literature on vital aspects of Latin American issues is due to the fast pace of the Latin American reality and says:

Theoretical developments have been strongly influenced by short-term events and theories are soon discarded when confronted with a more enduring reality. In the fifties and early sixties, the main concern in the study of Latin American politics was the evaluation of the socioeconomic requisites for democracy...t the new militarism... [in] the mid-sixties and the seventies,... in the eighties... the prospects and processes of redemocratization, [and, I may add, in the nineties the main concern is on neoliberalism reforms under democracies]. 
have neglected the role of the specific social actors and institutions dramatically affected by these changes. Explaining the global phenomenon is important; however, studying specific social actors and institutions allows for a better understanding of the interaction between the global phenomenon and the specific realities in each country and each actor. ${ }^{2}$ Although most studies recognize that civil society is declining in the context of economic stabilization, ${ }^{13}$ few studies explain how civil society is declining; what specific processes explain the decline; and, why they are declining.

This thesis is an attempt (by no means exhaustive) to bridge the literature gap on one of the key actors in the process of democratization: labor unions. ${ }^{14}$ This thesis will attempt to explain the decline of Argentine labor in the

\footnotetext{
${ }^{12}$ Recently, an interest is re-appearing in studying civilmilitary relations under democracy. While this is a good step towards studying an important social actor like the military, the interest in studying other important social actors still has to develop. O'Regan goes complains not only about the lack of literature but blames the school of redemocratization (O'Donnell, Smitter) for neglecting the role of civil society in general. See o'Regan, "What has Been Done?"

${ }^{13}$ See section II.

${ }^{14}$ In "The Politics of Transition," p. 254 Malloy argues that:

Since the 1930s, no group has been more crucial to the success of any regime than organized labor...hence, since the 1960 s all regimes, authoritarian and democratic alike, have found themselves in confrontation with labor over who should bear the burden of development. Most regimes have moved to shift those costs by curtailing or eliminating the political power and participation of labor.
} 
context of neoliberalism, while arguing that neoliberalism is the cause for the decline.

II. THE LITERATURE ON DEMOCRACIES UNDER NEOLIBERALISM At the end of the 1980 , $^{15}$ Latin American leaders who come to power under populist platforms abandoned Keynesian ${ }^{16}$ economics and implemented free market economic reforms, a la' Adam Smith. 17 The implementation of economic reforms by democratic governments defied traditional arguments that linked austerity reforms with authoritarianism. ${ }^{18}$ The so called "second generation of leaders"19 implemented the

${ }^{15}$ Note that not all Latin American countries implemented economic reforms at the same time. Chile and Bolivia were the first countries to start the reforms followed by Argentina, Peru, Brazil and others.

${ }^{16}$ Keynesian economics refers to the widespread influence of macroeconomics forecasting and fiscal planning to stimulate development. This was known after the famed British economist John Maynard Keynes, who pushed the idea in the 1930s. As Gillis et al. explain: "The fiscal policy was simple: when faced with inflation enact tax increases and cut government expenditures to reduce aggregate demand; in recession implement the same set of measures in reverse." Malcolm Gillis, Dwight H. Perkins, Michael Roemer, and Donald R. Snodgrass, Economics of Development second edition (New York: W.W. Norton \& Company, 1987), 315.

${ }^{17}$ Among other measures, the economic reforms involve privatization, faith in the market as the allocator of wealth distribution, open markets, modernization of the state, deregulation, and competitive re-insertion in the world economy. For more see: Cardoso, Latin America's Economy. Also, see chapter two following in this thesis.

${ }^{18}$ Karen L. Remmer, "The Politics of Economic stabilization. IMF standby Programs in Latin America, 19541984," Comparative Politics (October 1986): 2-24.

${ }^{19}$ The second generation of leaders refers to the presidents who came to power after the leaders from the transition, around the 1990s, and are implementing neoliberal economic reforms, such as Carlos Menem, Alberto Fujimori, and 
reforms through peculiar political arrangements. ${ }^{20}$

For example, Carlos Acuña argues that the present democracy is a "neoliberal democracy," also called "fragmentary democracy." According to Acuña, its consolidation, governability, and stability is based on the "disarticulation of the popular sector's capacity to contest" and "the exclusion of key political and economic social actors."22 This political arrangement is characterized by:

lower levels of distribution of capital goods (meaning the combination of wages, employment, and resources associated with social protection perceived by the popular and worker sections); less distribution of political and institutional resources (meaning the extension of social rights, rules and organizational goods that increment the collective action of subordinates social groups); a weakened civil society; high concentration of wealth, and a centralization of the decision making power... A fragmentary democracy is a highly exclusionary type of democracy, which governability is based on the economic and political exclusion of important social groups. ${ }^{23}$

consequently, political arrangements under "neoliberal

Collor de Melo.

${ }^{20}$ Ibid., 239. Politics are conditioned by economics, not in a determinist sense but in an interrelated sense, where politics are not autonomous from the economic environment and are shaped by economics. Political decisions taken or avoided have important social and economic consequences. John Peeler, Latin American Democracies. Colombia, Costa Rica, Venezuela (Chapel Hill: The University of North Carolina Press, 1985.)

${ }^{21}$ Acuña, "Politica y economía en Argentina de los 90." Also discussed in Dávila's essay on the COB. Sonia Dávila Poblete, "Apuntes para repensar." See discussion on section $v$. 30.

${ }^{22}$ Acuña, "Política y economía en la Argentina de los 90," ${ }^{23}$ Ibid. 
democracy" or "fragmentary democracy" 24 are based on not so democratic arrangements that exclude an important segment of society: labor and labor unions.

James Malloy also speaks in terms of "exclusionary" and "inclusionary" regimes. 25 According to Malloy, Latin American governments go through cycles, from "populist or inclusionary" regimes to "anti-populist or exclusionary" ones. He argues that under "populist or inclusionary regimes," the state provides channels to co-opt labor, whereas under "antipopulist regimes" the state aims specifically at "dismantling" the co-optive structure of 1 abor and populism. ${ }^{26}$

Malloy contrasts the economic crisis of the Great Depression, which was solved by government compromising with labor, with the present crisis, which is being solved by placing capital as "the winner of the game" and "labor" as the "greatest 1oser." 27 In the wake of democratization,

${ }^{24}$ Acuña's description of a fragmented democracy is clear and accurate, however, his concept that these democracies are consolidated type of democracies is debatable. William Smith, Carlos Acuña, and Eduardo Gamarra, eds., Democracy, Markers and structural Adjustment in Latin America (New Brunswick: Transactions, forthcoming).

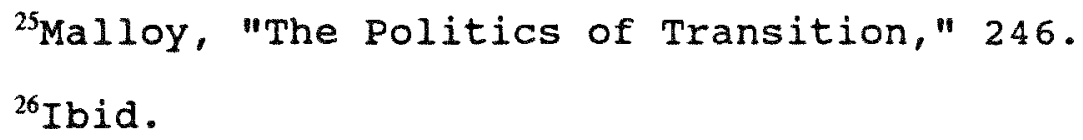

${ }^{25}$ Malloy, "The Politics of Transition," 246.

${ }^{26}$ Ibid.

${ }^{27}$ Ibid. Also see: Atilio Borón, "Becoming Democrats? Some skeptical Considerations on the Right in Latin America." Also O'Donnell and the argument of the exhaustion of the import substitution strategy and the look at different alternatives. With import substitution and the growing of the size of the working class, the state encouraged participation through labor unions to control them. For reason that explains the exhaustion of one model and the replacement for other see: Guillermo o'Donnell, Bureaucratic Authoritarianism: 
governments are decentralizing traditional political structures, siding with the conservative right, and excluding labor from the decision making power. The reforms of carlos Menem in Argentina or Alberto Fujimori in Peru imply not only alignment with the conservative right, but a re-accommodation of actors.

The political arrangements described by Malloy and Acuña are expanded in Marcelo Cavarozzi's essay "Beyond Transition to Democracy in Latin America."28 Cavarozzi focuses on the "new societal structure" created under neoliberalism, by contrasting this matrix with what he calls "the state centered matrix (SCM), "29 which disappeared in the 1980s. The SCM had the following characteristics:

Argentina, 1966-1973, in Comparative Perspective (Berkeley: University of California Press, 1988); idem, "state Alliances in Argentina, 1956-1976," Journal of Development studies (1978) $15: 3-33$.

${ }^{28}$ Among others see Borón, "Becoming Democrats?; Marcelo Cavarozzi, "Beyond Transitions to Democracy in Latin America," (Paper presented at the IPSA XV Congress, Buenos Aires, 1991); Rosario Espinal, "The Right and the New Right in Latin America," (Paper presented for the Research conference "The Right in Latin American Democracies," Columbia University, New York, April 20-21, 1990); Torres, "América Latina."; Catherine Conaghan, James M. Malloy, and Luis Abugattas, "Business and the Boys: The Politics of Neoliberalism in the Central Andes," LARR 25:3-30; Douglas A. Chalmers, Maria do Carmo Campello de Souza and Atilio Borön, eds., The Right and Democracy in Latin America (New York: Praeger, 1992).

${ }^{29}$ Several other authors have done research on the state centered matrix. See Cavarozzi, "Beyond Transitions" for a detailed analysis and a good bibliography; idem, "The Left in Latin America. The Decline of Socialism and the Rise of Political Democracy," (Paper presented at the IPSA XV Conference, Buenos Aires 1991). Cavarozzi studies the cases of Brazil, Mexico, Argentina, Chile, and Uruguay during the 1930 s. 
1. a state controlled market for goods and labor

2. diversified market economies

3. production in the domestic market with high rates of growth

4. expansion of economies ultimately controlled by large private firms

5. strategic decisions on economic policies separate from politics

6. expanded civil society, with an emergence and strengthening of organized labor

7. creation of corporatist and quasi-corporatist channels linked to public organizations, political parties, professional associations, and unions (with clientelistic patterns around the state). ${ }^{30}$

At the core of the SCM was labor and the labor movement. When the SCM collapsed as a result of the triumphant right, workers, peasants, and the poor also disintegrated "largely because they had been centered around the state." 31 cavarozzi suggests that building a new neoliberal matrix requires:

"dismantling the corporatist structure and clientelistic control over popular sectors; (2) reversing the insulation of the economic policy-making mechanisms from representative institutions and practices; and, (3) eradicating all forms of military tutelage over politics." ${ }^{32}$ Latin American governments are controlling popular sectors by neutralizing labor and opening their economies to the world. Popular literature

${ }^{30}$ Ibid., 14-23. Cavarozzi's enumeration is summarized; however, number four and seven are textual quotes, while the others contain terms from Cavarozzi.

\footnotetext{
${ }^{31}$ Ibid.

${ }^{32}$ Ibid., 33
} 
concurs that neoliberal reforms imply a movement of labor to the periphery and capital to the core. Before analyzing the ways this displacement occurred, it is important to clarify the term "neoliberalism."

III. NEOLIBERALISM

The term "neoliberalism" began appearing in the political economic discourse of the 1980s, as a result of a global triumph of Thatcherism and its American version: Reaganism. ${ }^{33}$ Margaret Thatcher denounced the deficiencies of socialism and the British Labour Party, the inefficiencies of the state, the abusive practices of labor unions, and the corruption of the social security system. Blaming the world wide recession to leftist political ideals, Thatcher exalted the benefits of individualism to an extreme. New Latin American democracies adopted this ideology, also to an extreme, ${ }^{34}$ blaming the deterioration of their economies on populist models and the state, without considering the particular situation of Latin American dependent economies.

According to Conaghan, neoliberalism ${ }^{35}$ refers to the

${ }^{33}$ Tito Livio Caldas, "Thatcher: precursora neoliberal," El nuevo Herald, 12 March 1993, sec. 9A.

${ }^{34} \mathrm{Smith}$ explains that contemporary followers of the post 1920 s purists go beyond the defense of balanced budget and attacks on state intervention to critic the "pernicious effects of state collusion with monopoly and oligopoly, private sectors interests, and organized labor." Smith, "Neoliberal Restructuring," 3 .

${ }^{35} \mathrm{~A}$ majority of Latin American scholars and Spanish speaking authors prefer the term neoliberalism to the English term neoconservative. Foxley and other authors use the term neoconservative; also, Jose prefers this term. The confusion 
"economic policies that combine stabilization measures with a long-term commitment to restructuring the economy by reducing the role of the state and subjecting economic activity to free market forces."36 José Ramos argues that neoliberal economic reforms include a common strategy used in the southern cone:

1. Freeing prices to reflect costs

2. Eliminating import licenses and reducing tariffs while choosing an exchange rate that encourages trade

3. Freeing interest rates and eliminating controls over the allocation of credit

4. Promoting free entry and exit of capital

5. Preventing all forms of collusion, including labor unions [emphasis added] and professional groups

6. Reducing the participation of the public sector in production

7.Eliminating fiscal deficits and strictly controlling monetary growth ${ }^{37}$

According to Ramos, neoliberal economic reforms are similar to orthodox reforms, except that they tend to

comes from the differences in what is meant by 1 iberal and conservative in the US and in Latin American. The Latin American liberal economist follow the free market thoughts of Adam Smith and Frederick August Hayek, but are usually politically conservatives. U.S. Iiberal are socially oriented, favoring protectionism and state intervention. This thesis uses the term neoliberalism implying a resurgence of the 1930s liberal thought as a culmination of a process that started with the Austrian School and the economist thought of Ludwig Von Mises and Hayek. Alejandro Foxley, Latin American Experiments in Neoconservative Economics (Berkeley: University of California Press, 1983):15-7; quoted in Conaghan et a1., 28 .

\section{${ }^{36}$ Conaghan et al., 28.}

${ }^{37}$ José Ramos, Neoconservative Economics in the Southern cone of Latin America (Baltimore: Johns Hopkins University, 1986); quoted in Cardoso, Latin America's Economy, 180. 
emphasize "a fixed exchange rate as a vehicle de-inflation." 38 From a political perspective though, when Latin American governments implement neoliberal economic reforms, both the economy and society are being reformed. The reforms imply a commitment from a wide array of groups ${ }^{39}$ who support the neoliberal reforms to the detriment of the popular sectors. These reforms generate the type of political arrangements or matrix described by Cavarozzi. ${ }^{40}$ Most scholars agree that politics and economics are intertwined, especially with these economic reforms. ${ }^{41}$

Rosario Espinal further distinguishes between neoliberalism as a "political project" and neoliberalism as "policy making." According to Espinal, "neoliberalism as a political project is a system of ideas with a comprehensive political discourse that seeks to modify state-society relations by placing the 'market' [emphasis added] as the

${ }^{38}$ Ibid.

${ }^{39}$ As Atilio Borón argues: "a glance at the Latin American political panorama is enough to conclude that former populist movement and center left parties or coalitions have increasingly adopted neoconservative public policies leading to the reinforcement of capitalist hegemony in the region." Borón, "Becoming Democrats?" 30. In Argentina, Peronists have sided with the liberal party of Alvaro Alsogaray, who was associated with the former conservative military dictatorship.

${ }^{40} \mathrm{Al}$ so Acuña (1992), and Malloy (1989).

${ }^{41}$ Although some authors, like Garretón, do not see a connection between politics and economics, a majority do. Manuel Antonio Garretón, "La dimension politica de los procesos de transformación en Chile," (Paper presented at the Conference on "Democracy, Markets, and structural Adjustments," Buenos Aires, 1992). 
supreme terrain of social relations." Neoliberalism as a political project is related to the ideas previously discussed.

Neoliberalism as "policy-making" is "policy imposition [from top down] to cure economic ills, with little regard for popular needs."43 These policies are implemented through decrees, with little or no consultation with the congress or the popular sectors, regardless of the harsh consequences for the vast majority of the working class, such as: wage freezes, budgets cuts, lower tariffs, devaluation, wage competitiveness, increased unemployment, and a decline in living standards. As a result, "the drop in living standards undermines the ability of labor unions to effectively represent workers, as reflected in organized labor's diminished legitimacy, internal divisions, and chastened military." 4

Conversely, neoliberal economists argue for a flexible, deregulated labor market, praising the "goodness" of weak labor unions. They argue that workers will be free to choose where to work without having to belong to a union as a

${ }^{42} \mathrm{placing}$ the market at the center of the "new matrix" in Cavarozzi's terms, implies excluding labor from the core of the matrix. Rosario Espinal, "The Right and the New Right," 9 .

${ }^{43}$ Ibid.

${ }^{44} J$ ohn Walton, "Austerity and Labor," Hemisphere (Winter/Spring 1990): 10 . 
condition to find a job. ${ }^{45}$ Moreover, neoliberal economists and authors such as Hernando De Soto's in The other Path, ${ }^{46}$ argue that the growth of the informal sector will provide the necessary cushion for the reforms to work, in a simplistic assumption that markets alone will balance the supply and demand of prices and labor. However, the debate on the informal sector and the benefits of neoliberal reforms for the poor is still incomplete. ${ }^{47}$

Efrén Córdova, a specialist on Latin American labor, acknowledges that the term informa ${ }^{48}$ is vague. Córdova argues that "the informal" includes an heterogenous mass of "self employed workers; sporadically and seasonally workers; workers in small, including family, enterprises; undocumented workers, workers in unregistered businesses, underemployed

${ }^{45}$ Cardoso, Latin America's Economy, 1992. Although the conditionality of belonging to a union may have some truth, at least workers were able to find a job; whereas now they have no protection whatsoever because there are no jobs.

${ }^{46}$ Hernando De Soto, The other Path: The Invisible Revolution in the Third World (London: I.B. Tauris, 1989).

${ }^{47}$ Traditionally, economic literature on neoliberalism did not mention the negative effect of neoliberal policies on the poor. Only recentiy economists who advocate economic reforms started to write on how adjustment programs affect the poor and ways to decrease the effects. However, there is no agreement on how to solve the problem. For an IMF perspective see: Yukon Huang and Peter Nicholas, "The Social Costs of Adjustment. How Adjustment Programs Affect the Poor, and How the World Bank is Helping Ameliorate their Effects," Finance and Development (a quarterly publication of the IMF and the World Bank) 24, no. 2 (June 1987). For a leftist perspective see: "Report on the Americas. A Market Solution for the Americas?" Published by NACLA XXVI, 4 (February 1993).

${ }^{48}$ Efrén Córdova, "The Informal Challenge," Hemisphere, (Winter/Spring 1992): 32 . 
workers; and housemaids, artisans, and laid-off factory workers performing odd jobs."49 Alejandro Portes, who has studied the informal sector in depth, also considers "casual wage labor, disguised wage labor, and self-employment in petty production and trade," ${ }^{50}$ part of the informal.

Previous studies on the informal sector argued that the informal was a characteristic of traditional societies. ${ }^{5}$ Yet, the reality of Latin American economies proved that the informal is part of the capitalist economies as well. According to Portes, "there is no reason to expect that the informal sector will disappear through gradual 'involution' and every reason to anticipate that it will continue to exist and expand."52 Although there is no agreement on what the informal is, the growth of this sector is "no longer a marginal phenomenon." ${ }^{53}$ Portes suggests that urban informal constitutes 40 percent and 56 percent of the non-agricultural labor force in Peru and Bolivia respectively. ${ }^{54}$

Córdova concludes that belonging to the informal sector is not by choice but is due to the failure of the neoliberal

${ }^{49}$ Ibid.

${ }^{50} \mathrm{Alejandro}$ Portes and John Walton, Labor Class and the International System (New York: Academic Press, 1981): 103 .

${ }^{51}$ see Córdova, "The Informal challenge."

${ }^{52}$ Ibid. , 105.

${ }^{53}$ Ibid.

${ }^{54} \mathrm{Alejandro}$ Portes, quoted in Conaghan et al, 25. See also: John Walton, "Austerity and Labor." 
economies to generate sufficient employment. He further argues: "In the language of the International Labor Organization, today's informal workers are largely 'excess' members of the labor force who must generate their own means of earning a living."55 The informal workers lack the training and education to enter today's highly competitive market. Consequently, they remain in poverty, ${ }^{56}$ unless the economies generate more jobs. In short, the growth of the informal sector should be included in an analysis of labor and labor union decline.

IV. MECHANISMS OF CONTROL-LABOR AND THE STATE

In contrast to the United states and other advanced nations, in Latin America the state played a decisive role in shaping labor union structure, the collective bargaining process, and setting the labor working conditions themselves. ${ }^{57}$ Furthermore, the state in Latin America: has traditionally been an important employer; ${ }^{58}$ (2) has

\footnotetext{
${ }^{5 s}$ Córdova," The Informal Challenge."

${ }^{56}$ Ibid, 32.
}

${ }^{57}$ Although McGuire describes the Argentine state, his conclusions can be generalized to other Latin American states. James McGuire, "Union Political Tactics," 2. Also see: Henry A. Landsbserger, "The Labor Elite: Is it Revolutionary? " in Elites in Latin America, eds. Seymour Martin Lipset and Aldo Solari (New York: Oxford University Press, 1967):256-30; and, The International Labor office "Labor Legislation and Collective Bargaining in the Americas," International Labor Review 84 (July-December, 1961):290.

${ }^{58} \mathrm{Hector}$ Palomino calculated that in 1987 , the Argentine state employed a quarter of Argentina's economically active population. Hector Palomino, Cambios ocupacionales y sociales en Argentina 1971-1985 (Buenos Aires: Centro de 
manipulated important economic variables such as the exchange rate, interest rates, aggregate wage and employment levels; ${ }^{59}$ (3) has been the authority charged with recognizing unions, declaring strikes illegal, and regulating collective bargaining; (4) and, oversaw union finances and elections.

The Latin American state supported labor, especially under populism; but under neoliberalism a profound transformation is happening. The traditionally protective state is attempting to decentralize labor through several mechanisms of control. ${ }^{60}$ Several scholars expanded on the various mechanisms used by governments to control labor and the masses.

McCamant, for example, lists three methods of control. ${ }^{61}$ The first is a coercive method employed by the military: repression. The military incarcerated hundreds of labor unionists or simply made them "disappear." Labor under the

Investigaciones sociales sobre el estado y la administración, 1987). In Costa Rica, 91 percent of unionized workers are state employees, see steve Levitsky and Tony Lapp, "Solidarismo and Organized Labor," Hemisphere (Winter/Spring 1992):26-30.

${ }^{59}$ Henry Landsbserger correctly adds minimum wages, overtime, length of vacations, holidays, severance pay, health and pension plans as also regulated by the state. Landsbserger, "The Labor Elite," 290.

${ }^{60} \mathrm{~A}$ detailed analysis on the Argentine situation will be developed in chapter three.

${ }^{61} \mathrm{John}$ McCamant, "Democracy and Domination: Latin America and Eastern Europe," Global Justice v.2, n.3 (Sep/Oct 1991):18. Although his argument is interesting, it omits co-optation, which is an important method of control. co-optation is discussed a few paragraphs later. 
military was muted and destroyed. ${ }^{2}$ The other two methods are non-coercive methods used by democratic governments: unemployment and public relations. ${ }^{63}$ According to McCamant, unemployment is a key feature of neoliberal economic reforms. Classical economic theorists argue for the necessity to have a certain number of unemployed people to balance the economy. ${ }^{64}$ with privatization, jobs become scarcer, as the labor market becomes tighter and more competitive. Under these circumstances, "hiring and firing become powerful instruments of control. With many applicants for every position, workers are not about to risk their livelihood through labor militancy."65 The hiring and firing mechanism undermines the ability of labor unions to strike.

Public relations, as a mean of control, refers to the ability to use mass communication, such as radio or television, to promote right-wing campaigns. The charisma of leaders plays a fundamental role in seducing the undereducated masses. ${ }^{66}$ Francisco Zapata also discusses coercive and noncoercive means to control labor. ${ }^{67}$ Among other indicators,

\footnotetext{
${ }^{62}$ For more on the literature on labor under the military see Linda Chen, "Labor Unions and Regime Transition in Argentina," (Ph.D. Dissertation, University of Mass., 1988).

${ }^{63}$ Mccamant, "Democracy and Domination."

${ }^{64}$ See Gillis et al., Economics of Development, 175-205.

${ }^{65}$ MCCamant, "Democracy and Domination," 5 .

${ }^{66}$ Ibid.

${ }^{67}$ Francisco Zapata, "Towards a Latin American Sociology."
} 
Zapata mentions: non-recognition of unions, co-optation of leadership, de-legitimation of new leaders through accusations of theft, non secret balloting at union election, and convocation of union meetings with little previous notice. ${ }^{68}$ Governments resort to any means to undermine economic and political power of labor unions.

For example, Acuña cites Carlos Menem's ability to implement a successful strategy to neutralize the CGT. Menem attacked the social security system to diminish unions's economic power and is using massive layoffs, suspensions, and pacts, to undermine the political power of unions. In a sense, Menem undermined labor's power through the famous Machiavellian principle "divide and conquer. " ${ }^{69}$

The literature is rich on the concept of crafting alliances or pacts as ways to control labor and opposition in general. ${ }^{70}$ Eduardo Gamarra, for example, argues that

${ }^{68}$ Ibid.

${ }^{69}$ In 1989, the Menem divided the CGT into two sectors, the CGT San Martin (pro-Menem) and the CGT Azopardo (oppose to Menem). Menem proclaimed the CGT Azopardo illegal, and declared the CGT San Martin the only legal CGT. See Acuña, "Politica y economía en la Argentina de los 90,"9-10.

${ }^{70}$ See Malloy, "The Politics of Transition"; Conaghan et.al., "Business and the Boys"; and Espinal, "The Right and the New Right." Also Blanca Heredia, "Economic Change and Political Order: Governance and Democracy in Mexico," (Paper presented at the Conference on "Democracy, Markets, and Structural Reforms" organized by the North South Center, University of Miami and the Fundación Simón Rodriguez, Buenos Aires, 25-27 March 1992); Jaime Ross, "On the political Economy of Markets and State Reform in Mexico, "presented at the previous conferences; and, Eduardo Gamarra, "Crafting Political Support for Stabilization: Political Pacts and the New Economic Policy in Bolivia," also presented at the same 
convenient electoral coalitions, once in power, need to build "ruling or sustaining coalitions" to carry on the economic and political reforms." Moreover, Gamarra argues that because Latin American political parties and legislatures are weak, governments resort to all means, including patronage, ${ }^{72}$ as tools to control labor and other political actors. Strong Latin American executives craft politically viable ways of dealing with a difficult situation through exclusionary politics. ${ }^{73}$

In this game of the "ins" vs. "outs," in Gamarra and Malloy's terms, labor is definitely left out of the alliances. ${ }^{74}$ The ability of government to control labor and effectively manage the economy become key to the issue of

conference.

${ }^{71}$ Gamarra, Market oriented Reforms, 91.

${ }^{72}$ The literature is divided on this issue; while for some authors patronage is a reality in Latin American because of the scarce capital accumulated and the necessity to keep the system working (Gamarra, Malloy, Heredia), for others patronage means corruption and it needs to be eliminated from the system. Lipset argues that "corruption in the unions is an index of the relative absent of idealism and collective orientation, is an indicator of personal material aspiration and it is also and index of the values system of the society in which they are found." See S.M. Lipset, "Trade Unions and Social Structure II," Industrial Relations I 2 (February 1962):90, quoted in Landsberger, "The Labor Elite," 282. Eduardo Gamarra, "Crafting the Political Support."

${ }^{73}$ Gamarra, Market oriented Reforms, 97.

${ }^{74} \mathrm{O}$ 'Donnell speaks of exclusionary vs. inclusionary governments, Waissman distinguishes between inclusionary, exclusionary, and co-optive policy, Gamarra and Malloy refers to the ins and out. Waissman, Reversal of Development. Gamarra, Market oriented Reforms. Malloy, "The Politics of Transitions." 
"governability." "75

From the rich literature on state and labor control, it can be concluded that the state resorts to three means of control: economic means, coercive means, and pacts. The following illustrates the three groups:

ECONOMIC MEANS ${ }^{76}$

* Low wages

*unemployment

* growth of the informal sectors

*massive lay offs

COERCIVE MEANS ${ }^{n}$

PACTS *physical force, assassination, or imprisonment (used by the military)

*internal exile of leaders (case of Bolivia) 78

* state of sieges

* laws aimed to undermine labor economic power, such as control of social security funds or collective bargaining

* laws or decrees aimed to undermine labor political power, such as declaring strike illegal, unemployment compensation, accident injury compensation, social benefits, or declaring some sectors of the labor movement illegal (Menem)

* Machiavellian pacts $^{79}$ aimed to divide

${ }^{75}$ Gamarra, Market oriented Reforms.

${ }^{76}$ Contrary to this explanation, this thesis argues that the implementation of the economic reforms causes labor unions to decline, more than being a governmental tool to neutralize labor. Once the reforms are implemented, the state needs to control labor because of the harshness of these reforms and may resort to lay off threats to further stop any action against the intended reforms.

${ }^{77}$ From more to less coercive.

${ }^{78}$ Conaghan et al., "Business and the Boys."

${ }^{79}$ Gamarra speaks of the ability of the leader to transcend what he calls the "threshold of crisis," by exercising an incredible capacity to govern in an adverse situation of economic crisis and political paralysis. Malloy refers to the 
the labor unity

*co-optive pacts exchanging conformity for reforms for governmental positions

*pacts with business aimed at excluding labor

\section{LABOR LITERATURE ${ }^{80}$}

Labor studies have undergone a profound transformation since the 1960s. ${ }^{81}$ Traditionally, the study of the labor movement involved the idea that labor was by nature revolutionary. ${ }^{82}$ Therefore, a majority of the literature

moment as the "Machiavellian moment," a moment in which "leadership animates a set of formal institutions through the creative deployment of 'practices' which can be repeated and/or built upon as problems are resolved and new one confronted over time." See Gamarra, Market oriented Reforms, 99, 113. A detail analysis of President Menem's ability to overcome the "threshold of crisis" will be provided in chapter three.

${ }^{80}$ Two very helpful bibliographies, non-annotated are: John French, Latin American Labor Studies: A Bibliography of English Language Publications through 1989 (Miami: Florida International University, CLRS, 1989); idem, Latin American Labor studies: An Interim Bibliography of Non-English Publications (Miami: Florida International University, CLRS, 1989).

${ }^{81}$ Several review articles analyze the development of labor studies. Zapata, "Towards a Latin American Sociology"; Peter De Shazo, "Workers, Labor Unions, and Industrial Relations in Latin America," LARR 23 (1988):145-56; Anthony O'Regan, "What Has Been Done?"; Kenneth P. Erickson, Patrick V. Peppe, and Howard A. Spalding Jr., "Research on the Urban Working Class and Organized Labor in Argentina, Brazil, and Chile: What is Left to Be Done?" LARR IX (Summer 1974):115-42.

${ }^{82}$ Mainly the modernization school of thought. The main trend at the time is expressed in Robert Alexander words: "Labor itself is an integral part of the Latin America revolution ... [and] has a wider scope of activities and different attitudes than the labor movement in the United States." Robert Alexander, organized Labor in Latin America (New York: The Free Press of Glenco, 1965), 12. For an excellent study of the origins of Latin America labor unions from a leftist perspective see Howard Spalding, organized Labor. 
focused on labor union ideology. In recent years, however, labor scholars have focused on sociological aspects of labor, expanding the field of labor studies tremendously. Present research includes: the role of labor movements in politics (Bailey); the role of labor under Peronism (Waissman) and Post-Peronism in the case of Argentina (James); the role of labor in key economic sectors(Bergquist), democracy and relations of authority on the shop floor (Cavarozzi); and, state-labor relations and autonomy (Epstein). ${ }^{83}$

The rich literature on the history of labor unions allows for a contrast between the powerful status of labor unions under populism with its present decay. ${ }^{84}$ Yet the literature on labor unions under democratization is incipient. Several labor theorists criticized the absence of scholarly works regarding the role of labor under democratization ${ }^{85}$ and noted

${ }^{83}$ Samuel Bailey, Labor, Nationalism, and Politics in Argentina (New Brunswick: Rutgers University Press, 1967); Waissman, Reversal of Development; Marcelo Cavarozzi, Clase obrera y sindicatos en la Argentina (1955-1973) (Buenos Aires: CEDES, 1982); Daniel James, Resistance and Integration.; Charles Bergquist, Labor in Lat in America: Comparative Essays on Chile, Argentina, Venezuela, and Colombia (Stanford: Stanford University Press, 1986); Labor Autonomy and the state in Latin America, ed. Edward Epstein (Boston: Unwin Hyman, 1989).

${ }^{84}$ On labor in Argentina see: Bailey, Labor, Nationalism, and Politics; Bergquist, Labor in Latin America the chapter on Argentina; Spalding organized Labor; Waissman, Reversal of Development. On Peronism see Miguel Murmis and Juan Carlos Portantiero, Estudios sobre los origenes del peronismo Buenos Aires: Siglo Veintiuno Argentina Editores, 1971); Joseph Page, Perón: A Bibliography (New York: Random House, 1983).

${ }^{85}$ zapata's review essay and the review essays mentioned above all concur on this lack of focus on the role of unions and democratization. A key area that needs research is the 
the urgent need to theorize labor unions decline (O'Regan, Valenzuela, Zapata, De Shazo). Even though scholars have not yet developed theories to explain labor's decline, some scholars have studied partial aspects of labor. The following section will attempt to answer: What is meant by labor's decline?, What constitutes labor union strength?, How is the decline of labor measured?, Are there any reliable means to operationalize the decline?, What are the sources of labor unions power?

VI. LABOR UNIONS DECLINE AND STRENGTH

Samuel Valenzuela ${ }^{86}$ developed a framework to study labor movements under transitions, linking regime type to labor strength. Valenzuela argues that authoritarian governments follow two strategies toward labor organization: a "corporatist strategy," and a "market strategy." 87 Using the corporatist strategy, the state creates some form of worker organization, incorporating labor into the state. Using a market strategy, the state tries to "weaken unions as bargaining agents," decentralizing collective bargaining. ${ }^{88}$

analysis of the implementation of liberal economics policies on the structure of the system of labor relations, the socalled "institutional framework which has been changed and adapted to meet the new conditions of capital accumulation." Zapata "Towards a Latin American Sociology," 397.

${ }^{86}$ Samuel J. Valenzuela, "Labor Movements." Although this thesis will attempt to explain labor unions after the transition is over, some important conclusions can be extracted from Valenzuela's essay.

${ }^{87}$ Valenzuela, "Labor Movements," 448.

${ }^{88}$ Ibid. 
The decision to follow one or the other strategy is based on the type of regime in power.

Valenzuela proposes looking at the following determinants to determine labor union strength or decline: ${ }^{89}$ (1) density of union affiliation, (2) density of union affiliation in key areas of the economy, (3) historical characteristics of union organization, (4) the industrial relations system, in particular the degree to which unions can organize collective pressures to alter their respective labor markets, (5) the link between unions and one political party, and (6) the relative weakness of employers. ${ }^{90}$

Labor analyst Epstein also attempts to study the relationship between regime type and labor strength using one indicator: strikes. ${ }^{11}$ According to Epstein, strike activity or its absence can be seen as a direct indication of the union's ability to demonstrate its power against the government's ability to prevent the strike from occurring. ${ }^{92}$ Epstein collected statistical data for strikes in five Latin

${ }^{89} \mathrm{Valenzuela}$ is suggesting a framework in an attempt to find ways to measure strength and weakness of labor union in times of transition, but he acknowledges the complexity involved in this task. "What are the determinants of strength or weakness of the labor movement in times of transition? The answer to this question is complex." Ibid., 453.

${ }^{90}$ Ibid., $253-4$.

${ }^{91}$ Edward C. Epstein, "Austerity and Trade Unions in Latin America," in Lost Promises. Debt, Austerity, and Development in Latin America, ed. William L. Canak (Boulder, Co: Westview Press, 1989). This literature is connected with the literature previously analyzed in section II.

${ }^{92}$ Ibid. 
American countries (Argentina, Brazil, Chile, Mexico, Peru, and Venezuela) from 1976 to 1984. Epstein looked not only at number of strikes, but at the number of strikers, ${ }^{93}$ concluding that the general patterns in recent years is of decline (less strikes and less people going on strike). ${ }^{94}$

The literature presents two hypothesis to explain strikes: the economic and political hypothesis. Epstein tested both. Under the economic hypothesis, strikes are seen as a response to the economy:

Union leadership is seen as pragmatic, calling strikes in times of improving economy when employers might be more likely to grant wage increases, but yielding to economic realities during times of recession...therefore, years of austerity with lower wages and higher unemployment should correspond to times in declining strike activity. ${ }^{95}$

statistically, Epstein could not prove the relationship between wages and number of strikes, but his analysis shows a strong correlation between rising unemployment and declining strikes.

${ }^{93}$ Epstein considers that this number "indicate[s] the general mass support normally called by the union leadership;" (Ibid., 171) however, McGuire measures the size of the strike by the level of the union leadership at which the strike is called. According to McGuire, trade unions in Argentina are organized along industrial rather than craft or enterprize lines so it makes more sense to use this number, McGuire, "Union Political Tactics," 1 .

${ }^{94}$ Epstein, "Austerity and Trade Unions."

${ }^{95}$ Ibid. Also see Roberto P. Korzeniewicz, "The Labour Movement and the state in Argentina, 1887-1907," Bulletin of Latin American Research 8, no.1 (1989):25-46. Korzeniewicz analyzes labor at the beginning of the century. His hypothesis is that labor unions strike in prosperous economic situations and not when they may lose their jobs because of economic problems. 
Under the political hypothesis, the central issue is related to the union leader's perception of state responses to strikes. 96 The "possibility of coercion's being used against strikers, in turn, relates to the nature of the regime in power." Epstein used "official control,-itself based on the regime type and the efforts by those running the state to restrict trade union behavior-[as a] ...reasonable predictor of the number of strikes." 98 Epstein listed four regime types according to their coercive nature against labor: (1)populist democratic, (2) conservative democratic, (3) inclusionary or populist authoritarian, (4)exclusionary or bureaucratic authoritarian. 99 According to Epstein's study, the greater the control, the less strikes (the correlation is not as strong between control and strikers). Because of the difficulty to operationalize regime type, Epstein found the economic hypothesis to be more conclusive.

Labor decline can be defined by the loss of political and economical power. The following illustrates the sources of political and economical power:

POLITICAL POWER *strike

${ }^{96}$ This is related to Valenzuela's classification of regimes. Epstein, "Austerity and Trade Unions," 178.

$$
\begin{aligned}
& { }^{97} \text { Ibid. } \\
& { }^{98} \text { Ibid. } 185 .
\end{aligned}
$$

${ }^{99}$ Epstein listed the regime $1-4$ from least to most coercive. BY populist, the author means a regime that has a strong link to labor, among other key actors, while by nonpopulist, the author refers to a regime that views labor as a "probable enemy." Ibid. 
ECONOMIC POWER

*internal unity

* degree to which unions can organize collective pressure to alter labor markets

* control of the social security funds * member affiliation

*density of union affiliation in key industries

VII. CONCLUSION

The dual processes of democratization and economic reform challenged Latin American scholars to provide a hypothesis to explain the "new matrix" developed under neoliberalism. The peculiar political arrangements drafted by the governments to implement the reforms had consequences on civil society in general and on labor in particular, because labor is the main actor displaced by neoliberal arrangements. The government of Carlos Menem in Argentina is representative of this situation.

Menem's "neoliberal political project" (in Rosario Espinal's terms) seeks "to modify traditional populist alliances" by placing the market at the center of the project and displacing labor. At the same time, Menem's neoliberal "policy-making" was imposed "to cure economic ills with little regard for popular needs." His economic reforms shared the features of the Washington consensus: privatization, liberalization of the economy, wage freezes, budget cuts, and deregulated labor market reforms. As a result, the CGT lost political and economic power. To successfully implement the reforms, Menem had to break the structure of the labor unions through several mechanisms of control. 
Following Davila's framework ${ }^{100}$ as explained in the introduction, this thesis will link the consequences of neoliberal reforms (such as unemployment, low wages, and growth of the informal sector) to the decline of the economic and political power of the CGT. Chapter two describes in detail the external factors, based on Dávila's classification: the globalization of the economy; the role of the IMF, the world Bank, and the United States; and, President Menem's economic reforms. Chapter three analyzes the mechanism used by Menem to neutralize labor, while chapter four describes and assesses the effects of such reforms on the CGT, as well as the CGT's responses. Finally, chapter five draws general conclusions on neoliberalism and labor unions in Latin American which can serve as a conceptual framework for further scholarly research on the relationship between political and economic structures and processes in this region.

${ }^{100}$ Dávila looks at the internal and external factors affecting the labor union decline. External factors included in this thesis are: the government and its capacity to implement economic and political reforms, including the "selecting dismantling of the welfare legislation;" the economic situation; and, the international actors. The internal factors include: the history of the CGT, the organic structure of the CGT, the leader's political culture, and, the relation between the leaders and the file and rank workers as well as their relation with the population in general. 
CHAPTER TWO. THE ECONOMIC REFORMS.

Venidos a menos...somos un país atrasado, con una bajísima participación en el concierto mundial, aislado geograficamente, con una economia estancada, y crecientes sectores de pobreza. Argentina atraviesa una crisis que necesitaba de esta ley de emergencia nacional. El presidente Menem no pudo haber venido más a tiempo para salvarnos.

Peronist Senator Romero when passing the Emergency Law

\section{INTRODUCTION}

President Alfonsin's attempt to introduce austerity measures and economic reforms ultimately failed because he was unable to form the political alliances necessary to initiate them. Consequently, he was forced to resign six months before completing his term, turning the government over the newly elected President Menem. When Menem assumed the presidency on July 8, 1989, his main task was to overcome the economic crisis left by the previous administration.

Menem's attempts to implement the economic plan faced initial distrust and opposition. His economic ideas had been a mystery during his electoral campaign. The general perception, however, was that he would return to traditional Peronism. Once in power, contrary to this expectation, Menem "embarked on a [neoliberal] program involving fiscal restraint, wage repression, and economic liberalization."

Menem's economic plan brought inflation down, increased the gross national product (GDP), attracted foreign investment, and stabilized the economy. However, this did not

${ }^{1}$ Cardoso, Latin America's Economy, 197. 
bring immediate economic recovery to Argentina. Menem was able to successfully implement the reforms once he was able to control labor and establish alliances with the conservative right, who supported the reforms. The so-called "Argentine miracle" came when Cavallo assumed the Ministry of Economics.

This chapter describes the Argentine economic process as it relates to the CGT's economic and political power. ${ }^{2}$ For methodological purposes, the chapter is divided into the following sections: (1) globalization of the economy and its impact on Argentina; (2) the role played by external agents in the process of economic reform including the United states, the IMF, and the World Bank; (3) the economic background; (4) Minister Cavallo's stabilization plan; and (5) the measures adopted by the government to increase the flexibility of the labor market.

II. THE GLOBALIZATION OF THE ECONOMY-IMPACT ON ARGENTINA

In the 1980s, the resurgence of conservatism has become "global," "interdependent," and "transnational" in scope, as the basis of a "new international consensus." ${ }^{3}$ The United states lost its hegemonic role while western political economies experienced a gradual transition from "embedded liberalism toward more liberal orthodox economic

${ }^{2}$ The political process that accompanied the economic reforms are explain in detail in chapter three.

${ }^{3}$ Borón, "Becoming Democrats?," 2. 
arrangements."4 In the economic arena, transnational corporations replaced traditional multinational corporations (with headquarters in one country and subsidiaries in others) allowing the free circulation of capital, products, and consumption patterns across borders. A global "revolution in information, technology, telecommunication, and transportation"s increased the competition among the industrialized nations to extend toward new markets with lower trade barriers.

In this context, much of Latin America attempted to integrate itself into the world economy through marketoriented reforms. Argentina was no exception. ${ }^{6}$ Both President Alfonsin in 1983, and President Menem in 1989, introduced economic adjustment measures to stabilize a country suffering from de-industrialization, inflation, speculation, impoverishment, and a huge external debt left by the military

${ }^{4}$ Aldo Vacs argues that the 1970 s marked the end of the political order established after WWII. Powerful private actors, such as multinational corporations and international banks, took advantage of this unregulated era becoming key actors in the new international order. Aldo Vacs, "Convergence and Dissension: Democracy, Markets, and structural Reform in Global Perspective," (Paper presented at the conference on "Democracy, Markets, and structural Reforms" Buenos Aires, March 1992), 7 .

SVacs, "Authoritarian Breakdown,"13.

${ }^{6}$ Borón argues that Latin America's answer to the new international order is no surprise. He says: "knowing the traditional vulnerability of Latin American external influences, it is not difficult to conclude that these nations could hardly have resisted the strong movement towards the Right experienced throughout the capitalist world." Borón, "Becoming Democrats?," 5 . 
dictatorship during "the lost decade."7

Although there is no consensus of what adjustment represents (and the policies vary depending on the concept used), there is a general acceptance that "it can be broadly defined as the adaptation of consumption patterns, the reallocation of resources, and the changes in sector accumulation necessary to recover sustained growth in the face of a more adverse external environment." 8 The focus of structural adjustment policy is to restore the external balance of country in a way that the reallocation of resources minimizes short-term productivity losses in order to stabilize the economy and prepare it for further growth. 9

Traditionally, the IMF sponsored stabilization and adjustment plans asking for the implementation of orthodox adjustment measures, but adjustment in Latin America (and also in Argentina) was implemented in some cases through heterodox measures and in others, through orthodox measures. William Smith summaxizes orthodoxy:

As advocated by the IMF, orthodoxy is premised on a commitment to market-based solutions and the rolling back of "excessive" state intervention in the economy. IMF

${ }^{7}$ The term "lost decade" was first used by Latin American planners at the U.N. Economic Commission on Latin America and the Caribbean. The term refers to the 1980s, when military dictatorships spread throughout Latin America, borrowing excessive money, assuming that interest rates would stay low. "Latin American Economies Wither," The Miami Herald, 10 september 1989.

${ }^{8}$ Marcelo Selowsky, "World Bank Lending for structural Adjustment," Finance and Development v.24, no2 (June 1987):7.

${ }^{9}$ Ibid., p.16. 
orthodoxy also prescribes closer integration of peripheral economies into international financial circuits and trade and capital regimes. Accordingly, the principal policies of IMF adjustment programs aim to (1) correct the external trade deficit and stabilize international reserves at safe levels; (2) curtail and eventually eliminate the public-sector deficits; and (3) bring inflation under control. ${ }^{10}$

Heterodox packages, on the other hand, also are directed towards decreasing inflation and stabilizing the economy. Unlike orthodox economists, heterodox economists believe the state plays a strong role as regulator, at least in the beginning of the economic transformation, until replaced by markets. In general, governments that use heterodox measures establish unilateral payment of debt and do not comply with the IMF prescriptions in an attempt to avoid recessionary consequences for the poorest sectors. ${ }^{11}$

Regardless of whether the new Latin American democracies resort to heterodox or orthodox packages in the hope of making their economies more efficient, both measures are extremely costly and controversial. Generally, the packages are drafted by technocrats who are concerned with efficiency issues. The implementation of these neoliberal policies has important political and social implications that are often not considered by the policy makers.

Assuming that democracies, in their transitional phase, can blame previous authoritarian governments for their

${ }^{10} \mathrm{Smith}$, Authoritarianism, 274. Also see cardoso, Latin America's Economy.

${ }^{11}$ Ibid. 
necessity to implement austerity measures, as time passes, more than just rhetoric is needed to successfully carry on stabilization programs. Democratic leaders need stable coalitions in order to avoid social conflict. Since the economic measures tend generally to be severe, the executive branch needs lasting political pacts or coalitions.

If alliances fail or it is not possible to pact with the different sectors of society in order to implement such unpopular measures, three situations may happen: (1)The economic policies may fail because of the impossibility of crafting alliances with the different sectors of society (e.g. President Alfonsin), (2) the economic policies are implemented through undemocratic tools (e.g. President Menem's decrees); or, (3) the economic policies are implemented through authoritarian mechanisms (e.g. Fujimori's autogolpe).

Neoliberal measures are unpopular, especially among the labor class, and democracy is not sufficiently stable to implement them in a successful manner without neutralizing labor opposition.

The cases of President Alfonsin and President Menem illustrate these two different approaches: Alfonsin resorted to heterodox measures while Menem implemented traditional IMF orthodoxy. President Alfonsin distanced himself from the opposition and from the international finance community. Miscalculating that economic reactivation would follow the 
democratization process, ${ }^{12}$ he suspended all debt payments on the principal and delayed interest payments, resorting to more "bridge loans and rescheduling."13 In 1985, the Alfonsin Administration implemented an adjustment plan known as el plan Austral. Conceived as an heterodox strategy, the Austral Plan shocked the economy, reducing inflation and freezing all macroeconomic indexes. ${ }^{14}$ Public confidence and positive expectations aided in the Austral Plan's short term success.

In the long run, shortening the fiscal gap between revenues and expenditures and correcting the pervasive structures in which inflation works became imperative. ${ }^{15}$ Without these underlying reforms inflation exploded by March 1989. The Austral, which had exchanged at seventeen australes to the dollar in February 1989, declined to almost two hundred australes per dollar in only four months. Panic speculation and massive capital flight "fed fears that price hikes for the year might surpass 10,000 percent,"16 indicating the complete failure of Alfonsin's economic agenda. Inheriting the legacy

${ }^{12}$ Alfonsin came to power with all the legitimacy given by the a majority of the citizenry votes.

${ }^{13}$ Ibid. , 276.

${ }^{14}$ The fiscal deficit dropped from 10 percent to 3 percent of the GDP and in November 1985, inflation dropped to its lowest point of 1.9 percent. Ibid., 264 .

${ }^{15}$ Adolfo Canitrot, "La destrucción del estado Argentino y los intentos posteriores de reconstrucción," (Paper presented at the Conference on "Democracy, Markets and structural Reforms"), 19 .

${ }^{16}$ Ibid. , 276. 
of Alfonsin's failed reforms, President Menem took office in 1989 to carry on a neoliberal reforms, following IMF orthodoxy.

III. THE UNITED STATES, THE IMF AND THE WORLD BANK

Pressure to implement stabilization measures came not only from the internal forces of Argentina, but from international forces. This does not imply that there is a conspiracy to perpetuate dependency (as many Marxist and dependista theorists argued) in Latin America, involving the United states, the IMF, and the world Bank. But it does highlight the existence of a consensus (the Washington Consensus, explained in chapter one) to continue sponsoring the implementation of austerity measures as the only alternative to solve the Latin American economic crisis. Austerity programs sponsored by the IMF/World Bank focus on macroeconomic variables postponing issues of poverty alleviation, redistribution, and worker rights for when the economy is balanced.

In the late 1980s, the international financial community reviewed policies implemented in response to the Latin American economic crisis. Instead of focusing on "how economic growth rates could be accelerated" (as they traditionally did), they questioned "how the development of those countries with increasing balance of payments imbalances could be restarted."17 They proposed that Latin America

\footnotetext{
${ }^{17}$ Riddell, Roger Foreign Aid Reconsidered (Baltimore: John Hopkins University Press, 1987):96.
} 
should depend on trade and not on aid.

Accordingly, President Bush announced his program of integration with Latin America in June 1990 known as the "Enterprise for the Americas."18 While announcing the program, he stated:

the three pillars of our initiative are trade, investment, and debt... we look forward to the day when not only are the Americas the first fully-free democratic hemisphere, but when all are equal partners in a free trade zone stretching from the port of Anchorage to the Tierra del Fuego. ${ }^{19}$

Under the Bush administration, Latin American governments, and particularly Argentina under Menem, believed that trade integration, debt reduction, and cooperation among the united states and the new democracies in the region would occur if the economies were adjusted. The idea of a free trade zone from the United States to Argentina, however, has been more of an ideal than a reality. ${ }^{20}$ "Whereas Latin America

${ }^{18}$ For a detail analysis of the influence on the Enterprise of the Americas announcement on Argentina see: La iniciativa para las Américas, un instrumento de transformación de la región en la década del '90. La Argentina en su contexto." (Buenos Aires: AMCHAM, CARI, CICYP, and FIEL, 1991).

19 "Remarks by the President on the Enterprise for the Americas," The White House, office of the Press Secretary (27 June 1990).

${ }^{20}$ As U.S. magazine editorial reads: "if there is an irony in this situation, especially vis-a-vis our southern Neighbors, it is that trade policy in Latin America is becoming more liberal than trade policy in the United States. The nations of Central and South America have unilaterally lowered trade barriers; our own trade laws are frequently a morass of inhibiting regulations. It's time that the United states stop congratulating itself on being the world's bastion of free trade, and get around to the painful task of acting upon its words." J.P.Faber, "Whose Walls?," US/Latin American Trade (July 1993):6. 
trade regimes have generally moved away from protectionist stance typical of import-substitution industrialization, United states policies have become more protectionist." ${ }^{21}$ As a result, Latin America continued to experience a strong reduction in world trade, a desperate need for capital, and minimal reductions of the debt. Latin America's share of the world trade declined to 3 percent by 1990, from 12 percent in 1960. For instance, Latin America's trade deficit with the United States in 1991 was of $\$ 900$ million, after a decade of $\$ 10$ billion of surplus with the US. Latin American and the Caribbean is the only region of the world where the U.S. experiences a trade surplus. European countries, for example, trade with Latin America but do not invest in Latin America; they invest in Miami. The United states has not invested large amounts in Latin America either. ${ }^{22}$

Latin America has never been a high priority for the United States, especially under the clinton Administration. ${ }^{23}$ While former president Bush seemed to pursue a cooperative policy toward the Southern Hemisphere, (e.g. the negotiations to create a North American Free Trade Area, NAFTA, among the United States, Canada and Mexico) the 1994 U.S. budget

${ }^{21}$ Roberto Bouzas, "United States-Latin American trade relations: Issues in the 1980s and Prospects for the 1990s." (Paper presented at the IPSA XV conference, 1991).

${ }^{22}$ Gregg Fields, "Europeans, not Latins, lead way in investment," The Miami Herald, 29 March 1993, sec. BM.

${ }^{23}$ Christopher Marquis, "Latin America fears U.S. wavering on trade," The Miami Herald, 29 March 1993, sec. BM. 
reflects a substantial reduction in funds for Latin America. ${ }^{24}$

Results of trade liberalization for Argentina have been mixed. On the one hand, as a result of trade negotiations, a free trade agreement between Brazil, Uruguay, Paraguay, and Argentina (MERCOSUR) was created in 1991 with the ambitious aim of establishing a common market by January 1995. Growing trade imbalance, however, is threatening the common market while "average tariffs have fallen 65 percent [and] trade among the four nations has soared... commerce between the two largest countries, Argentina and Brazil, has gone from a substantial trade surplus for Argentina to a burdensome trade deficit."25 The trade surplus is shrinking in Argentina, dropping from 8 percent of the GDP in 1990, to 3 percent of the GDP in 1991. Indicators suggest this trend will

\section{3 :}

${ }^{24}$ As the front page of a local newspaper reported on June,

despite Washington's promises not to turn its back on Latin America, U.S. economic and military aid to the region is headed for a nose dive in 1993-a reduction of at lest 50 percent since 1992. The cutbacks could jeopardize dozens of projects to stabilize nascent democracies and free-market economies in the region, including everything from police training and electionmonitoring programs to judicial reforms, U.S. officials and lawmakers said....overall, the reductions would signify a 50 percent cut in total aid to the hemisphere in just two years from 1.51 billion in 1992 to about 751 million in 1994. The Miami Herald, June 3, 1993.

25 "Mercosur Moves Forward. But problems remain including a growing trade imbalance between the two big nations," The Miami Herald 10 January 1993, sec. K. 
continue. ${ }^{26}$ The office of the U.S. Trade Representative suggested that Argentina, "despite a far-reaching trade liberalization program," needs more tariff reductions. Furthermore, they criticize "television and cable television piracy...charg[ing] that current legislation does not provide adequate patent protection" to increase U.S. trade with Argentina. ${ }^{27}$

In spite of the critics, capital is flowing to Argentina because of Argentina's relative stability. ${ }^{28}$ This relative stability permitted Argentina to enter the "Brady Debt Reduction Plan." The plan proposed by U.S. Treasury Secretary Nicholas Brady in 1989, "ask[ed] banks to forgive part of their loans to debtor countries in exchange for limited guarantees of repayment, financed by the World Bank and the

\footnotetext{
${ }^{26}$ Washington had a $\$ 33$ million deficit with Argentina in 1990. In 1991, the U.S. had a surplus of $\$ 758$ million. Argentina increased its imports with the United States in 73.8 percent. By 1992, imports increase 38 percent more than 1991. In 1991, exports were worth $\$ 12.1$ billion., while in 1990 they were $\$ 12.4$ billion; imports, on the other hand, were $\$ 3.1$ billion in 1990, increasing to $\$ 8.1$ billion. in 1991. The Economist Intelligence Unit (1992):23.
}

${ }^{27}$ "Trade Barrier Pockets dot Latin Nations," The Miami Herald 11 April 1993.

${ }^{28}$ Net capital inflow amounted to $\$ 5.1$ billion in 1991 , more than tripling the amount registered in 1990. A research firm made a study on international business climates, comparing eighty five countries. The firm gave Argentina an index risk of risk of seventy one (in a scale from 1-100, the highest the index the safest to invest). The same study gave Argentina in 1989 an index of risk of thirty eight. However, in a five-year outlook, the study considers Argentina a country "with a high turmoil risk, and an increasing transfer and investment risk." Political Risk Services. "Business Risk," The Miami Herald 29 March 1993, sec. BM. 
IMF." 29 From the twenty six countries supervised by the world Bank only seven countries owe less than five years ago. It is hard to predict if Argentina will gain significant benefits by entering into this debt reduction plan. As a popular Argentinean newspaper reported in April 1993, "the simple fact of Argentina's entering in the Brady plan does not solve the grave structural problems Argentina has experienced for over a decade. " ${ }^{30}$

IV. MENEM'S ECONOMIC REFORMS

When Carlos Menem assumed office, the inflation rate was 4,924 percent annually, consumer prices were increasing 3,610 percent per year, and wholesale prices rose even faster $(5,062$ percent annually). ${ }^{31}$ Argentina was in a state of political and economic chaos. To restore economic stability Menem implemented neoliberal reforms.

The first step toward neoliberalism was to appoint a conservative cabinet to support the reforms. ${ }^{32}$ Miguel Roig,

29 "El día después," Clarín 11 abril 1993, suplemento económico. Also, Cardoso, Latin America's Economy.

${ }^{30}$ Ibid.

${ }^{31}$ Smith, "State, Market, and Neoliberalism in Post Transition Argentina: the Menem Experiment," Journal of Interamerican Studies and World Affairs v.33, ne 4 , (Winter 1991):45.

${ }^{32}$ paradoxically, before assuming office, Menem said during his campaign:

Society needs a strong state, with a specific role and with a strong private initiative... some people see things too easy, they want to privatize state enterprise and want to leave 100,000 employees on the streets, they do not see the terrible social cost of such a 
former vice president of Bunge $y$ Born, Argentina's largest multinational corporation; Alvaro Alsogaray, from the traditional conservative party linked with the military; and, Domingo Cavallo, a technocrat graduated from Harvard, formed Menem's cabinet.

Menem passed two major legislative proposals to support his project: ${ }^{33}$ the ley de reforma del estado ne 23.696 (the state Reform Law, hereafter SRL) and the ley de emergencia nacional ne 23.697 (the State Emergency Law, hereafter SEL). ${ }^{34}$ It is important to describe these laws because they set the legal framework of the neoliberal project. The laws were

measure....Before saying that our enterprises have deficit, let's administer them properly with Argentinean pride!.... would ask the radical party what is the difference between them and Martinez de oz, because they want to implement the same orthodox measures applied by the monetarist.... I am suggesting to look at alternatives to favor ourselves and not the IMF...maybe with a moratorium on the external debt if necessary as suggested by the CGT....We can not side with any imperialism because it will mean the end of our nationalism and pride.

Eduardo Angeloz, though, the candidate from the radical party, who represented the "privatista" option, lost the elections. Gustavo Béliz, Menem. Argentina hacia el año 2000 (Buenos Aires: Editorial Galerna, 1986):50-115.

${ }^{33} \mathrm{O}$ 'Regan, "What has been done?," 23.

${ }^{34}$ Senator Romero, one of the peronist senators who elaborated the laws, justified them by saying: "It was necessary that precisely the justicialismo, the first movement that put the state to serve the interests of the nation, and not the interests of the business sector, the one that redefined the authentic role of the state, the movement that decided to pass this law." Paradoxically, neoliberal reforms are the antithesis of Peronism. Juan Carlos Romero, Ante la emergencia (Buenos Aires: Imprenta del Congreso de la Nación, $1990): 5$. 
approved by Congress with the support of the Peronist party and were reformed by decrees when Congressional support was not achieved.

The SRL was passed by Congress in August 1989. The law is divided as follows:

(1) reform of the state, administrative emergency, (3) privatization and participation of private capital, (4) private property program, protection of the workers, (6) emergency contracts, (7) concessions, and, (8) a plan of emergency employment. It declares a state of emergency for every aspect of the services, contracts, and finances supplied by any organism of the state (art 1) and gives the government the right to intervene in any such organism (art 2), naming acting directors to fire or lay off any public employee as needed (art 3). The SRL laid the foundation for the privatization or concession of state owned enterprises, listing the public enterprises that were up for sale. The SRL also introduced the notion of "emergency employment," making employment available when needed, and reduced the cases in which public employees had a right to receive compensation. ${ }^{35}$

Through the enactment of decree $435 / 90$ President Menem amended this law. ${ }^{36}$ The decree prohibited the Central Bank from financing any public deficit (art 1), declared that all

${ }^{35}$ This law was passed after long negotiations among the different congressional sectors. An analysis of the political alliances to pass the reforms are analyzed in chapter three.

${ }^{36} \mathrm{Mainly}$ because he could not reach Congressional support. 
company debts owed to the state were due and needed to be canceled immediately (foreign companies are exempt, art 3), suspended the payments of any debt contracted for the state (unless it was to a foreign institution, art 8), limited the amount of salary for state employees (art 20), established the need to renegotiate collective bargaining issues with the unions if state employees were involved (art 21), established forced retirement of any employees who had the necessary conditions to retire (even if those conditions were meet in two years, art 24,25$)$, and established a hiring freeze on every state position (art 27). The SRL was intended to reduce 25 percent of the state's expenses.

The SEL was passed by Congress on September 1, 1989. The first article of the SEL states: "the present law gives the discretionary power to the state to overcome the situation of collective danger created by the grave economic and social life in the country [emphasis added]." The law established the following measures: (1) suspension of every state subsidy, (2) reform of the central Bank (art 3), (3) suspension of 50 percent of the incentives to promote industries (Chapter four), (4) suspension of 50 percent of the incentives to promote mineral industries (Chapter five), (5) equal treatment for foreign and national capital if invested in productive areas (legalizing the deposits in dollars), (Chapter six), (6) a reform of the tariffs on imports (Chapter ten), (7) the state right to use any debt or money in deposits as needed 
(Chapter nine), ${ }^{37}$ (8) the state right to relocate, fire, or lay off its personnel as needed (Chapter eighteen); and, (9) the creation of a commission to reform the social security system (Chapter twenty two).

The legal framework and the pro-market reform cabinet was established during Menem's first months in office; however, the first year's economic reforms did not last because Menem lacked the political coalition to support the reforms. Menem needed to craft alliances with the strong business sector, with his own political party, with the political opposition, and with the military. He also needed to neutralize the labor movement. ${ }^{38}$

The first economic austerity plan, known as the Plan BB (orchestrated by the powerful Bunge $y$ Born corporation) reduced inflation and interest rates but did not stop the speculative behavior characteristic of a "culture of

${ }^{37}$ This measure translated into the controversial measure of January, 1990, to convert a majority of the deposits to dollars collecting $\$ 1,500$ millions with short term due. The Central Bank only paid to the investors with less than $\$ 500$, the others received a state bond (BONEX) in dollars, which could be cashed in 10 years with an interest rate of 6 percent annual.

${ }^{38}$ Menem's political arrangements as related to labor are described in chapter three. This thesis argues that to successfully implement neoliberal reforms, the government needs a weakened labor union organization and a government capable of controlling labor. This does not imply that labor is the only sector that needs to be controlled; governments needs to craft folitical alliances to support the reforms, especially with the strong business sectors called "the patria financiera" and the military. For more on this subject see: Acuña, "Politica y economía en la Argentina de los 90," and Gamarra, "Crafting Political support." 
inflation" of the strong business sector. In a country such as Argentina, used to hyperinflation, business and other sectors of society "act defensively on the rational expectation that inflation will either remain high or rise even more in the future." 39 Many companies benefitted from hyperinflation by using "capital generated by sales tax receipts (sometimes amounting to 60-70 percent of the final sale price for some goods, such as cigarettes) for short-term speculative investments in financial markets."40 when business saw that the reforms might threaten their profits, they "led a 'market coup' against the government policies that resulted in a new bout of hyperinflation." 41 The Plan BB failed in the summer of 1990. Economist Adolfo Canitrot expands on this $\operatorname{logic}{ }^{42}$

Canitrot argues that in their first stage, stabilization plans are popular because they link stabilization with a higher level of economic activity and an improvement in real wages as a result of a drop in inflation, as was the case with the Plan Austral. ${ }^{43}$ These policies are inherently weak, because they do not correct the inflationary structure, permitting the continuity of speculative behavior. Alliances

\footnotetext{
${ }^{39}$ Smith, "Neoliberal Restructuring," 6.

${ }^{40}$ Ibid.

${ }^{41} \mathrm{O}$ 'Regan, "What Has Been Done?, 20.

${ }^{42}$ Adolfo Canitrot, "La Destrucción del Estado Argentino." ${ }^{43}$ Ibid.
} 
are imperative to support reforms after the first successful stage. ${ }^{4}$ When stabilization is achieved, the government must generate resources to pay the external debt and spur economic growth. Taxes, an important source for government revenues, are unpopular both in the labor class and the business sector. In fact, as William smith acknowledges:

the dominant industrial, financial, and agro-export sectors of Argentina's fractious entrepreneurial class have consistently utilized their privileged position and enhanced structural power to 'up the ante' by demanding that the government immediately match its rhetoric with concrete deeds, particularly on such issues as (1) reduction of fiscal deficit, (2) ending price control, (3) introducing a favorable exchange-rate regime, and (4) introducing a heavier hand with organized labor... specific firms and representatives of these same groups (the patria financiera, reaping the fortunes of financial speculation, and the patria contratista, dependent on governmental largesse in dispensing contracts) view their own demands for state support as fully justified and, indeed, as the embodiment of economic rationality. on the other hand, state intervention on behaif of consumers, workers, the poor, or even of less efficient' business interests are deplored, if not decried, as 'wasteful subsidies' to be eliminated forthwith. ${ }^{45}$

Alliances with the business sector are essential to impose the reforms. To gain the support of business, canitrot argues, privatization is given in exchange for support for tax reform at a later stage. ${ }^{46}$ In the beginning of the reforms, business demands that resources should come from cuts in social expenditures, which creates labor opposition. This

${ }^{44}$ De Bruno, Rapporteur to the International Conference "Democracy, Markets, and structural Reforms."

${ }^{45}$ Smith, "State, Market, and Neoliberalism," 70.

${ }^{46}$ Ibid. 
opposition must then be neutralized as business support increases. Cavallo introduced the reforms by siding with the business sector, privatizing and neutralizing labor demands. This plan deserves to be analyzed in detail since it brought economic stabilization to Argentina.

V. THE SUCCESSFUL CAVALLO PLAN ${ }^{47}$

on January 1991, Domingo Cavallo was sworn in as Minister of the Economy. On April 1, 1991, he began the economic reform known as "The Cavallo Plan," which brought economic stabilization to Argentina. This plan stood on three pillars: ${ }^{48}$ (1) the stability plan known as the plan de convertibilidad or the convertibility plan, (2) state reform control, focusing on: (a)rationalization of public expenditures, (b) privatization, and (c) increased revenues and reform of the tax system; and (3)deregulation and liberalization of the internal market, including deregulation of the labor market.

The Convertibility plan meant that the Austral became freely convertible into dollars. With the support of "Congress [which] passed a law prohibiting the central Bank from printing money to cover budget deficits unless new

${ }^{47}$ With Domingo Cava110, a Harvard graduate and until then the Minister of Foreign Relations the implementation of the neoliberal measures started to work. For more on the failure of the first economic plans see: McGuire (1991), Smith (1991), and Acuña (1992).

${ }^{48}$ Silvia Sigal and Adolfo canitrot, "Interactions Between Market oriented Reforms and Democratic Consolidation," oversees Development Council (Argentina: First Draft for the Rio Meeting, November 9-10, 1991). 
emissions were fully backed by gold or foreign currency, "49 and personal savings deposits of over $\$ 500$ were frozen for eight years in exchange for bonds. The plan was risky, but it has survived with relative success until now. Should the price of the dollar go up, the central Bank has sufficient dollar reserves to put in the economy and stop the increasing price of the dollar. The Central Bank's reserves, which were calculated at $\$ 3$ billion, are blocked in order to pay the external debt.

To achieve internal price stability, Cavallo's plan increased taxes 30 percent on public services, adjusted public service tariffs upward (railroads, post office, water 25 percent, gas 50 percent, electricity 40 percent), eliminated specific tariffs on imports in favor of a general rate of 22 percent or 11 percent for basic imports, eliminated the indexing of prices, salaries, and contracts to inflation; and decreased interest rates from 44 percent to 22 percent annually. Cavallo's plan changed the denomination of the currency from australes to pesos, pegging the peso to the dollar.

The stabilization plan shocked the economy, reduced inflation from 4,300 percent in 1989-90 to 17.5 percent 1992, decreased the index of consumer prices from 27 percent in February to 1.8 percent in september 1991, and reduced the

${ }^{49}$ William Smith, "Restructuring Argentina," Hemisphere, v.4, ne1, (Fall 1991):23, 
foreign debt by $\$ 4$ billion from 1989 to 1991.50 After

stabilization was achieved, cavallo proceeded with the reforms of the state apparatus. The "rationalization of the state" meant severe budget reductions ${ }^{\text {si }}$ on social expenditures such as health, 52 education, poverty alleviation, ${ }^{53}$ infrastructure, along with a massive reduction in the highly unionized-public sector employment. ${ }^{54}$ since health and education are by law not transferable to the private sector, the protests of teachers, professors, and health employees have escalated

${ }^{50}$ Acuña, "Politica y Economia en la Argentina de los 90," 15. The first reduction of the Argentine foreign debt occurred as a consequence of Cavalio's Plan. Further reductions came as a result of entering into the Brady Plan previously discussed.

$\begin{array}{lcc}{ }^{51} \text { Fiscal Year } & 1981-1985 & 1990 \\ \text { Receipts } & 24,7 & 19,2 \\ \text { Expenses } & 37,0 & 23,5 \\ \text { Deficit } & 12,3 & 5,3\end{array}$

Canitrot and sigal," Interactions,"5.

${ }^{52}$ In 1991, a UNICEF report found that: "half of all Argentine children are poor and that half of the poor are children under the age of twelve suffering from malnutrition." Smith, "State, Market, and Neoliberalism," 67.

${ }^{53}$ Argentines leaving in poverty now reach $\$ 10$ million people out of a population of $\$ 32 \mathrm{million}$. In the mid 1980 , a survey of the suburbs of Buenos Aires with a total population of nearly 7.3 million people, showed that 31.3 percent people were "structurally poor" while 68.7 percent were considered "pauperized." These increasingly pauperized sector is form of working class and formerly middle class families who enjoyed a reasonable standard of living in the past but "because of prolonged downturn in the economy, had been pushed into a condition of poverty frequently indistinguishable from that of structuraliy poor." Ibid., 69.

${ }^{54} \mathrm{Smith}$ reports that 70,000 jobs were eliminated in Caval10's six first months and 130,000 cuts were announced for the next year. Ibid., 64. 
against a government that appeared to be sacrificing them and the social welfare system in the interest of economic stability. No major governmental results were achieved since these protest do not have the support of the whole CGT. ${ }^{55}$

The second part of Cavallo's state reforms was the privatization of state enterprises. Argentina sold several of its major state-owned companies in a short period of time, including : two of the main TV stations and radios, 10,000 kilometers of federal highways, Argentine Airlines, the stateowned phone company, state interests in five petrochemical operations and many other subsidiaries, the spectacular LlaoLlao hotel in Bariloche, controlling shares for the nationwide natural gas pipeline, four rail freight lines, the Tandandor state shipyards, water and sewer services, the electric power services, the equestrian racetrack, the metallurgy firm Somisa, and subsidiaries of YPF, which is the national petrochemical. ${ }^{56}$ The sales gave the government cash to stabilize the economy and reduce part of the external debt because it was required that buyers should partially pay in

${ }^{55}$ President Menem has recently publicly recognized this situation on January 1993 announcing a plan to assist with $\$ 1,500$ annually to aid (in Menem's terms) "the ones who suffered more under hyperinflation and now austerity." "Menem anuncia vasto plan social," El nuevo Herald 8 January 93. coincidentally, 1993 is the year of elections. For more on these protests see chapter three.

${ }^{56} \mathrm{Still}$ in progress are the sales of YPF, the ports and airports, the nuclear energy plan, insurance firms, the Rio Negro Bank, agribusiness, and various hydroelectric plants and roadwork. Dan Newland, "The Big one," U.S./Latin Trade (July 1993): 58 . 
cash and partially pay by assuming Argentine debt on the Argentine secondary market. It also favored the strong business sector. Without much internal capital to buy the state enterprises they stayed in the hands of a few strong businesses, increasing monopoly. ${ }^{57}$

The third part of the state reforms was tax reform. Caval10 increased the value added tax (VAT) from 16 percent to 18 percent, standardized invoicing to ease the implementation of the VAT, and implemented reforms in legal and administrative procedures to combat tax evasion. ${ }^{58}$ A profound tax reform affecting every sector of Argentina's economy is still to come. The tax reform package is still waiting congressional approval and the government has not put serious pressures to have them pass because of strong opposition.

Finally, the cavallo reforms emphasized economic deregulation. To liberalize foreign trade and make industries more competitive, the government eliminated all import and export quotas, freed all professional fees and commissions, disbanded ten government organizations that controlled

${ }^{57}$ Acuña, "Política y economía en la Argentina de los 90." A majority of the state-owned enterprises were sold to direct buyers. The only two exception to this rule was the state telephone company and YPF. In the first case, "30 percent was marketed on the local Bolsa." In the second case, "Cavallo discouraged the use of credit to purchase YPF shares on the local stock market." For more on the YPF sale: Newland, "The Big one."

${ }^{58}$ As Acuña pointed out until now the one hundred biggest corporation in Argentina do not appear in the list of the one hundred biggest tax payers. Acuña, "Politica y economia en la Argentina de los $90, " 16$. 
critical industries, permitted the open importation of pharmaceutical drugs and removed vast pensions from labor union management. ${ }^{59}$

VI. THE FLEXIBILIZATION OF THE LABOR MARKET

Labor reforms are an integral part of economic reforms because they affect business competitiveness. Business has traditionally argued for a more flexible and transparent labor market that would allow to lower prices. For neoliberal reforms to succeed, the corporatist labor structure needs to be dismantled to please business demands. Cavallo made labor reforms a key part of his economic agenda since 1991 but only recently they have produced significant results. ${ }^{60}$

When Menem introduced the SRL, he requested from the unions a two year strike-free pledge, a plan to allow for early retirement for public service employees, a freeze on all government hiring, and a plan to make labor markets more flexible. ${ }^{61}$ He advocated these reforms to "end the rigidity

${ }^{59}$ U.S. Market Access in Latin America: Recent Liberalization Measures and Remaining Barriers, (USITC Publication 2521, June 1992).

${ }^{60}$ Labor reforms are an integral part of the economic reforms. In Economic Reform Today, a publication of the U.S. Chamber of Commerce, Mauricio D. Perea, assistant editor recommends: "Reforms in the legal system should emphasize the creation of a marketplace that functions smoothly and efficiently for both producers and consumers...labor laws designated to protect workers may make it difficult for employers to dismiss unwanted employees. These laws often have the unintended effect of restricting job creation by making employers reluctant to hire new employees." summer $1992, \mathrm{v} .2$, ne 3 .

${ }^{61}$ O'Regan, "What has Been Done?," 24. 
of the union contracts that employers complained inhibited them from hiring on a trial basis," ${ }^{62}$ and to lower high labor costs which hindered market competition. ${ }^{63}$

On November 1991, the government passed the Employment Law (Law 24.013) and the law regulating Job-Related Accidents Law (JRA or Law 24.028). The government also reformed the collective bargaining system and the social security system. The fundamental aim of the employment law was to lower labor costs by "making the hiring of new personnel, both permanent and temporary, as well as the layoff of superfluous workers and employees less rigid and expensive." 64 The law allowed for workers to be employed temporarily on contract for up to two years, without the need for union approval. ${ }^{65}$ Furthermore, temporary contracts allow employers to: (1)hire part time employees during weekends without having to pay overtime (traditionally, business and stores are closed saturday afternoons and sunday), and (2)hire temporary employees for specific jobs that only need temporary workers. Once the worker's contract ends, he or she should be hired permanently or forced to leave, without benefits or possibility of

\section{${ }^{62}$ Ranis, Argentine Workers, 212.}

${ }^{63}$ In 1975 wages and salaries accounted for 53.8 percent of GNP, in 1983, this figure had slid to 41 percent, by 1990, it declined to 30 percent of GDP. Labor's hare in national income has only continued to shrunk under Menem. Argentine Business News, 23 March 1992, v.1, ne3, p.7.

${ }^{64}$ Ibid.

${ }^{65}$ Traditionally, any new contractual arrangement had to be approved first by the labor unions. 
contract renewal. $\$ 6$

While temporary employees are under contract, the employer pays 50 percent of the normal pension and social welfare contribution, compared to the traditional 100 percent contribution. If the worker is under twenty four years of age, and is terminated during the life of the contract, the employer is not obligated to pay any severance payment. ${ }^{67}$ The reforms reduced vacation days to a maximum of twenty two days in the year (down from thirty five days) and established a uniform forty days' advance notification of dismiss compared to the present requirement of thirty to sixty days.

The fundamental aim of the JRA was to limit the amount of severance payment, establishing a ceiling, or maximum amount to be paid in case of job-related accidents or termination of a job. It also limited what is considered a job-related accidents, and in case of disagreement, the JRA's tendency is to favor the position of business. ${ }^{68}$

To dismantle the corporate Argentine labor structure the government passed collective bargaining reforms. By reinstating the Law on Labor contracts the government attempted to flexibilize the hiring and firing of workers. At the same

${ }^{66}$ Microsemanario informativo, April 1993. Online service information received thorough Bitnet Internet connected computers. The Argentine mailing list could be accessed by any computer with a modum. SMTP\& "arg-adminejournal. math. indiana. edu."

${ }^{67}$ 'Regan, "What has Been Done?,"24.

${ }^{68}$ Argentine Business News, 9. 
time Menem, abolished the separate collective bargaining arrangements that had been created for banks and the maritime industry, which had many regulations. These sectors are now forced to adhere to one type of collective bargaining arrangements ${ }^{69}$ involving the unions, the workers, and the businesses in an attempt to deregulate the process.

Contrary to this de-regulatory collective bargaining attempts, decree 1.757 on collective bargaining issues established that any clause linking labor conditions distortive of the productivity or the normal development of business interest, lacked legal effect. To complement this decree, decree 1334 forced unions to negotiate salary increases based only on productivity, so that wage increases are not longer linked to prices. In this way, government left wage increases in private hands, but established strict governmental control on the type of salary increases labor could negotiate.

In general, collective bargaining reforms aimed at removing control of labor demands from unions, and placing it with private industry. These reforms follow the trend of the industrialized nations, in which the government is not part of the labor-owners negotiations. The reforms affected the structure of the labor composition and unions, reforms that will be analyzed in detail in chapter four.

Finally, on May 1, 1993, the government signed the law on

${ }^{69}$ Noticiero informativo. 
social security and retirement plans. The reforms established that: (1) employees are no longer forced to contribute part of their wages to the unions that represent them; (2) unions will no longer be in charge of collecting or controlling social security deductions and will no longer have control over it; (3) retirees who are presently receiving their money from the state, may continue to do so; (4) workers over forty five years old will contribute to the state and will get their retirement money from the state; (5)workers under forty five will be under a mixed system (explained in the following paragraphs); (6) women and men must be sixty five years old to perceive benefits; and, (7) the amount of social security benefits for handicap workers will be drastically reduced. ${ }^{70}$

The social security system and the retirement system will consist of a private and public system. The owners contribution will finance basic needs. These funds will be administered by the state and will consists of an equal amount for each worker. ${ }^{71}$ The money that come from the employees will go to a private entity created specifically for this purpose called AFJG (Administradora de fondos de jubilación privada), which will handle the distribution of the money without state guarantee. The social security system only protects workers from the formal sector, since workers from the informal sector

\footnotetext{
${ }^{70}$ Acuña, "Politica y Economía en la Argentina de los $90, " 17$.

71 "De la seguridad social a la bolsa," Mercado ne 893, March 1992, p.30.
} 
do not contribute. Informal sector workers may be able, though, to receive some minimal support from the state. ${ }^{72}$

VII. CONCLUSION

President Menem inherited a country with severe economic problems. Forced by the internal economic situation and by international interests, Menem introduced austerity measures which affected not only the economy but, most importantly, affected people and social institutions. The reforms stabilized the country (higher GDP, reduced inflation), ${ }^{73}$ but increased the concentration of income in fewer hands, ${ }^{74}$ reducing labor's share of national income. ${ }^{75}$ The reforms aimed at displacing labor and placing markets at the core of the economic and political agenda.

Liberalizing the economy, privatizing, and tying wages to productivity clearly favored the interests of business

${ }^{72}$ Ibid.

${ }^{73}$ As Andrés Oppenheimer, a columnist for the Miami Herald says: "Argentina está muy bien, pero no asi los Argentinos." oppenheimer, "Pese a mejoria económica, inflación agobia a argentinos," El nuevo Herald, 10 May 1993, sec. 4A. For more on economic indexes refer to table one.

${ }^{74}$ In 1960, the top 10 percent of income recipients received 39 percent of the GDP, by the end of the 1980 s the share of this top 10 percent had risen to 46 percent of the national income, a figure much closer to the latin American norm. See Smith, "State, Market, and Neoliberalism," 68 .

${ }^{75}$ In 1975, wages and salaries accounted for 53.8 percent of GNP, by 1990 it declined to 30 percent of GNP. The price of the "canasta familiar" (family basket which is the minimum amount required by a family to leave) per month is of $\$ 1,300$, while the average wage is $\$ 300$ and the average pension is $\$ 150$. "Desigual, pero alentador panorama económico de Latinoamérica en 1992," El nuevo Herald, 1 January 1993, sec. $5 B$. 
sectors. ${ }^{76}$ Once the economy was stabilized, labor costs were reduced to make goods and services more competitive. 7 while these economic changes may have been initiated with the intention of enhancing productivity and the international trade balance of payments, they had another consequence: a direct attack on unions as economic and political institutions within Argentine society. Labor unions suffered economic losses in the form of reduced affiliation and social security funds taken away from its management. To successfully implement the reforms aimed at diminishing labor power, Menem had to break the structure of the labor union through several mechanisms of control. ${ }^{78}$

The next chapter will analyze the political factors that allowed the introduction of these neoliberal reforms. What

${ }^{76}$ Dávila, while analyzing the $\mathrm{COB}^{\prime}$ s situation in Bolivia, concludes that under the "Nueva Politica Economica," the political and economic power consolidated under the private enterprises through the parties from the right. The political and economic consolidated power was one of the main reasons for the $C O B^{\prime} s$ decline as a political actor. A similar situation was experienced within the CGT and will analyzed in chapter four. Dávila, "Apuntes," 20.

${ }^{7}$ Clarín, a popular Argentinean newspaper reported on April 1993 that from 1991 to the present labor cost increased 16 percent, reaching the amount of $\$ 860$. In the 1980 s, the cost was only of $\$ 400$. Businessmen complained to the government that "it is impossible to compete with these big labor costs." In Argentina, contributions to cover health is around 14 percent while in Chile for example is only 7 percent. Another explanation for such large cost were the increases in nominal salaries during the first months of the convertibility plan. However, with the various measures taken by the government, labor costs are diminishing. Patrick Adam, "Fuerte aumento en los costos laborales," Clarin 6 April 1993.

${ }^{78}$ As will be shown in Chapter three. 
mechanisms were employed by President Menem to neutralize the logical labor union opposition? How did he neutralize labor opposition? What new political coalitions were formed in support of the economic reforms? 
CHAPTER THREE. MENEM AND THE CGT-CO-OPTATION AND CONTROL

Quizas ni los propios dirigentes gremiales alcancen a comprender tanta indiferencia desde el Gobierno. Ellos mismos no han entendido que, hoy por hoy, los sindicatos como las Fuerzas Armadas han dejado de ser una referencia obligada para la estructuración del poder en la Argentina.

clarin Editorial, September 1991

I. INTRODUCTION

This chapter summarizes Menem's political tactics to win the elections with labor support, and his subsequent capacity to implement neoliberal reforms, neutralizing labor's opposition. To reiterate the central hypothesis of this work, the decline of the CGT resulted from the implementation of neoliberal reforms. To successfully implement these reforms, Menem broke the structure of the labor movement, dismantling the CGT's corporatist structure through several mechanisms of control. Implementing reforms required leadership skills and the ability to "craft" electoral alliances (to win the elections) and governing alliances (capable of supporting the reforms). For analytical purposes, this political process can be divided into four parts: building a broad, even contradictory electoral coalition, including the CGT, (2) dividing and co-opting the CGT following the elections, (3) instituting the neoliberal reforms by controlling and co-opting the CGT, and permanently weakening the CGT by controlling and outlawing strikes.

II. BUILDING THE ELECTORAL COALITION 
Menem's 1989 presidential campaign was shaped by contradictions. While governing the province of La Rioja, prior to being elected president, Menem argued for strengthening the role of the state, increasing wages (called el salariazo), recovering the Malvinas, and returning to traditional populism." As one newspaper stated: "there are no doubts at this moment that Menem is the statist option, since he is already speaking of new ministries and official organisms. This is what he wants: more bureaucracy and bureaucrats." "2

At the same time, Menem included in his electoral platform people from the right. Menem suggested that if elected president, he would offer the Ministry of Economy to technocrats trained in U.S. universities, such as Domingo Caval10, a Harvard graduate, Jorge Domínguez, a Duke graduate and connected to the political right, and Eduardo Bauza, a successful businessman. These candidates supported views

The international press described Menem as a obscure candidate. "In normal circumstances Menem would be the least likely choice as leader of a country attempting to retake the road of democracy. Early in his political career, Menem did his utmost to resemble Argentina's provincial war lords-the gaucho caudillos who fought for their fields and against Iiberalism. Today he has given up his gaucho dress for everyday wear but still retains a fierce mane of hair with leonine whiskers and sideburns. The son of syrian immigrants who became wealthy landowners in the poor Northwestern province of La Rioja. Carlos Menem was almost a walking caricature of a rough-riding montonero, a gaucho of Argentina's once wild northern frontiers." Robert Cox, "Argentina May Get Government It Deserves," The Miami Herald, 21 May, 1989.

${ }^{2}$ Hugo Gambini, "El milagro," Redacción, 11 April 1989, 
contrary to traditional Peronism such as: fiscal deficit control, balance of payments imbalances, foreign investment, state intervention reduction, and coming to terms with the IMF. ${ }^{3}$

Using a populist rhetoric but negotiating positions with the conservative right, he gained support from the working class and the poor, who were traditionally Peronist, and the business class, who foresaw a change. Menem's political platform included candidates from orthodox Peronism, ${ }^{4}$ the leftist FREJUPO (that advocated debt default and state

${ }^{3}$ Menem had neither a clear economic plan at the time of the elections nor a cabinet formed. While Domingo Cavallo wanted to privatize and limit the role of unions, other economists such as Samuel Muzykansky and Jorge Domínguez spoke of giving priority to what the unions and the big enterprises agreed on. Fabián Mauri and Luis Micou, "Los economistas de Menem," Gente (May 1989): 45 .

${ }^{4}$ The Peronist party was experiencing several internal divisions. The Peronist renewal wing, with governor Antonio Cafiero leading it, could not distinguish itself from the radical party of Alfonsin. The second sector was a new movement called the Menemistas leaded by Carlos Menem. Contrary to what James McGuire is suggesting, Menem originally came from the most orthodox sectors of the Peronist party. Later, he found links with the Group of the 15, a progressive faction of the CGT, and sectors of the Peronist renewal wing. James McGuire, "Political parties, Social Forces, and Democracy in Argentina" (Paper presented for the conference on Parties and Party Systems in Latin America Kellog Institute for International studies, University of Notre Dame, Notre Dame, Indiana, October 21-23, 1990), 45 .

SThe FREJUPO (Frente Justicialista de Unidad Popular) had several leftist sectors, such as the Christian Democrats, the MID (Movimiento de Integración y Desarrollo), part of the PI (Partido Intransigente), the Movimiento patriótico de Liberación, the Partido de la Izquierda Nacional, and factions of the socialist and communist parties. "How can you conciliate leftist points of view, such as the one of the FREJUPO, with economic suggestions given by Cavallo, Curia, or Musikansky, which have great acceptance among Peronism? or, 
intervention), modern sector of Peronism (the renewal wing), extra-party members linked with the conservative right and the military (who advocated free market reforms, and payment of the external debt), and members of the CGT.

To gain the support of the CGT, Menem negotiated with every sector within the labor movement. His electoral strategy towards the CGT was also contradictory, but achieved the support of the whole labor movement. He appealed to traditional Peronism and suggested a return to labor cogovernance to gain the support of the most orthodox sectors of the CGT, who had always been Peronist. Based on this assumption, Saul Ubaldini, General Secretary of the CGT at the time of the elections, presented a program consisting of a moratorium on the external debt considered acceptable by Menem.6

Menem also negotiated with the Group of the 15. The

what will be the position of the different sectors in FREJUPO in two fundamental issues: the Malvinas and the Military? And the external debt?... the truth is that the Peronists switch towards the right, which found allies in the military and the business sector, no longer will match with leftist sectors, such as FREJULI." Julio César Moreno, "Caballos frescos para una nueva etapa," La voz del interior, 19 February 1989.

TMenem was asked during the campaign: -And the moratorium? Is it likely that it will happen? Is the position of the CGT an extreme position?" Menem answered: "On the contrary, the position of the CGT come from long hours of study. I can testify this. Personally, I believe that the moratorium is an extreme position but it is a possibility that we should not disregard. If the North does not understand reasons, we should tell them 'let us grow and come back in ten years." Gustavo Beliz, Menem. Argentina hacia el año 2000 (Buenos Aires: Editorial Galerna, 1986), 51. 
Group of the 15 was a group within the CGT that wanted to itself distance from traditional Peronist unionists. Instead of governmental confrontation, this group sought a dialogue with the Alfonsin administration and the business sector to achieve a social pact.' Through the Group of 15, business sectors funneled money to Menem's campaign in exchange for political favors if Menem won. ${ }^{8}$ The Group of the 15 did not hide its preference for privatization, private initiative, and repatriation of capital. They justified the new approach in the following terms: "the Argentinean worker is tired of protesting without any success and we believe that they might agree not to strike for ten years in exchange for good wages, affordable housing, and health care."

Menem won the elections, appealing to both the poor Argentine workers and the business community. ${ }^{10}$ once in power, though, his policies toward market-oriented reforms, alignment with the United states, and payment of external debt, marked the beginning of an era of a market oriented economy. One journalist viewed Menem's tactics as a "game

${ }^{7}$ The social pact has not worked in Argentina. Menem used other mechanism explained in the next paragraphs to implement the reform.

${ }^{8} \mathrm{Julio}$ Bazán, "Conflicto inmediato, o conflicto a mediano plazo," Redacción, April 1989, 67.

${ }^{9}$ Ibid.

${ }^{10}$ The reasons for Menem's victory is outside the scope of this thesis; however, it is possible to suggest that people voted for Menem to punish the Radical party (voto castigo) and gave the Peronists another chance. 
consisting of telling the people whatever the people wanted to hear, obtaining votes, then giving the country later what in reality the country needs. He had to give Argentines sweet candies to be able to give them medicine now."

III. DIVIDING AND CO-OPTING THE CGT AFTER THE ELECTIONS

Menem knew that he could not govern without union support for his economic plan. Consequently, after assuming office, and taking advantage of the economic chaos of the Alfonsin period, Menem concluded an agreement with the whole CGT and gained a two year strike-free pledge and wage freeze in support of a Peronist president. Immediately after, Menem tried to form a social pact among unions and business to liberalize the economy. However, the pact failed for lack of support from sectors of the CGT that began to realized Menem's real intention was to implement neoliberal reforms and abandon Peronism.

During the late Alfonsin period, two factions within the CGT began to emerge: the Ubaldinistas and the Group of 15 . Menem's presidential campaign strategy of negotiating with both sectors exacerbated the differences between the two. The Ubaldinistas were led by Saúl Ubaldini, secretary of the CGT. They opposed Alfonsin's economic stabilization policies and launched thirteen general strikes between 1983 and 1989 which paralyzed the whole country. Then, contrary to Ubaldini's tactics, the Group of 15 established a dialogue with the

"Juan Carlos Pérez, "Argentina: ¿de caballero a pordiosero?," The Miami Herald, July 1989. 
government and placed Carlos Alderete, a member of the Group of the 15, as Minister of Labor for Alfonsin. These differences became more profound when Menem continued to build a political coalition to support his economic reforms.

Menem started to build the coalition by organizing his cabinet "following a Peronist tradition to reflect in each ministry the main socio-political actors, he appointed a labor unionist as Minister of Labor, and a businessman as the Minister of Economy."12 He appointed Jorge Triaca, from the Group of the 15, to become Minister of Labor and a member of Bunge $y$ Born, a powerful business corporation to head the Ministry of Economics. ${ }^{13}$ The position as Minister of Labor has traditionally been a battleground for the most powerful unions of the CGT; SMATA, which is the Mechanics union, (Sindicato de Mecánicos Argentinos de Transporte Automotor), and the UOM, the Metalworkers Union (Union de obreros metalúrgicos), led by Lorenzo Miguel. By naming Jorge Triaca, Menem sent a signal to the CGT indicating his preferences for the Group of 15 instead of the traditional Peronist union sector. Jorge Triaca, leader of the plastic union, supported "the participation of the Group of 15 in the radical

${ }^{12}$ Ranis.

${ }^{13}$ Once in power, Menem said that "the state was going to be governed as an enterprise, like Perón said when he chose Miranda as Minister of Economics." Canitrot and sigal, "Interactions," 45. 
government," 14 against Ubaldini. Ubaldini did not want to accept Triacca as Minister of Labor and started a policy of direct confrontation towards Menem, opposing his policy of privatization and economic reforms. Immediately, Menem realized that if Ubaldini continued as General secretary of the CGT he would have problems implementing reforms. Menem then pursued an aggressive policy of dividing the CGT to diminish its power. Menem made the unions choose between him or Ubaldini, "indicating a sharp reversal of the 1983-89 tendency toward stronger ties between unions and parties."15 A pro-Menem sector within the CGT rallied under the slogan "the ones who brought Perón to power now follow Menem."16 While the Ubaldinistas refused to support neoliberal policies, arguing that they attacked workers salaries and benefits, the Menemistas argued that "the CGT, a traditional symbol of the Peronist party, cannot continue to oppose a Peronist administration like Menem's, and must instead insert itself in the President's political project." 17

The climax in the battle of Menem and Ubaldini came in September 1989, when the CGT Congress gathered to elect a new General secretary. Two candidates ran for the secretary

\section{8.}

${ }^{14}$ Acuña, "Política y economía en la Argentina de los 90," ${ }^{15}$ McGuire, "Political Parties," 45.

${ }^{16}$ Fernando Laborda, "Vuelven los jóvenes brillantes," La Nación, 16 April 1993.

${ }^{17 " D i v i d i d o ~ c o n g r e s o ~ d e ~ l a ~ C G T, " ~ M i a m i ~ H e r a l d, ~} 1989$. 
general position: Ubaldini, up to then leader of the CGT, and Guerino Andreoni, leader of the Commercial Worker's Union, pro-Menem. The Menemista faction won the elections with 719 votes against 644 votes, and 92 abstentions. ${ }^{18}$ Ubaldini questioned the legitimacy of the elections and "impugned the election because of 'procedural' irregularities."19 After refusing to accept the results, he abandoned the CGT Congress, causing the CGT to split into the CGT-Azopardo, supporting Ubaldini, and the CGT-San Martín, which was pro-Menem. ${ }^{20}$

Although both factions proclaimed to be the only CGT, on October 10, 1991, Menem declared that the only legitimate CGT was the CGT-San Martin. Henceforth, he stopped negotiating with the CGT-Azopardo. Moreover, the CGT-Azopardo was declared illegal. ${ }^{21}$ Later, in an obvious attempt to further divide the CGT, he supported the February 1992 initiative to reform the Law of Professionals Association. This reform annulled the article establishing that only one union per sector could be represented in the CGT. The reform called for

\footnotetext{
${ }^{18}$ Ibid.

${ }^{19}$ Ibid.
}

20The names "San Martín" and "Azopardo" refers to the streets where the headquarters were located. Acuña, "Politica y economia en la Argentina de los 90," 10. Teachers and state employees supported the Ubaldini faction while textile, automobile, light and power, telephone, and bank employees supported Ándreoni. The strong metalworkers unions, headed by Lorenzo Miguel, maintained good relations to both sectors. Ranis, Argentine Workers, 215. 10.

${ }^{21}$ Acuña, "Politica y economía en la Argentina de los 90," 
workers to have the freedom to choose whether or not to belong to the unions, and allowed more than one union per sector. ${ }^{22}$ Even though the division of the CGT caused the unions to lose strength, it did not end union-led opposition. Moreover, Menem did not relent. He resorted to other mechanisms to debilitate the structure of the CGT. He dismantled the welfare legislation in exchange for assuming the debt of the unions, elected unionists to the congress, and passed by decree a law restricting the right to strike.

IV. IMPLEMENTING THE NEOLIBERAL REFORMS-BUILDING THE POLITICAL COALITION

The division of the CGT and the appointment of Jorge Triaca as the Minister of Labor strengthened the government's power vis a vis weakened labor sectors. At this moment, the government proceeded to build the political coalition needed to implement reforms. As seen, neoliberal reforms bring opposition. To neutralize this opposition the government needed to build "ruling or sustaining coalitions" to carry on the economic and political reforms. Menem's first two years of government encountered distrust and opposition not only from labor but from some business sectors, the military, the church, and political parties, including his own political party. To control these sectors, Menem displayed a strong

${ }^{22}$ "Negativa reacción sindical ante los proyectos laborales," La Nación, 15 febrero 1992. 
capacity to craft alliances with key sectors of society. ${ }^{23}$ Normally, business would support economic reforms; but the strongest business corporations in Argentina grew under the populist regimes and were not prone to support free market competition. Bunge $y$ Born, Pérez Companc, and Amelita Fortabat's cement company are among some of the largest companies that benefitted from monopolistic practices. Some companies gained money "overcharging the state" to make their prices more competitive in the international arena. ${ }^{24}$ These sectors were used to making huge profits, being protected by the state, and when benefits were not as good, they were among the first sectors to run to the military barricades to ask for a military coup. ${ }^{25}$ Menem understood this reality and aligned with these sectors.

These alliances came through isolating the more orthodox sectors of his own party, and sectors from the left, and creating a new Peronism with the more progressive sectors of the party and the right, represented by the conservative party

${ }^{23}$ Even though this thesis deals mainly with labor opposition, a brief discussion of the neutralization of the other sectors is provided. For more on Menem and other societal actors see: Acuña, "Politica $y$ economía en la Argentina de los 90." Canitrot and Sigal, "Interactions." Smith, "State, Market, and Neoliberalism."

${ }^{24}$ These companies sold different goods to the state charging more than the fair market value. From this overcharging the companies were able to sell their goods in the international market at competitive prices. Acuña, "Politica y economía de la Argentina de los 90," 21.

${ }^{25}$ For example in 1976 when the government of Isabel Perón was overthrown, civilians cheered the military coup. Vacs, "Authoritarian Breakdown," 39. 
of Alvaro Alsogaray. Part of this right is the military. Menem has also dealt with them. While Alfonsin ordered investigations into the crimes committed under the military dictatorship and sent the members of the military participating in the coup to jail, Menem granted pardons, and came to terms with the military hierarchy. Pacting with the burgesois and the military makes sense in a country such as Argentina with a strong tradition of democratic instability due to these sectors. ${ }^{26}$

Through these alliances with the conservative right he tried to pact with the Congress. Although he had a majority in Congress, he faced resistance from the opposition parties and from his own party. Every time Menem could not gain Congressional support for his proposed reforms, he resorted to decrees (more than two hundred since 1989) or to distribute patronage among the allies. Minister Cavallo, for example encountered strong Peronism opposition in Congress when he wanted to start his economic reforms. Cavallo ignored the opposition, left Congress and suggested Menem to implement the package by decree. Before leaving cavallo said to the opposition: "If you don't like the economic reforms tell

\footnotetext{
${ }^{26}$ Around these big companies an economic sector grew at expense of the state and speculative behavior. These groups, called the patria financiera are the groups who became even richer with the neoliberal policies without investing in the country but through moving money according to internal and international interest rates (plata dulce).
} 
Carlos [Menem] to appoint another minister."27 Menem exercised a strong capacity to govern, "concentrating power at the executive level."28

To pass the laws to make the labor market more flexible, the government crafted alliances with the pro-Menemista sector of the CGT. ${ }^{29}$ Union support to labor law reform was given in exchange for the government assuming the $\$ 400 \mathrm{milli}$ ion debt unions contracted to provide medical services to its members under the prior military dictatorship. The government established a "clearing plan" (plan de saneamiento) with the National Administration of Health Insurance (ANSSAL) to liquidate the union's debt in exchange for an administrative rationalization plan calling for a drastic reduction in its personnel and congressional support for the reforms.

Traditionally, the CGT controlled the social security funds, but by assuming the debt, the government removed control from union management, allowing for unions members to choose their health care. Thus, although the CGT gained a short term financial windfall, it lost a traditional source of 22 .

${ }^{27}$ Acuña, "Politica y economía de la Argentina de los 90,"

${ }^{28}$ Gamarra, "Crafting Political support."

${ }^{29} \mathrm{As}$ in Eduardo Gamarra's analysis of the case of the COB in Bolivia, if approval can not be obtained in congress, or if alliances fail, then the neoliberal democracies resort (and I may add abuse) to extraordinary powers such as passing laws by decree, launching states of siege, or banning labor union membership. For more on the crafting of alliances and the use of extraordinary power see Gamarra, "crafting Political support." 
economic power. However, the government offered access to credit and a fair distribution of the social security funds to union's supporting governmental reforms.

During the state representative and governor elections in 1991, Menem offered positions to union members in exchange for political support. As Canitrot and sigal noted: "the labor unionists occupy positions in almost every sector of government." 30 For every pro Menem representative in the CGT structure, there is a congressional representative called "dipusindicales" (meaning half representative half union leader). Also, with Ubaldini's loss in the race for governor of the province of Buenos Aires, the CGT-Azopardo lost total power. Ubaldini's later resignation forced Lorenzo Miguel to establish a dialogue with CGT under the Menemistas leadership. The structure of the CGT was then modified to allow for five general secretaries from the most powerful unions to take turns in running the confederation in six months terms.

Menem was more successful than Alfonsin in his attempts to control labor opposition. The difference with the Alfonsin attempt to control labor lay in the fact that "Alfonsin wanted to affect reform with the intact structure of the CGT while Menem traded worker wages, working conditions, and labor legislation for access to government positions and control of union resources." 31 In a society such as Argentina where

\footnotetext{
${ }^{30}$ Canitrot and Sigal, "Interactions."

${ }^{31}$ Ibid.
} 
economic resources are scarce, patronage becomes an important tool.

V. PERMANENT CRIPPLING OF THE CGT BY CONTROLLING AND BANNING STRIKES

Peter Ranis suggests that "the majority CGT faction's conciliation with Menemism was made evident by the fact that, through mid-1991, not a single general strike was launched against the Peronist government." 32 However, the lack of general strikes during this period meant neither lack of opposition nor lack of sectoral strikes against the government. Union discontentment with the policy of tying wages to productivity and government handling of flexibilization of the labor market continues today, despite the loss of union power. In March 1990, even the official CGT "renewed its unconditional support to the President, but did not want to be linked to the President's economic plan." 33

When the privatization process started in 1990 , telephone and electric company workers went on strike in an attempt to stop the privatization process. Menem responded quickly: he declared the telephone strike illegal and fired 20,000 strikers. President Menem said: "they can call a thousand, a million strikes, but there will be no changes in the path we have chosen. If they want to strike I will not stop them. "34 When other workers, such as bus drivers, teachers,

\footnotetext{
${ }^{32}$ Ranis, Argentine Workers.

${ }^{33}$ clarin.

${ }^{34}$ Ibid.
} 
hospital employees, and auto workers threatened to join them, Menem responded with a decree regulating the right to strike. Decree 2184/90 was signed in October 1990, prohibiting strikes when they affect key sectors of the economy. The cases in which a strike can be declared illegal are described in article one:

it will be considered an essential service all services in which partial or total interruption can jeopardize the life, health, freedom, or security of part of the population; or any person in particular such as: (a) health services, specifically hospitals, (b) public transportation, (c) water, electricity, gas and other fuels, (d) telecommunications, (e) elementary and higher education, (f) the administration of justice, ( $g$ ) and in general, all those services that could jeopardize the interruption of any services or activities that put at risk the life, health, freedom, or security of the entire community or part of the community, and the classification of the strike will be given by the Ministry of Labor and Social Security.

This article resembles the International Labor Organization's definition of services vital to the population and forbidden from strikes. However, by adding the term freedom as a qualifier for declaring a service vital, the government can declare illegal any strike. As Juan Alberto Palacios and Jesús R. Marengo point out, the ambiguity in the term "freedom" gives the government a "wide discretionary power." Once the strike is declared illegal, the government can intervene and fire, lay off, or take any other measure against the workers and the unions it deems necessary.

When Ubaldini attempted to launch a general strike to protest the measure, even the powerful 300,000 metalworker's union voted against it, in fear of the consequences. "The 
loss of so many potential strikers forced ubaldini to scale back his plans ... by saying the strike would be only a demonstration." The only support he received came from the state-workers and teachers.

An illustrative example of the governments's firm policy toward the unions involved the railroad workers in 1991. When the railroad union called a strike to oppose privatization, the government responded by declaring the strike illegal. After that, the government proceeded to fire several thousands employees, it intervened the union, and closed several railroads routes. In the end, the unions were merely fighting to get the fired employees back to work.

When the strike ended, the government forced more than 66,000 employees to accept a forced retirement, leaving only 26,000 employees in the railroad sector. Today $11,920 \mathrm{~km}$. of railroad are closed, waiting for potential buyers, $20,759 \mathrm{~km}$. are privatized; and only $800 \mathrm{~km}$ are open and waiting to be sold. This caused tremendous inconveniences to users, especially among the Federal capital workers, whose only transportation was the railroads.

\section{CONCLUSION}

There is a tension between the implementation of austerity measures and the necessity to implement coalitions to support them. During electoral times, candidates will hardly use words such "austerity," "wage reduction," and "labor control" in their speeches. To get to power, political candidates need to build an electoral coalition that will 
guarantee their victory. Menem formed this coalition and was successful. Once in power, though, Menem decided to form a political coalition to implement neoliberalism.

These reforms bring opposition that needs to be neutralized by the government. The basic problem becomes, as Malloy acknowledges, "finding a basis for an ongoing stable system of governance. "35 Menem found (at least until now) "the stable system" for Argentina. He aligned with the conservatives to implement the neoliberal reforms. Moreover, he resorted to democratic and not so democratic means (decrees, corruption) to craft the political alliances needed. By siding with the business sectors, Menem left labor out of the political decision making center. This generated strong labor opposition.

To implement neoliberal reforms, though, Menem knew that he needed some sectors of the labor union movement to support him. He also knew that as long as the structure of the CGT was controlled by sectors opposed to market-oriented reforms and pro-business policies, as it were had been, he could not pass any reforms. Moreover, Menem understood that he needed to dismantle the corporatist structure of the CGT if his reforms were to succeed. He sided with the Group of the 15 and totally ignored the Ubaldinista sector. By dividing the CGT, and removing social security money control from their hands, Menem debilitated the structure of the CGT. After the

${ }^{35}$ Malloy, "The Politics of Transition," 256. 
CGT was divided, he co-opted labor unionist and exchanged political favors for unions support.

However, discontent prevailed among some unions belonging to the CGT. Aware of this discontent and the possibility of strike escalation, Menem passed a decree restricting the right to strike. Government reaction to the railroad strike deterred future strikes, as unionist and workers feared the consequences of staying off the job. The CGT lost not only the strike as a tool to oppose business oriented policies, but also its economic resources. This does not mean, however, that the CGT disappeared from the Argentine political context. It does mean that the CGT lost a central role under neoliberal reforms. If the CGT does not adjust to the reality of neoliberalism its role as a key institution in the politics of the country run the risk of no longer being needed by the Argentine working class. ${ }^{36}$ As Acuña concludes: "the governmental strategy towards unions was one of the main pillars the government used to send a consistent and strong signal to the business sector to shed no doubt about the [pro-market] direction the government decided to take." 37

The next chapter will analyze the internal structure of the CGT and the answers provided by the unions to the new context of neoliberalism. Given the context described above, Menem left unions with only one choice: to fight for survival.

\footnotetext{
${ }^{36}$ This will be analyzed in detail in the next chapter.

${ }^{37}$ Acuña, "Politica y economía en la Argentina de los 90."
} 

CHAPTER FOUR. THE CGT AND ITS STRUGGLE FOR INSTITUTIONAL
SURVIVAL

El poder sindical, hasta ahora, venia de arriba y no de abajo, de la incorporación al establishment, por eso se diluyó. Resurgirá si se recupera el protagonismo en los conflictos cotidianos y reales de los trabajadores.

Victor De Gennaro, Congreso de Trabajadores

\section{INTRODUCTION}

Traditionally, the confederación General del Trabajo has been linked with the Peronist party, giving it a key role in Argentine society. Under Peronism, the CGT became highly political, with "virtually all union leaders of importance identiflying] themselves as Peronist;"' but, Menem's Peronism heralded a new era for the Peronist party and the CGT. Under Menem, Peronism moved toward the conservative right, pushing the CGT out of the political decision making center. The CGT not only lost economic and political power, but struggled for institutional survival.

This chapter attempts to explain the internal response of the CGT to the loss of economic and political power under neoliberalism. ${ }^{2}$ By examining the history of the CGT, its present composition, the role of labor union leadership in response to austerity measures, and the working class under

\footnotetext{
${ }^{1}$ Epstein, "Labor-state Conflict in the New Argentine Democracy: Parties, Union Factions, and Power Maximizing," in The New Argentine Democracy. The Search for a Successful Formula. ed. Edward Epstein (Westport: Praeger, 1992): 125.

${ }^{2}$ Davila calls these factors internal factors because they come from the internal structure of the union, as opposed to the external factors, over which unions have no control. Dávila, "Apuntes para repensar."
} 
the reforms, the objective of this chapter is to prove that union decline resulted from the implementation of neoliberal reforms.

\section{HISTORICAL BACKGROUND}

Labor movements antedated Perón, but Perón reorganized unions according to state interests, and included them in the state apparatus. ${ }^{3}$ Before Peronism, the syndicalists, Anarchists, and Socialists ${ }^{4}$ competed to create a national trade union in an effort to unite the growing labor movement.5 In 1930, competing factions united into the CGT, "Argentina's first national central union." By 1937, the newly created labor confederation encompassed 70 percent of the nation's unions.?

After one term as Minister of Labor and two consecutive terms as president, ${ }^{8}$ General perón dismantled the small labor

${ }^{3}$ Daniel James, "Resistance and Integration."

${ }^{4}$ These were foreign ideologies that were brought to Argentina through the massive European immigration of the last century. For more on the labor union structure prior to Perón see Samuel Bailey, Labor, Nationalism, and Politics.

${ }^{5}$ Labor unions appeared in the last century; however, the first confederation of labor (FORA) was estabilished in 1901. After that, the confederation suffered several mutations: FORA IX, FORA V, Fraternidad obrera, Union Sindical Argentina, Confederación obrera, and the CGT (Confederación General del Trabajo). Ibid.

${ }^{6}$ Latin American Labor Organizations, ed. Gerald Michael Greefield and Sheldon L. Maram. (New York: Greenwood Press, 1987), 4 .

${ }^{7}$ Ibid.

${ }^{8}$ Perón was president for two consecutive terms from 19461955 when he was overthrown by a military coup. 
unions, centralizing power in bureaucratized unions under the CGT. Perón used the labor structure to build a populist coalition to support his national industrialization program. "By trapping worker discontent before it exploded," Perón was able to neutralize the consequences of the Depression era. ${ }^{10}$

For the first time, Peronism denounced the privileges of the land owning oligarchy, and divided the country between those who were part of the nation (workers and burgesses) and those who were traitors to Argentine national interests (the landlords and their foreign allies). According to James, Peronism's success resulted from:

[Perón's] capacity to recast the whole issue of citizenship within a new social context. Citizenship was not defined any longer simply in terms of individual rights and relations within political society but was now redefined in terms of the economic and social realm of civil society. ${ }^{11}$

During his presidency, Perón restructured the organization of workers, making the CGT "the most important branch of the Peronist party."12 Perón gave the CGT "broad

'Spalding, organized Labor, 155.

${ }^{10}$ Argentina based its integration into the world economy by becoming an agricultural exporting country. With the Depression following WWI, world exports fell by 25 percent with a great mass liquidation of foreign investment. As spalding suggests "the depression underscored the vulnerability of export economies to the vagrancies of world capitalism and industrialization appeared to be the way to solve this." Ibid., 125.

"James, Resistance and Integration, 16.

${ }^{12}$ Latin American Labor, 6. 
powers to intervene in union affairs." 13 He ruled that strikes had to be approved by government and that every national labor contract had to have three parties: business, the national government, and a centralized and increasingly subordinate union bureaucracy, represented by the CGT. ${ }^{14}$

After Peronism, labor unionism along with the armed forces, "were, indeed the two fundamental poles around which Argentine society seemed to revolve."15 without perón, the labor movement became a battleground among labor unions to control the powerful labor structure. Divisions among unions to accommodate or resist military coups became the norm, as well as military attempts to control them. Labor unionism during this period could be best described by "matonaje", 'pistolerismo', corruption, fraud, collaboration with employers, and bargaining with the armed forces."16 Linda Chen illustrates this point:

The eighteen years between peronist regimes illustrate several points about labor and politics. First, since 1955 every regime, military or radical, had its fortune tied to its effectiveness in dealing with labor. Their failure as governors was due to their failure to contain the activities of an highly politicized labor movement. Second, labor had not discriminated between nominal democratic or military regimes. When it saw its economic wel1-being threatened, it reacted. Third, every regime had attempted to divide and conquer labor, which exacerbated differences among the labor elites. Fourth, while clear differences existed among labor leaders, the

\footnotetext{
${ }^{13}$ Ibid.

${ }^{14}$ Ibid.

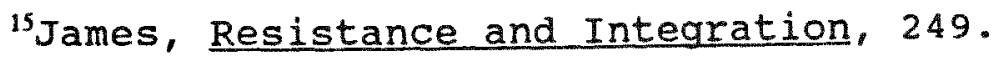

${ }^{16}$ Ibid. , 250.
} 
rank and file remained staunchly Peronist. ${ }^{17}$

For the last two decades, the labor movement has been in a process of political decline, which accelerated with President Menem. During the last military dictatorship, the CGT was abolished and hundreds of labor leaders were incarcerated or murdered. When democracy returned in 1983 , the CGT regained strength under Ubaldini, opposing the austerity measures of President Alfonsin, who was unable to build a coalition with the opposing forces. With the help of the Peronists in Congress, Ubaldini stopped every attempt from the administration to reform the corporatist structure of the CGT.

With Menem in power, the CGT envisioned a return to traditional Peronism, where labor was at the core of the political agenda. Instead, the economic core of the state became neoliberalism, which required the labor structure to be weakened further and the CGT to be neutralized. The policy of economic neoliberalism affected the structure of the CGT.

III. THE STRUCTURE OF THE CGT

The CGT is hierarchical, centralized, and represents 90 percent of Argentine unions. ${ }^{18}$ The CGT has 179 organizations and 2,500,000 members. ${ }^{19}$ Approximately 50 percent of the organizations are federations formed by smaller unions and 48

${ }^{17}$ Chen, "Labor Unions and Regime Transitions," 56.

${ }^{18}$ Trade Unions of the World 1989-1990, 2nd. edition (New York: Longman, 1989), 11.

${ }^{19}$ Ibid. 
percent are small unions, some with only 70-100 members. ${ }^{20}$ "It is estimated that 50 percent of the largest federations and unions make up two-thirds of the total rank and file."21

The council of the CGT (Consejo directivo) is divided into eight departments, (the Department of Unions and Interior, the Department of Inter-sectors Relations, the Department of International Relations, the Department of Legislation, the Department of Social Action, the Department of the Press, the Department of Political Relations and the Department of Accounting). ${ }^{22}$ Each department is managed by a secretary who is usually a member of one of the most powerful unions. Thus, most of the decisions of the secretaries have union guidance.

The CGT is directed by the General secretary. The General secretary is elected through internal elections. To unite the CGT after Menem's policies divided it, the leading unions compromised and allowed five General Secretaries, each having a six month term. As of August 1993, the General Secretaries were: oscar Lascano, from the Light and Power Union, José Rodriguez, from the Mechanics Union, Naldo Brunel1i, from the Metalworkers Union, José Pedraza, Pro Menem, from the Train Workers Union, and Ramón Baldassini,

${ }^{20}$ Ibid.

${ }^{21}$ Ranis, Argentine workers, 51.

${ }^{22}$ Consejo Directivo de la Confederación General del Trabajo de la Republica Argentina (Buenos Aires: CGT Press, 1993). 
from the Telecommunications Unions. ${ }^{23}$

CGT delegates vote on union decisions, but the leadership of the CGT has always been in the hands of the most powerful unions. Through membership and linkages with sectors that hold political power, union power increased. Unions between 2,000-10,000 members have one delegate in the CGT; those with 10,000-40,000 have two delegates, and those with more than 40,000 have three delegates. Unions with less than 2,000 members have no delegates. Some union leaders have demanded more autonomy, but "the centralized structure has been maintained to build stronger opposition under authoritarianism and to avoid excessive political dispersion under democracy."24 The peculiar structure of the CGT and greedy union leaders "contributed to [the CGT's] almost constant factional divisions." 25 Menem took advantage of this division and made decentralization a priority to dismantle the corporatist structure.

Although the CGT had great power with Perón, the labor movement was always dependent on the state apparatus. In 1945, Perón signed decree 23.852, known as the Law of Professional Association, which regulated "the unions" role in

${ }^{23}$ Ibid.

${ }^{24} \mathrm{Jul}$ io Godio, Héctor Palomino, and Achim Wachendorfer, El movimiento sindical Argentino 1880-1987 (Buenos Aires: Punto Sur, 1988), 84 .

${ }^{25}$ Trade Unions, 13. 
socioeconomic matters." 26 Unionization was based on "the unit of economic activity, rather than the individual trade or enterprise. In each area of economic activity, only one union was granted legal recognition to bargain with employers in that sector." 27 The collective bargaining process was based on free negotiation among unions and workers, but the state intervened to veto the existence of such negotiations if needed. ${ }^{28}$

The LPA regulates the labor structure today. ${ }^{29}$ Its major provisions are:

(1) Argentine's right of free association, ; (2) the right of the unions to serve as representatives of the working class; (3) the basic provision of one union per industry; (4) the notion, though not originally spelied out, that employers must pay union delegates and shop committees while they are pursuing union matters during the workday; and (5) the guarantee that union delegates cannot be fired during their elective term. ${ }^{30}$

Some of the more controversial issues relate to "the number and tenure of union delegates, the right to support specific political parties and become involved with political issues, [and the] employers' obligation to collect union dues

${ }^{26}$ Ranis, Argentine Workers, 44.

${ }^{27}$ James, Resistance and Integration, 10.

${ }^{28}$ Godio et al, El movimiento sindical, 41 .

29 "The law has been modified in four occasions, but it has not been significant altered in several of its major provisions." The law was modified under the Frondizi administration in 1958, the Peronist government of 1973, the military of 1979 and Alfonsin in 1988. Menem is attempting to modify it again. Ranis, Argentine Workers, 45.

${ }^{30}$ Ibid. 
in addition to contributing themselves to workers's retirement." While President Alfonsin restored several of these rights, which were abolished under the military dictatorship, Menem attempted to reform the structure of the unions to ultimately decentralize the labor movement. Menem's government removed social security funds from union control and tied wages to productivity, which does not allow for unions to negotiate wage increases. Finally, Menem attempted to modify the union hierarchical structure of the unions, which would have allowed for more than one union per sector, altering the centralized nature of the CGT structure. ${ }^{32}$

IV. THE STRUCTURE OF WORKING CLASS-EVOLUTION AND THE CHARACTERISTICS OF THE FORMAL AND INFORMAL SECTORS ${ }^{33}$

Until the 1930s, Argentina's economy was based on an agricultural export-led growth model; but the Great Depression uncovered the vulnerability of this model. To break away from

${ }^{31}$ Ibid. , 47.
${ }^{32}$ Ibid. , 49.

${ }^{33}$ In this section I will attempt to describe some general characteristics of the structure of the Argentine working class that might be related to the decline of the CGT. Arriving to definitive conclusion is very difficult because of the lack of studies done on the sectors. Palomino, one of the few social historians who attempted to analyze the social structure of the Argentine working class states: "Any attempt to answer questions about this issues encounters several problems, such as lack of data, deficiencies to find reliable data, and some theories that attempt to explain the change in the working class composition without any serious basis. The lack of information in reference to the social changes produced in Argentina is one of most difficult barriers encounter by any researcher. This forces theorist to infer sociological changes from the labor market and changes occurred in the occupational structure based on non reliable and incomplete data." Palomino, Cambios ocupacionales, 11. 
an economy dependent on an unstable international market, Argentina (and other Latin American countries) adopted "import substitution industrialization (ISI)."34 perón built the political support to carry ISI around a newly growing urban working class. 35

Between 1935 and 1946 industrial workers grew from 400,000 to 900,000 while union affiliation grew form 600,000 to three million. ${ }^{36} \mathrm{This}$ expansion of industrial workers continued until the 1970s. At the end of the 1970s, though, a severe process of de-industrialization affected Argentina's traditional working class composition. Godio et al. divide the evolution of the working class into three periods:

the first one, that lasts until the 1950s, in which industry absorbs a majority of the urban working class; a second one, which goes from the 1960 s to the 1970s, shows a change in the industrial sector, with a concentration in more sophisticated and technological advanced industries, with some signals of an increase in the tertiary sector (services, commerce, finance) and the period that starts in the 1975, in which industry starts declining, as well as the participation of the wage share in gross domestic product. ${ }^{37}$

Traditionally, the Argentine urban labor structure was characterized by "the relative scarcity of unskilled labor,...moderate unemployment and underemployment indexes,... [and] greater [wage] bargaining power stemming from

\footnotetext{
${ }^{34}$ Cardoso, Latin America's Economy, 6-12.

${ }^{35}$ Ibid. , 206.

${ }^{36}$ Godio et al. , El movimiento sindical.

${ }^{37}$ Ibid. , 66.
} 
the excess labor demand."38 The process of "poor macroeconomic performance observed in the 1980s" brought a growth in underemployment, strong wage retraction, a large degree of "hidden unemployment," and "deteriorating labor conditions." 39 The deterioration of labor market conditions help to explain the drop in personal income over the last ten years, since "changes in the labor market are related to a more regressive distribution of income which downgraded a large number oh households to poverty level. Without losing sight of the existence of other factors helping to explain the poverty phenomenon, evidence shows that the labor market plays a key role in illustrating the social situation in Argentina. " 40

The labor market is formed by the economically active population (EAP). The EAP "measures the visible supply of men and women able to work in the active economic system." 41 In this century, the EAP peaked at 40 percent in 1940 (with a population of $15,000,000$ people), while in 1989 the EAP was 38 percent (with a population of $31,928,519$ people). 42 The EAP

${ }^{38}$ Silvia Montoya, "Precarious Employment," Fundación Mediterránea Newsletter (Córdoba: Fundación Mediterránea, 1993), 4 .

${ }^{39}$ Ibid. , 5.

${ }^{40}$ Ibid.

${ }^{4 i}$ Palomino, Cambios ocupacionales, 12 .

${ }^{42}$ Statistical Abstract of Latin America, ed. James $W$. Wilkie, v.29, part 1. 
includes those who are employed and those who are unemployed. ${ }^{43}$ The employed category includes: wage earners, either from the private or public sector, owners who employ wage earners, and self employed workers. Among the unemployed, there is the group actively seeking employment, called visible unemployment, and those who are underemployed, working less that thirty five hours a week and seeking more hours, called visible underemployment. ${ }^{44}$ The only sector that belongs to unions are the wage earners, or workers from the formal sector, a sector that has been declining since the last decade.

Changes in the working composition produces changes in union composition. Traditionally, industrial workers were the backbone of the CGT structure. Labor demands, such as salary and working conditions were based on the needs of the industrial sector. "In the last two decades, [however] activities related to intermediation and social and personal services expanded while activities related to the production of good and services decreased." 45 consequently, the types of labor demands diversified as well as the composition of the CGT. The following table shows the changes in union composition, which reflects the process of de-

${ }^{43}$ Extreme care should be used when analyzing the EAP, since a growth in this number does not necessarily mean an improvement in the economy.

${ }^{44}$ Silvia Montoya, "Precarious Employment," 6.

${ }^{45}$ Palomino, cambios ocupacionales, 47 . 
industrialization starting in the last decade: ${ }^{46}$

TABLE ONE ${ }^{47}$

DISTRIBUTION OF UNION AFFILIATION BY ECONOMIC ACTIVITY EVOLUTION FROM 1936-1984

$\begin{array}{lrrrr}\text { SECTORS \& } & 1936 & 1945 & 1965 & 1984-1986 \\ \text { Industry } & 12 & 36 & 38 & 31 \\ \text { Transportation } & 41 & 31 & 17 & 10 \\ \text { Commerce } & 20 & 10 & 13 & 15 \\ \text { Services } & 17 & 17 & 28 & 36 \\ \text { Construction } & 9 & 4 & 1 & 6 \\ \text { Agricultural } & 1 & 2 & 3 & 2\end{array}$

Along with the process of de-industrialization a new phenomenon has become visible: the growth of the informal sector. The following statistics compiled by the International Labor organization (ILO) shows that since the 1970s the formal sector has diminished while the informal sector increased. ${ }^{48}$

TABLE TWO

EAP BY ACTIVITY \&

FORMAL INFORMAL TOTAL

$\begin{array}{llll}1950 & 56.8 & 15.2 & 72\end{array}$

$\begin{array}{llll}1970 & 66.0 & 15.6 & 81.6\end{array}$

$\begin{array}{llll}1980 & 65.0 & 19.4 & 84.4\end{array}$

The informal sector includes heterogeneous mass of "self employed workers; sporadic and seasonal workers; workers in

${ }^{46}$ Godio et al., El movimiento sindical, 72 . This tendency continues today.

${ }^{47}$ The logic for choosing these years is to show data before Perón, during his government, after Perón and before Menem assumed office.

${ }^{48}$ Statistical Abstract, table 1316. 
small, including family, enterprises; undocumented workers, workers in unregistered businesses, underemployed workers; housemaids, artisans and laid-off factory workers performing odd jobs." 49

While neoliberal economists argue that the growth of the informal sector provides the necessary cushion for neoliberalism to work, critics of neoliberalism argue that the informal sector is a disguised name to call the unemployed. ${ }^{50}$ Regardless of either argument, the growth of this sector undermines labor union representation. ${ }^{51}$ As Conaghan et al. acknowledge "the growing marginality of the traditional working class undercuts the power of the trade unions and their anti-neoliberal mobilizations. When the informal sector of the economy sector expands, trade unions are left with a stagnant or shrinking constituency-a fact taken into account by the neoliberal teams." 52

The CGT only protects workers belonging to the formal sector. As the informal sector grows, unions lose members and revenues, since only workers in the formal sector contribute unions dues. Growth of informality, "carrie[s] the

${ }^{49}$ Córdova, "The Informal challenge."

${ }^{50}$ Zapata, "Towards a Latin American Sociology," 395.

${ }^{51}$ It is not the intention of this researcher to prove if workers are better off or not under neoliberalism or if the growth of the informal sector is or not good for the growth of the economy, but to show that the growth of this sector negatively affects unions composition.

${ }^{52}$ Conaghan et a1., "Business and the Boys," 25. 
implication of a lack of protection to the worker due to the loss of his social payment rights (pensions, health care, severance pay, etc.) and greater job instability."133

Some verified phenomena illustrate the growth of the informal sector as follows:

(1) The legal age to work in Argentina is fourteen, but a recent report published by the ILO shows that up to 200,000 minors, (a figure that is increasing) between the ages of four and fourteen work illegally in agriculture, industry, and business. Labor officials acknowledge the problem, but they say it is difficult to track. CGT representatives say that they only take care of unionized workers, noting that children work under the informal sector. ${ }^{54}$

(2) The self employed sector has grown dramatically in the last decade. For instance, while in "the 1980s the self employed sector was an alternative to de-industrialization in the 1990s it was the alternative to an increasing number of lay off state employees left out of the neoliberal model." 55 Lay off workers searching for a job are part of this growing sector. Some statistics show this growth. While in 1947 , only 355,000 people were self employed, in 1980 it reached $1,620,000$ people, and in 1993, 2,500,000 people. Approximately one third of the 2,500,000 work in business, one

${ }^{53}$ Silvia Montoya, "Precarious Employment," 5. 54"Chicos Explotados," Clarín, 6 July 1992, 6.

ss Sandra Román, "El cuentapropismo contra las cuerdas," Clarín 3 October 1993, 26-7. 
third are professionals, and the reminder work in real state, construction, transportation and various other industries. ${ }^{56}$ This sector grows at the expense of the formal sector and obviously is not unionized.

(3) Privatization contributed to the growth of the informal sector. In a 1993 poll among the twenty seven largest Argentine companies, 78 percent responded that they had to lay off personnel when they bought state owned enterprises, 15 percent said that they kept the same personnel, and only 7 percent responded that they had increased personnel.57 Moreover, since 1991, 66,000 railroad workers were forced into voluntary retirement. This affected the railroad union that used to have 167,908 members in 1973, and today has less than 76,000 members. The privatization of the government-owned winery Giol is another example. Originally, the firm had 3,548 employees; after privatizing only 167 employees remained. "The downsizing was carried out through a combination of incentives, including early retirement, voluntary resignation, job replacement guarantees, indemnization, and layoffs based on legal, social, financial, and economic criteria." 58 Unions were powerless thorough this process.

${ }^{56}$ Ibid.

${ }^{57}$ Christian Association of Business, Noticiero Informativo, July 1993.

${ }^{58}$ Marla de la Esperanza Juri, "Argentina: Privatization of a Government-Owned Winery," Economic Reform Today (Winter 1992): 7 . 
Rising unemployment has also affected union membership. While urban unemployment was 3.7 percent in 1975 , in 1987 it was 5.9 percent, in 1990 it was 8.65 percent, and in May 1993 it reached 9.9 percent of the EAP $(1,100,000$ unemployed people). Official statistics show that currently 18.7 percent of the EAP is either unemployed or underemployed; this is more than 2,200,00 people suffering employment-related problems. Also, there is a large constituency within the employed (empleo oculto) who are illegally hired without benefits, who escape the realm of unions.

The growth of the socially unprotected informal sector and unemployed affect union affiliation and their capacity to negotiate politically. ${ }^{59}$ Unions have experienced a decline in membership, which decreased revenues and their economic base. For example, traditionally strong unions, such as the Constructions workers (UOCRA) and the Mechanics Workers (SMATA) have been reduced to 100,000 members and 89,000 members respectively from 260,000 members and 121,135 members respectively in $1973 .{ }^{60}$ The inability to protect workers from the wage restriction policies, unemployment, and welfare legislation affected not only membership but the credibility of the unions among the workers.

V. LEADERSHIP, INTERNAL COMPETITIONS AMONG FACTIONS WITHIN THE CGT, AND UNION CREDIBILITY

${ }^{59}$ Espinal, "The Right and the New Right," 3 .

${ }^{60}$ Ricardo Rícs, "La decadencia del poder sindical," Clarín 6 October 1991,6 . 
In CGT. E1 poder que no fue, ${ }^{61}$ (CGT. The Power That

Never Was) Grande suggests some interesting questions: Does the CGT have any power in the present context of neoliberalism? How do union leaders view themselves in the process of economic transformation? Are unions still the mediators between government and the workers? Why do unions compete for control more than to protect the workers?

Union leaders admit that the structure of the labor organization is fading for different reasons. Aside from external reasons, lack of appeal to a changing working class are contributing to the unions to decline. Even though the different factions came to terms with uniting under the one legal CGT, three internal groups still exist: the Friends of Menem, the so called "elephants," and the group that is against Menem.

The Friends of Menem support Menem's economic policies. Its main leaders are Andrés Rodriguez, from the Union of state Employees (UPSP), Rubén Pereyra, from the Water Workers Union, and Pedro Goyeneche, from the Textile Union. Their slogan has been "the ones who brought Perón follow Menem." This group exchanged their support for Menem's reform for key political positions in PAMI and ANSSAL, which are institutions controlling the retirement structure and the social security and health services structure. Moreover, some unionists have

${ }^{61}$ María Herminia Grande, CGT. El poder que no fue, 1993. 
gained Congressional seats in the october 1993 elections. ${ }^{62}$

The second group, called "the elephants," formed alliances with government or attacked it depending on the circumstances. For example, Lorenzo Miguel from the UOM, called Menem a "traitor" and "regretted voting for him" publicly. On September 15, 1993, he invited President Menem to speak to the CGT in memory of Eva Perón. Miguel gave Menem a warm welcome on his first official visit to the CGT, gaining opposition from the third sector.

The third group is formed by unions totally opposed to Menem's neoliberal policies. Workers from these unions, such as teachers and public health employees, experienced severe cuts in wages and social benefits. ${ }^{63}$ some unions from this group are: The Teachers Union (CTERA), headed by Mary Sánchez, Alberto Piccini, from SMATA, and State workers headed by Víctor de Gennaro. ${ }^{64}$ They believe that only by offering an alternative union structure unions will unions be able to offer opposition to the government and aid the workers. This group is supported by members of the Small Business Association, the Federation of University students, dissidents Peronists such as Fernando Pino Solanas and Chacho Alvarez, and Humberto Volando, a leader from the agricultural sector.

${ }^{62}$ Among others, Naldo Brunelli, from the UOM, Patricia Bullrich and Roberto Digón. two sector.

${ }^{64}$ The state workers are divided into two opposing unions, one is pro-Menem and the other one is not. 
At times, these factions acted more for personal interests rather than worker interests. As unionist Armando Cavalieri said: "the CGT's division was a consequence of putting unionists interest over workers interest, without thinking that with the split the only ones who got hurt were the workers." 65 Traditionally, the most powerful unions have been the ones that controlled the structure of the CGT. Labor scholar Epstein suggests that "official favoritism" more than "leadership ideology" explains these divisions and how similar unions, such as the metalworkers and the auto-workers, for example, belong to different factions. ${ }^{66}$ Epstein sees labor unionists as "power maximizers, subject to pressure from workers on the shop floor and pressure from the members of the government. " 67

The divisions also helps to explain the lack of credibility among rank and file workers. On November 1992 , when the CGT announced its first general strike against Menem (that was never done because of intense negotiations with the government), 50.4 percent of the people polled in Buenos Aires were against the strike, 28 percent were in favor, and the rest either did not care or were unsure. Low percentages of support in Buenos Aires "evidence that a crisis of identity

${ }^{65}$ Grande, CGT. El poder que no fue, 133.

${ }^{66}$ Epstein, The New Argentine Democracy, 126.

${ }^{67}$ Ibid. , 125. 
has occurred without the CGT as reflecting Peronism ideology."68 The rank and file no longer trusted the CGT's good intentions. In the end, no general strike was attempted to oppose neoliberal policies during the first three years of Menem's Administration.

Corruption and accusations against ex-labor unionist Luis Barrionuevo exacerbated this distrust. The Minister of Labor Barrionuevo had to resign after publicly admitting that in Argentina "nobody becomes rich through decent work." Moreover, he has admitted to accepting bribes.

Does this mean that workers are content with neoliberal reforms? Not quite. A closer examination reveals that underground discontent increased during the first years of Menem's reforms. While "Peronist CGT leadership could stop general strikes from 1989 and 1990 as a means of politically aiding candidate and then president Carlos Menem, they had less success in controlling the escalating number of ordinary strikes taking place with the return to power of a peronist government." 69 The following statistics illustrates this point. From July to December 1988, there were 263 strikes against the Alfonsin administration, while Menem for July to December 1989 had 335 strikes. During the first six months of 1990, there were 401 strikes compared to 245 for the same period at the end of the Alfonsin Administration. With a

\footnotetext{
${ }^{68} \mathrm{La}$ Nación, 8 November $1992,6$.

${ }^{69}$ Epstein, The New Argentine Democracy.
} 
majority of the strikes taking place in public sectors, especially among teachers and health workers, "the strike limitation decree of the new government was an attempt to discourage such embarrassing work stoppages."70

Apart from privatization and layoffs, wage policies were among the worker demands, but a minor cause for the CGT. The CGT could not alter wage rates and had to accept the clause tying wages to productivity, reducing its opposition to filing a complaint with the International Labor organization (ILO). While in 1986, average real wages were 99.3 percent, with a purchasing power of 105.6 percent, in 1992, real wages declined to 68.3 percent and purchasing power was 76.2 percent. ${ }^{71}$ According to official statistics, 20 percent of the poorest sector of the population received 4.9 percent of the total GNP, while 20 percent of the richest sectors received more than 50 percent of the GNP. The previous year, the poorest 20 percent received 5.7 percent. During the first year of Menem's governance, supermarket vandalism and food riots in Córdoba and Buenos Aires continued as part of the population protests toward an economic policy detrimental to the lowest classes.

Wage decreases under neoliberalism were based on the premise that high labor costs hinder business competition in Argentina. Not only wages decreased but thousands of workers

${ }^{70}$ Ibid., 152.

${ }^{71}$ Daniel Muchnik, "La Pobreza creció $50 \%$ en America Latina," Clarín 4 October 1993, 50-1. Based on 1985=100. 
lost their jobs with the reforms. This translated into an increasing poor sector with a lower wealth distribution. ${ }^{72}$ Increasing levels of imports discouraged productivity in the basic industries and negatively influenced employment. It seems that the real problem is not high labor costs but lack of investment. The economy cannot provide work for the increasing number of unemployed.

On one hand, unions can no longer protect workers from unemployment and low wages policies, much less unions can protect the unemployed. As with the railroad worker's strike, the government did not change its policies, forcing unions to lower demands. Workers, on the other hand, are afraid of going on strike because of fear of losing their jobs. In a scarce labor market, the risk of not finding a new job is high. As Steve Levisky and Tony Lapps suggest "public sectors cuts will almost certainly undermine union strength. First and foremost, unions ranks will inevitably be depleted by the laying off of many unionized worker...moreover, threats by owners to shut down or move their businesses have dampened enthusiasm for strikes. As a result, unions that concentrate their efforts on the struggle for higher wages are appearing increasingly ineffective."

\footnotetext{
${ }^{72}$ This tendency is common to all. Latin America, in which statistics from the world Bank show that poverty is concentrated in the urban areas, with more than 50 percent of the population leave in extreme poverty. From 22 percent in the last decade, the amount of poor people increased to 32 percent more. The poorest 20 percent of the population receive four percent of the total wealth. Ibid.
} 
Workers have lost faith in their labor union leaders, and are looking for alternative structures for protection. Canitrot and Sigal suggest that increasing religious sects or grassroots organizations are a consequence of a decline in the labor unions. ${ }^{73}$ Whether the poorest sectors are looking at religious sects or other institutions is still not clear. More research needs to be done in this area. However, in the context of neoliberalism, the poor, the unemployed, and the workers in general no longer seem to have any organization to protect them from the negative effects of neoliberalism.

VI. CGT RESPONSES TO THE POLICIES OF NEOLIBERALISM

The implementation of neoliberalism changed social relations in general and the structure of the CGT in particular. Menem was able to neutralize the unions through a policy of fragmentation and dismantling the welfare legislation. He removed control of the social security funds from the unions and declared strikes illegal in exchange for political favoritism with loyal unionists.

After the chaotic period of initial austerity, Menem exchanged wage increases for stability with the workers. This exchange neutralized potential workers discontent. The October 1993 elections demonstrated that economic stability is important to the Argentine working class, who voted for Peronism. Gamarra's arguments for the Bolivian case could also be applied to Argentina: "The social costs

${ }^{73}$ Canitrot and Sigal, "Interactions." 
of..hyperinflation proved to be higher than those of stabilization measures, [thus], popular support for a continuation of [these] policies undermined any effort by the [unions]...to counter their imposition." 74 This important change in rank and file perception should be taken into account by the unions.

Since Menem became President, the CGT was not able to mount a general strike to protest wage decreases, increased unemployment, or decreasing social rights. The CGT has not been able to alter labor conditions either. At this point, the CGT is just struggling for institutional survival. Why did unions accept a marginal role under neoliberalism? Is it that they no longer represent societal and worker interests? Couldn't they oppose the measures in a firmer manner?

When Menem's administration began, the new CGT supported the economic reforms of the Peronist government. As Epstein suggests, Menem's Peronist affiliations forced leaders to give a Menem an opportunity to implement reforms. ${ }^{75}$ Menem's subsequent shift to neoliberalism split the CGT, weakening its unity. Unions who supported Menem received favors, while the opposition was isolated. Menem's ability to co-opt sectors of the CGT allowed him to implement reforms and further weaken union structure. Personal aspirations drove unionist behavior rather than the well-being of the working class.

${ }^{74}$ Gamarra, Market oriented Reforms, 68 .

${ }^{75}$ Epstein, The New Argentine Democracy, 154. 
CGT's protests against unfavorable labor policies were reduced to speeches and failed attempts to strike. As a consequence of Menem's division of the CGT, ${ }^{76}$ the union movement lacked unity to oppose the reforms. This undermined the rank and file's trust in the ability of the unions to protect them against policies of firing workers who strike. Unions protesting privatization encountered a strong government that laid-off strikers, declared strikes illegal and threatened disband the unions themselves. As Epstein suggests: "while they seem to use their ties to the Peronist government to ameliorate to the extent possible the effect of such economic change upon their own union members, they do not seriously question the government economic program and the social costs...Their loyalty to Peronist government [is] limited [though], contingent on their appraisal of that government's ability to be able to maintain itself in political power." 7

VII. CONCLUSION

The response of the CGT to neoliberalism represented a combination of an inability to act promptly to stop the implementation of the measures and a declination to act in favor of workers. Inability to oppose wage controls and the dismantling of the welfare legislation contributed to the decline of Argentine labor unions. Lack of internal unity or

\footnotetext{
${ }^{76} \mathrm{As}$ discussed in Chapter three.

7 Epstein, The New Argentine Democracy, 151.
} 
a plan to ameliorate the effects of the reforms on the rank and file produced a lack of confidence in union leadership. The external factors discussed in chapter three, such a the globalization of the economy, the economic background, and the implementation of the economic reforms, all contributed to diminish the CGT's power. With Menem, the CGT lacks the strong role it enjoyed under previous Peronist governments. Without the political or economical power to oppose neoliberalism, the CGT now struggles for institutional survival. The CGT needs to revise its role under neoliberalism to adapt to the changes in the composition of the working class. It must incorporate in its strategy not only the needs of workers from the formal sector, but the workers from the informal sector, since this sector is increasing at the expense of the formal sector. As wages are so low, perhaps workers are interested more in solving immediate problems, such as housing, food, or just keeping a job, rather than pushing for higher wages. In the october 1993 elections, Menem's party received more than 50 percent of the vote. Workers voted for stability, at the expense of wage increases.

If unions do not adjust to the changes of neoliberalism, they risk disappearing from society. If unions cannot negotiate wage increases, strike, oppose labor reforms, or provide basic services to its members the rank and file may feel union affiliation is unnecessary. In many cases, workers are maintaining their membership more as a tradition rather 
than because they support the union policies. ${ }^{78}$

${ }^{78} \mathrm{Grande}$ CGT. El Poder que no fue, 60. 
En el 83' aún pensábamos que teníamos el poder de los $70^{\circ}$. Ese error nos llevó, incluso, a perder las elecciones presidenciales. Desde el $83^{\prime}$ en adelante no corresponde que el sindicalismo hable de poder. Lo hemos reducido a un mero mecanismo de autodefensa.

Jose Pedraza, Unión Ferroviaria

\section{INTRODUCTION}

The 1980 s wave of neoliberal reforms and democratization changed the traditional political-economic arena of Latin American society. The "state center matrix" collapsed as new political arrangements emerged (Chapter one). Under the SMC, the state controlled the markets for goods and labor, civil society was expanded, labor organizations were strengthened, and several corporativist channels were created linking public organizations, political parties, and unions.' The labor movement was at the core of the SMC.

Under the neoliberal matrix, the state encouraged privatization of state-owned enterprises and business controlled the markets for goods and labor. Civil society, and labor unions in particular, declined under the dual processes of neoliberalism and democratization. The neoliberal project revolved around the market, displacing labor to the periphery. Argentina is representative of this political phenomenon.

The Argentine labor movement gained strength under the populist government of Perón. As discussed, the confederacion

1Cavarozzi, "Beyond Transitions," 14-23. 
General del Trabajo became the "most important branch of the peronist party," (Chapter four) and played an important role throughout Argentine history. However, when he assumed office in 1989, Menem adopted neoliberalism instead of traditional Peronism. In doing so, labor unions became the principal target of Menem's neoliberal restructuring effort.

Some scholars argued that governments could not ignore demands for redistribution when implementing orthodox reforms, especially "when trade unions [were] extremely organized and powerful."2 Contrary to this argument, Menem introduced reforms favoring business interests, which delayed the promised social distribution. Through labor control and political alliances, Menem was able to overcome opposition and successfully implement the reforms, demonstrating that a leaders's capacity to implement reforms had become an important variable to be considered when analyzing the process of neoliberalism. ${ }^{3}$

Menem's ability to control unions, manage the economy, and manipulate public opinion, sustained his neoliberal model. In theory, neoliberalism implies a policy of laissez faire, but Menem tied wages to productivity which strongly favored business. Moreover, Menem did not hesitate to bypass Congress, governing by decree when he could not pass a law

\footnotetext{
${ }^{2}$ Vacs, "Authoritarian Breakdown." Also John Sheahan, patterns of Development in Latin America: Poverty, Repression, and Economic strateqy. Princeton: Princeton University Press, 1987.

${ }^{3}$ Gamarra, Market oriented Reforms, 93.
} 
with congressional approval. A majority of the laws regulating labor control became law through executive decrees. As Conaghan et al. argued

with groups in civil society having been defined as the enemy, it was only natural that decision making would be structured as a highly exclusionary process...the costs implications of neoliberal stabilization called for executives capable of acting in a decidedly authoritarian mode, despite formal democratic frameworks within which executive power was formulated and legitimated. In short... we see the outlines of a hybrid form of government in which a formal democratic facade masks a real authoritarian bent, especially in the area of economic policy. ${ }^{4}$

Neoliberal reforms were implemented, but at a high cost, especially in the labor sector. To make prices more competitive, Menem cut labor costs and dismantled welfare legislation. As a result, wages declined, and social benefits, such as retirement plans and other worker protection laws, were restricted (Chapter three). Lower wages, privatization, forced layoffs, growing unemployment, and less welfare legislation brought labor opposition. The CGT, however, did not respond fast enough to the reforms. After three years under Menem's administration, the CGT's role has became defensive rather than aggressive. Under neoliberalism, the CGT lost political and economic power and is struggling for institutional survival.

This study aimed to unveil the processes by which the CGT lost strength in the context of democratization and economic reforms. Sonia Dávila's framework of analysis was used to

${ }^{4}$ Conaghan et a1., "Business and the Boys," 27. 
prove: (1) the decline of the CGT resulted from the implementation of Menem's neoliberal agenda of displacing labor and putting market at the core of his political project, and (2) the implementation of neoliberal reforms required both a weakened labor union organization and a government capable of controlling labor.

II. FRAMEWORK OF ANALYSIS

By looking at the Argentine CGT, this thesis attempted to answer the how's, why's, and what's of the contemporary phenomenon happening in Latin American: labor union decline under neoliberal reforms. Dávila's framework of analysis, that was used to study the Central obrera Boliviana, aided this study in three ways: (1) Bolivia's COB was also very strong under populist regimes, exhibiting some of the centralized CGT characteristics; (2) Bolivia also adopted neoliberal reforms, and (3) these reforms negatively affected labor and the labor movement structure.

This thesis followed Davila's framework of external and internal factors affecting the labor union movement. In reference to the term "external," Dávila meant external to the labor organization, or any factor "that comes from the actors" external actions and decisions, situated outside the realm of the labor movement that impacts unions." These were grouped into economic (Chapter two) and political factors (Chapter three). The CGT had no control over external factors.

5ávila, "Apuntes para repensar," 6 . 
By internal factors, Davila meant factors internal to the labor union structure and over which unions have control. According to Dávila, internal factors are "those factors that come from the internal actions and decisions of the labor movement, that affect the unions' collective action, its unity, and behavior as an entity." "The CGT had control over these factors (Chapter four).

After analyzing these factors, the conclusions of this thesis agree with Davila's: external factors led to union decline. Moreover, the successful (in the IMF's terms) implementation of neoliberal reforms in Argentina is one of the main factors exacerbating the CGT's decline. Menem's decision to implement neoliberalism occurred outside the realm of the CGT.

By definition, neoliberalism implies that labor demands will be postponed until growth begins because the reforms favor business over labor, at least in the short run.7 Consequently, to implement the reforms, Menem had to break the labor union structures through several mechanisms of control. Neoliberal reforms undermined labor's political and economic power. As seen, union affiliation diminished, especially in key sectors of the economy. This translated into less members and lower membership revenues. The

${ }^{6}$ Ibid. , 7.

${ }^{7}$ This does not imply that there is a confabulation to hurt the poor, but it is part of the belief that distribution will come later, after stabilization. It is also part of the famous discourse of trickle down economics. 
flexibilization of the labor market, as part of the neoliberal reforms, undermined the CGT's ability to organize collective pressures. In tight labor markets, the rank and file are less likely to support unions demands to strike, and the stabilization component of the reforms make workers less willing to challenge the model, fearing hyperinflation and instability. ${ }^{8}$

Menem's ability to coopt unions produced an irreconcilable split in the CGT. Menem eliminated the CGT's ability to strike and removed social security funds from union control. The control of these funds were then used to leverage support. Also, by tying wages to productivity, Menem shut the door for wage negotiations, leaving unions no possibility to challenge the reforms.

External factors were predominantly responsible for the CGT's decline. This does not mean that internal factors did not contribute to the process. Internal rivalries within the structure of the CGT aided the co-optive process. To become part of the central decision-making body, several unions accepted governmental propositions regardless of the position of less powerful unions. The CGT's inability to respond to neoliberalism contributed to rank and file distrust of union leaders. Some unionists recognized the urgent need to adopt a new strategy to appeal to the working class for union

${ }^{8}$ People accepted Menem's slogan, "stabilization first and growths later." Now, if growth does not come, will people continue to wait? 
survival. Being unable to demand wage increases or stop labor reforms, what use is the CGT?

III. ARGENTINA AND THE INTERNATIONAL CONTEXT

Similarities do exist between the Argentinean case and the process of labor union disintegration in Latin America and in western industrialized nations mainly because the process of neoliberal reform was a global phenomenon. Before the 1980s, liberalism and democracy were more the exception than the rule. After the 1980s, developed and developing nations combined market economies with 1 iberal democracies. ${ }^{9}$ It could be argued that the Latin American case represents a general trend of the Western hemisphere.

Taking neoliberalism as a given phenomenon and arguing that neoliberal reforms means placing the market at the core of the political agenda and labor at the periphery, it is likely that labor and the labor movement will suffer. Under the context of neoliberalism, labor unions are forced to adopt a marginal role to allow for market competitiveness. In the United states and Great Britain, distrust for unions and organized labor in general grew in response to a world-wide distrust in leftist political ideals and an exaltation of the benefits of extreme individualism.

The process of U.S. labor union decline dates back to the 1950 s and happened under a different context than in Latin America. To mention one dissimilarity, the state in the United

Vacs, "Convergence and Dissension," 13. 
States has not traditionally been part of the labor negotiations as in the Latin American. Labor unions, however, declined during the last decade, coincidentally with a worldwide trend. More comparative research should be done, though, to find parallels between Latin America and the United States. ${ }^{10}$

The "rise and decline" of labor unions is clearer, though, where a "neoliberal matrix" has replaced "populist matrix" in the context of democratization, such as in many Latin American countries." A parallel could be drawn between Argentina and Bolivia, Uruguay, and Peru, for example. In these three countries, strong labor confederations lost power under neoliberal reforms. The informal sector grew as government used successful tactics to neutralize labor opposition. ${ }^{12}$ More comparative studies need to be done at the micro level to analyze the historical and political context surrounding these confederations. Have all governments used the same methods of labor control as Menem? How did factions arise? Have unions declined during the same period of time they did in Argentina? The framework used in this thesis may

${ }^{10} \mathrm{Jack}$ Fiorito and Cheryl Maranto review six of the most prevalent explanations for the contemporary decline in the United states in their article "The contemporary Decline of Union Strength." Contemporary Policy Issues, v.5, n.4, $(1987): 12-27$.

"Although the transition toward democracy and markets in Latin America antedated the collapse of the Soviet Unions, it certainly was affected by the global changes towards neoliberalism. Gamarra, Market oriented Reforms, 91.

${ }^{12}$ Conaghan et al., "Business and the Boys," 25. 
advance research in that direction.

IV. POSSIBLE SCENARIOS AND FINAL THOUGHTS

The future of Argentina's labor unions, as with those of other Latin American countries, is unpredictable, but there are explorable scenarios based on present conditions. one possibility is that the neoliberal reforms will continue, either because Menem amends the constitution and is reelected or because future administrators continue with the reforms. In such case, the CGT is likely to continue losing power. Unless the CGT restructures its corporatist structure and reexamines its role in society, no major changes are likely.

Under the most optimistic alternative, the CGT will administer to the needs of Argentina's workers, and provide services to workers in the formal and the informal sectors. In this scenario, unions will focus on providing basic services to its members instead of political posturing. This alternative, though, will not help unions regain power.

Labor unions lost political and economic power, and unless a new populist regime comes to power, labor unions will continue losing strength under neoliberal reforms. This leads to the third scenario. Nothing guarantees that this period of neoliberalism is not another cycle in the many cycles of populism and antipopulism regimes in Latin America. ${ }^{13}$ It is open to speculation if labor unions can recover a central role in the case of a new cycle of populist regime arrival.

\footnotetext{
${ }^{13}$ Conaghan, Malloy, Gamarra.
} 
Whether or not unions regain power, the irony of democratization and neoliberalism is that the working class and the poor are likely to continue to experience poor economic conditions. With the loss of unions advocates and no emerging working class advocates on the horizon, it is time for workers to raise the social consciousness of the citizenry with the aim of increasing participation in worker organizations and ultimately changing the corporatist labor movement structure. At the same time, the decline of the working class and labor unions under neoliberalism brings up a more interesting debate. Is neoliberalism compatible with democratization?

Menem's use of an authoritative style to create reforms that excluded the working class stretched the limits of democracy. Menem is still considered a democratic leader, but a leader that resorts to any means to achieve the consensus for neoliberal reforms to work. These mechanisms seem to be working effectively,... at least in the short run. This debate leads to the importance of governance and the context in which the reforms were implemented. context is another important variable to be considered when analyzing any aspect of the reforms.

It is premature to conclude whether Menem will continue to generate the support necessary to implement the reforms. Presently it looks like he will be able to reform the constitution allowing for his reelection through very interesting political arrangements with his opposition. After 
that, his success will depend on the long term results of neoliberalism, the political context of the time, and his ability to continue crafting alliances to sustain his reforms. 
Acolla, Peter. "Privatization in Latin America." In Foreign Labor Trends. Washington DC: US Department of Labor,

Acuña, Carlos. "Politica y economía en la Argentina de los 90 (0, por qué el futuro ya no es lo que solía ser)." Paper presented at the Conference on "Democracy, Markets, and Structural Reforms in Latin America," "Buenos Aires,
March 1992.

Alexander, Robert. organized Labor in Latin America. New York: Free Press, 1965. Juan Domingo Perón: A History. Boulder: Westview
Press, 1979.

\section{Argentine Business News}

Ascher, william. Scheming for the poor. The politics of Redistribution in Latin America. Cambridge, Mass: Harvard University Press, 1984.

Bailey, Samuel. Argentina. 1977.

Labor, Nationalism, and politics in New Brunswick: Rutgers University Press,

Beliz, Gustavo. CGT, el otro poder. Buenos Aires: Planeta, 1988.

- Menem. Argentina hacia el año 2000. Buenos Aires: Editorial Galerna, 1986.

Bergquist, Charles. Labor in Latin America: Comparative Essays on Chile, Arqentina, Venezuela, and Columbia. stanford: Stanford University Press, 1986.

Borón, Atilio. "Becoming Democrats? Some skeptical Considerations on the Right in Latin America." Paper presented at the IPSA XV Conference, Buenos Aires, 1991.

Bouzas, Roberto. "Democracia, mercados $Y$ reformas estructurales en América Latina. El contexto económico international." Paper presented at the conference on "Democracy, Markets, and structural Reforms," organized by the North South center/University of Miami and the Fundación Simón Rodríguez, Buenos Aires, 1992.

"United States-Latin American Trade Relations: Issues in the $1980 \mathrm{~s}$ and Prospects for the 1990s". Paper presented at the IPSA XV conference. 
Cameron, David. "Social Democracy, Corporatism, Labor Quiescence, and the Representation of Economic Interest in Advanced Capitalist Society." In John Goldthrope, ed. , Order and Conflict in Contemporary Capitalism. New York: Clarendon Press, 1984.

Canitrot, Osvaldo. "De la derecha externa a la reforma del estado y la liberalización," comments delivered at the conference on "Democracy, Markets, and Structural Reforms."

- "La destrucción del Estado Argentino y los intentos posteriores de reconstrución." Paper presented at the conference on "Democracy, Markets and structural Reforms."

Canitrot, Adolfo and Silvia Sigal. "Interactions Between Market-oriented Reforms and Democratic Consolidation." oversees Development Council. Argentina. First Draft for the Rio Meeting (November 9-10, 1991).

Cardoso, Eliana and Ann Helwege. Latin America's Economy: Diversity. Trends, and Conflicts. Cambridge, Mass.: The MIT Press, 1992 .

Cavarozzi, Marcelo. "Peronism and Radicalism: Argentina's Transition in Perspective." In Elections and Democratization in Latin America. Paul Drake and Eduardo Silvia, eds., San Diego: University of California, 1986.

----. "Beyond Transitions to Democracy in Latin America." Paper presented at the IPSA XV Congress, Buenos Aires, 1991.

- Clase obrera y sindicatos en la Argentina (1955-1973). Buenos Aires: CEDES, 1982.

----. "The Left in Latin America. The Decline of Socialism and the Rise of Political Democracy." Paper presented at the IPSA XV Conference, Buenos Aires, 1991.

Chalmer, Douglas A., Maria do Carmo Campello de Souza and Atilio Borón, eds. The Right and Democracy in Lat in America. New York: Praeger, 1992.

Chen, Linda. "Labor Unions and Regime Transition in Argentina." Ph.D. Dissertation, University of Massachuttes, 1988.

Christian Association of Business. Noticiero Informativo, July 1993. 
clarin, Buenos Aires, Argentina.

Collier, Ruth Berins and David Collier. Shaping the Political Arena. Critical Junctures, the Labor Movement, and Regime Dynamics in Latin America. Princeton: Princeton University Press, 1991.

Conaghan, Catherine, James Malloy and Luis Abugattas. "Business and the Boys: The Politics of Neoliberalism in the Central Andes." LARR 25:3-30.

Consejo Directivo de la confederación General del Trabajo de la República Argentina. Buenos Aires: C.G.T. Press, 1993 .

Córdova, Efrén. "The Informal Challenge." Hemisphere (winter/Spring 1992).

Dávila, Sonia Poblete. "Apuntes para repensar el rol politico de la Central Obrera Boliviana." Paper presented at LASA, September 1992 .

De Bruno, Giselle A. Rapporteur to the International Conference "Democracy, Markets, and structural Reforms in Latin America." Organized by the North-South Center/University of Miami, and the Fundación simón Rodríguez, Buenos Aires, 1992.

Delich, Francisco. "Desmobilización social, reestructuración obrera y cambio sindical." In Peter Waldman and Ernesto Gaizón Valdéz, eds., El poder militar en la Argentina (1976-1981). Buenos Aires: Editorial Galerna, 1983.

De Shazo, Peter. "Workers, Labor Unions, and Industrial Relations in Latin America." LARR 23 (1988):145-56.

De Soto, Hernando. The other Path. The Invisible Revolution in the Third world. London: I.B. Tauris, 1989.

Diamond, Larry, Juan J. Linz, and Seymour Martin Lipset eds., Democracy in Developing Countries: Latin America. Boulder: Lynne Rienner Publishers, 1989.

Di Tella, Torcuato. "Working Class Organization and Politics in Argentina." LARR 16 (1987):101-35.

El nuevo Herald. Miami, Florida.

Epstein, Edward, ed. Labor Autonomy and the state in Latin America. Boston: Unwin Hyman, 1989.

- "Austerity and Trade Unions in Latin America." In william Canak, ed. Lost Promises. Debt, Austerity. 
and Development in Latin America. Boulder: Westview

"Labor-State Conflict in the New Argentine Democracy: Parties, Unions Factions, and Power Maximizing." In Edward Epstein ed., The New Argentine Democracy. The Search for a Successful Formula. Westport: Praeger,

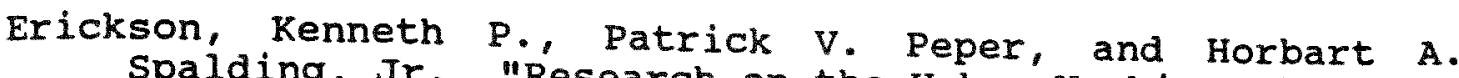
Spalding, Jr. "Research on the Urban Working Class and Organized Labor in Argentina, Brazil, and Chile: What is Left to Be Done?" LARR IX (Summer 1974):115-2.

Espinal, Rosario. "The Right and the New Right in Latin America." Paper presented at the Conference "The Right in Latin America Democracies," Columbia University, New York, 20-21 April, 1990.

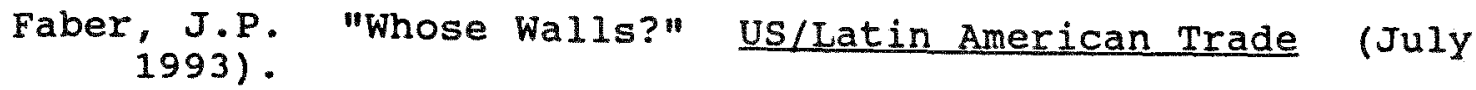

Falcoff, Mark and Ronald Dolkart. prologue to Perón: Argentina in the Depression and War, 1930-1943. Berkeley: University of California Press, 1975.

Fanelli, Jose Maria, Roberto Frenkel, and Guillermo Rosenwurcel, "Growth and Structural Reforms in Latin America. Where we stand?" CEDES, 1991.

Fiorito Jack and Cheryl Maranto. "The Contemporary Decline of Union Strength. "Contemporary Policy Issues. v.5, n 4, 1987 .

French, John. Latin American Labor Studies. An Interim Bibliography of Non-English Publications Miami: FIU, 1989 .

- Latin American Labor studies: A Bibliography of English- Language Publications through 1989. Miami: FIU, 1989 .

Foxley, Alejandro. Latin American Experiments in Neoconservative Economics. Berkeley: University of California Press, 1983.

Gamarra, Eduardo. "Crafting Political support for Stabilization: Political Pacts and the New Economic Policy in Bolivia." Paper presented at the Conference on "Democracy, Markets, and structural Reforms."

- "Bolivia"s Perestroika?" Hemisphere. 2 (Winter/Spring $1990)$. 
- Market oriented Reforms and Democratization in Bolivia. oversees Development Council: forthcoming.

Garretón, Manuel Antonio. "La dimensión politica de los procesos de transformación en Chile." Paper presented at the Conference on "Democracy, Markets, and structural Reforms." Buenos Aires, 1992.

Gillis, Malcom, Dwight H. Perkins, Michael Roemer, and Donald R. Snodgrass, Economics of Development second edition. New York: W., w. Norton \& Company, 1987.

Godio, Julio, Héctor Palomino and Achim Wachenndor. El Movimiento Sindical Argentino 1880-1987. Buenos Aires: Punto Sur, 1988.

Grande, Marla Herminia. CGT. El poder que no fue, 1982-1991. Buenos Aires: Editorial Fundación Ross, n.d.

Haggard, stephan. Pathway to the Periphery: The Politics of Growth in the Newly Industrializing countries. Itaca: Cornell University press, 1990.

Halperín Donghi, Tulio. "Argentina's Unmastered Past." LARR $23(1988): 2-25$.

- "Argentina: Liberalism in a country Born Liberal." In Guiding the Invisible Hand, ed. Joseph Love and Niles Jacobsen. New York: Praeger, 1988.

Heredia, Blanca. "Economic Change and Political order: Governance and Democracy in Mexico." Paper presented at the Conference on "Democracy, Markets, and structural Reforms."

James, Daniel. "Power and Politics in Peronist Trade Unions." Journal of Interamerican studies and World Affairs, 20 , $1978,3-36$.

- "Rationalization and Working Class Response: The Context and Limits of Factory Floor Activity in Argentina." Journal of Latin American Studies 13 (1981):375-402.

- Resistance and Integration. Peronism and the Argentine Working Class, 1946-1976. Cambridge: Cambridge University Press, 1988 .

Juri, Marla de la Esperanza. "Argentina: Privatization of a Government-Owned Winery." Economic Reform Today (Winter 1992).

Khun, Thomas $s$. The structure ok Scientific Revolution. 
Chicago: The University of Chicago Press, 1970.

Korzeniewicz, Roberto P. "The Labour Movement and the state in Argentina, 1887-1907." Bulletin of Latin American Research 8, n.1 (1989): 25-46.

La iniciativa para las Américas, un instrumento de transformación de la región en la década del 90'. La Argentina en su contexto. Buenos Aires: AMCHAM, CARI, CICYP, FIEL, 1991.

La Nación. Buenos Aires, Argentina.

La voz del interior. Córdoba, Argentina.

Landsberger, Henry A. "The Labor Elite: Is it Revolutionary?" in Elites in Latin America. eds., Seymour Martin Lipset and Aldo Solari. New York: oxford University Press, 1967.

Latin American Labor organization. eds., Gerald Michael Greefield and Sheldon L. Maram. New York: Greenwood Press, 1987.

Ley de Asociaciones Sindicales. Ne 23551. Decreto Reglamentario N2467/88.

Levisky, Steve and Tony Lapp. "Solidarismo and organized Labor." Hemisphere (Winter/Spring 1992):26-30.

Lipset, S.M. "Trade Unions and Social structure II." Industrial Relations I 2 (February 1962):90.

Lowenthal, Abraham F., ed., Exporting Democracy: The United States and Latin America. Baltimore: John Hopkins University Press, 1991.

McCamant, John. "Democracy and Domination: Latin America and Eastern Europe." Global Justice 2,n.3. (September/October 1991):1-8.

McGuire, James. "Union political Tactics and Democratic Consolidation in Alfonsin's Argentina, 1983-89." LARR $27,1992,37-74$.

"Political Parties, Social Forces and Democracy in Argentina." Paper presented at the Conference on Parties and Party Systems in Latin America. Kellog Institute for International studies, University of Notre Dame, Notre Dame, Indiana. October, 1990.

Mainwaring, scott. "Political Parties and Democratization in Brazil and the Southern Cone." Comparative Politics 
(October 1988):91-120.

Malloy, James. "The Politics of Transition in Latin America." In Authoritarian and Democrats. In Malloy, James M. and Mitchell A. Selligson, eds., Authoritarians and Democrats. Regime Transition in Latin America. Pittsburg: University of Pittsburg Press, 1987.

Marshall, Adriana. "The Fall of Labor's share in Income and Consumption: A New 'Growth Model' for Argentina?" In William Canak ed., Lost Promises: Debt, Development, and Democracy in Latin America. Boulder: Westview Press, 1989.

Maquiavel10, Niccolo. The Prince. New York: Crofts Inc., 1947.

Marx, Karl. The 18th Brumaire of Louis Bonaparte. New York: International Publishers, 1975.

Montoya, Silvia. "Precarious Employment." Mediterránea Newsletter. córdoba:

Fundacion Mediterránea, 1993.

Fundación

Murmis, Miguel, and Juan Carlos Portiantiero. Estudios sobre los orlqenes del peronismo. Buenos Aires: Siglo XXI, 1971.

Nelson, Joan M. Fragile Coalitions: The Politics of Economic Adjustment. New Brunswick: Transaction Books, 1989.

Newland, Dan. "The Big one." US/Latin Trade (July 1993).

O'Donnel1, Guillermo. Bureaucratic Authoritarianism: Argentina, 1966-1973, in Comparative Perspective. Berkeley: University of California Press, 1988.

- "State Alliances in Argentina, 1956-1976." Journal of Development studies 15 (1978):3-33.

- Modernization and Bureaucratic Authoritarianism: Studies in South America. Berkeley: University of California Press, 1973.

o'Donnell, Guillermo, Philippe c. Schmitter, and Laurence Whitehead, eds., Transitions from Authoritarian Rule: Latin America. Baltimore: The John Hopkins University Press, 1986.

O'Regan, Anthony. "What Has Been Done: The Politics of Organized Labor in Argentina, 1976-1991." Paper presented at the XVII International LASA congress, Los Angeles, California, september 24-27, 1992 . 
Packenham, Robert A. Liberal America and the Third World: Political Development Ideas in Foreign Aid and social Science. Princeton: Princeton University Press, 1973.

Palomino, Héctor. "Argentina las huelgas generales durante la ultima década." Latin American Labor News 4 (1991).

Cambios ocupacionales y sociales en la Argentina. 1971-1985 Buenos Aires: CEDES, 1987.

"El movimiento de democratización sindical," in Elizabeth Jelin, ed., Los nuevos movimientos sociales: Derechos Humanos, obreros, Barrios. Buenos Aires: Centro Editor de América Latina, 1987.

Page, Joseph. Perón: A Bibliography. New York: Random House, 1983.

Palacios, Juan Alberto y Jesús R. Marengo. Reqlamentación del derecho de huelga. Decreto Ne2184/90 y Legislación Complementaria. Antecedentes $y$ comentarios. (Buenos Aires: Valleta Ediciones, 1991).

Peeler, John. Latin American Democracies: Colombia, Costa Rica, and Venezuela. Chapel Hill: The University of North Carolina Press, 1985.

Perea, Mauricio D. Economic Reforms Today. v.2, n.3 (Summer 1992).

Portes, Alejandro and John Walton. Labor, Class, and the International System. New York: Academic Press, 1981.

Ramos, José. Neoconservative Economics in the southern Cone of Latin America. Baltimore: John Hopkins University, 1986 .

Ranis, Peter. Argentine Workers: Peronism and Contemporary class Consciousness. Pittsburgh: University of Pittsburgh Press, 1992.

Régimen de contrato de trabajo. Ley Ne 20.744 reformada por la ley 21.297 actualizada $Y$ concordada con la ley nacional de empleo y ley de accidentes de trabajo.

Remmer, Karen L. "The Politics of Economic Stabilization. IMF Standby Programs in Latin America, 1954-1984," Comparative Politics (October 1986):2-24.

Report on the Americas. "A Market Solution for the Americas?" Published by NACLA XXVI, n.4, February 1993.

Ridde11, Roger. Foreign Aid Reconsidered. Baltimore: John 
Hopkins University Press, 1989.

Ross, Jaime. "On the Political Economy of Markets and state Reform in Mexico." Paper presented at the Conference on "Democracy, Markets, and structural Reforms."

Sachs, Jeffrey. Stabilization." NBER Working Paper Number 2073.

Seligson, Mitchell A. "Democratization in Latin America: The Current Cycle," in Authoritarian and Democrats. Regime Transition in Latin America. eds., James Malloy and Mitchell Seligson. Pittsburgh: University of Pittsburgh Press, 1987.

Selowski, Marcelo. "World Bank Lending for structural Adjustment." Einance and Development (June 1987).

Sheahan, John. Patterns of Development in Lat in America:

Poverty, Repression, and Economic Strategy. Princeton: Princeton University Press, 1987.

Shively, Phillips $w$. The craft of Political Research. New Jersey: Prentice Hall, 1990.

Smith, Tony. "Requiem or New Agenda for Third World studies?" World Politics 37 , Ne4 (July 1985).

Smith, william. "Neoliberal Restructuring and New Democracies in Latin America." North South Issues (May 1992).

- Authoritarianism and the crisis of the Argentine Political Economy. Stanford: standford University Press, 1989 .

- "Restructuring Argentina." Hemisphere (Fal1 1991).

- "State, Market, and Neoliberalism in Post-Transition Argentina. The Menem Experiment." Journal of Interamerican studies and World Affairs (1991).

Smith, William, Carlos Acuña, and Eduardo Gamarra, eds. Democracy, Markets, and structural Adjustment in Latin America. New Brunswick: Transactions, forthcoming.

spalding, Horbart. organized Labor in Latin America: Historical case studies of workers in Dependent Societies. New York: New York University Press, 1977.

Statistical Abstract of Latin America, ed. James w. Wilkie, 1993. 
Stephan, Alfred. Rethinking Military Politics: Brazil and the Southern Cone Princeton: Princeton University Press, 1988 .

"Stephen Fidler on the Impact of a Period of Political Change. Power Shifts to outsider." 14 May 1992, ISLA.

Sullivan, John. "Political Implication of Economic Transition." Paper for the Central and Eastern European Institutes Meeting, International center for Economic Growth, Poland, CIPE, 26 May, 1991.

The International Labor office. "Labor Legislation and Collective Bargaining in the Americas." International Labor Review 84 (July/December, 1961).

The Miami Herald, Miami, Fl.

The white House, office of the Press secretary. Remarks by the President on the Enterprise for the Americas (June 1990).

Tironi, E. and R. Lagos, "Actores sociales y ajuste estructural." Revista de la Cepal no. 44 (Agosto 1991).

Torres, Juan Carlos. "America Latina. Governing Democracies in Hard Times." Paper presented at IPSA XV Congress Section III: The Political correlates of Adjustment Policies.

Trade Unions of the World 1989-1990 2nd. edition. New York: Longman, 1989 .

U.S. Market Access in Latin America: Recent Liberalization Measures and Remaining Barriers. USITC Publication 2521, June 1992.

Vacs, Aldo. "Convergence and Dissension: Democracy, Markets, and Structural Reforms in Global Perspective." Paper presented at the Conference on "Democracy, Markets, and structural Reforms."

- "Authoritarian Breakdown and Redemocratization in Argentina." in Authoritarian and Democrats.

Valenzuela, Samuel J. "Labor Movements in Transitions to Democracy: A Framework for Analysis." Comparative Politics (July 1989).

Walton, John. "Austerity and Labor." Hemisphere. 2 (winter/Spring 1990).

Waissman, Carlos. The Reversal of Development in Argentina. 
Princeton: Princeton University Press, 1987.

Whitehead, Laurence. "On Reform of the state and Regulation of the Market." paper presented at the CEDE Conference on Economic Liberalization and Economic Democratization, Forti, Italy, 1992.

Wiarda, Howards $J$. and Harvey F. Kline, eds. Latin American Politics and Development. Boulder, Co: Westview Press, 1990 .

Yin, Robert $K$. Case Study Research. Design and Methods. Newbury Park, California: Sage Publications, 1989.

Huang, Yukon and Peter Nicholas. "The Social costs of Adjustment. How Adjustment Programs Affect the Poor, and How the World Bank is Helping Ameliorate their Effects," Finance \& Development 24 , no.2 (June 1897).

Zapata, Francisco. "Towards a Latin American Sociology of Labour." Latin American studies 22 (1987):375-402. 


\section{APPENDIX A}

PRINCIPAL ECONOMIC INDICATORS 1989-1992

Macroeconomic Inaicator:

Real GDP Growth :

Consumer Price Inflation

(Annual avg

Current Account $\$ \mathrm{mn}$

Exports FOB $\$ \mathrm{mn}$

$\rightleftarrows$ Imports FOB $\$ \mathrm{mn}$

Net Services

Transfers

Total External Debt $\$$ bn

Real Wages in Manufacturing Sector

collection of Taxes ( $\%$ of GDP)

Fiscal Deficit ( $\%$ of GDP)

$\begin{array}{cc}1989 & 1990 \\ -4.4 & 0.4 \\ 3,079.5 & 2,313.9 \\ -1.307 & 1.903 \\ 9.573 & 12.354 \\ 4.199 & 4.079 \\ -6.687 & -6.443 \\ 8 & 71 \\ 64.3 & 59.8 \\ 82.9 & 78.7 \\ 16.6 & 16.6 \\ 6.1 & 2.0\end{array}$

1991

1992

8.5

6.5

171.7

2.9

$-6.894$

12.550

14.250

$-5.162$

$-6.569$

$-32$

29

61.9

60.0

74.2

74.7

19.1

$24 \cdot 1$

$-0.2$

$-0.6$

Source: Based on data from the BCRA and CEPAL. 